\title{
NEW MONOPHYLETIC BRANCHES OF THE TELOSCHISTACEAE (LICHEN-FORMING ASCOMYCOTA) PROVED BY THREE GENE PHYLOGENY
}

\author{
S. Y. Kondratyuk ${ }^{1,2}$, L. Lőkös ${ }^{3}$, D. K. Upreti ${ }^{4}$, S. Nayaka ${ }^{4}$, G. K. Mishra ${ }^{4}$ \\ S. Ravera ${ }^{5}$, M.-H. JeOnG ${ }^{2}$, S.-H. JANG ${ }^{2}$, J. S. PARK ${ }^{2}$ and J.-S. Hur ${ }^{2}$ \\ ${ }^{1}$ M. H. Kholodny Institute of Botany, Tereshchenkivska str. 2, 01004 Kiev, Ukraine \\ E-mail:ksya_net@ukr.net \\ ${ }^{2}$ Korean Lichen Research Institute, Sunchon National University \\ Sunchon 540-742, Republic of Korea; E-mail: jshur1@sunchon.ac.kr \\ ${ }^{3}$ Department of Botany, Hungarian Natural History Museum \\ H-1431 Budapest, Pf. 137, Hungary; E-mail: lokos.laszlo@nhmus.hu \\ ${ }^{4}$ CSIR-National Botanical Research Institute \\ Rana Pratap Marg, Lucknow-226001 Uttar Pradesh, India; E-mail: upretidknbri@gmail.com \\ ${ }^{5}$ Dipartimento di Bioscienze e Territorio, Università degli Studi del Molise \\ C. da Fonte Lappone, I-86090 Pesche (IS), Italy
}

(Received 10 August, 2016; Accepted 5 December, 2016)

Seventeen robust monophyletic branches newly discovered in the phylogenetic tree of the Teloschistaceae after separate nrITS, nrLSU and mtSSU, as well as combined phylogenetic analysis are proposed to consider as the following separate genera: Dijigiella S. Y. Kondr. et L. Lőkös gen. nov. for the D. kaernefeltiana group, Elixjohnia S. Y. Kondr. et J.-S. Hur gen. nov. for the Sirenophila jackelixii group, Fominiella S. Y. Kondr., D. Upreti et J.-S. Hur gen. nov. for the F. tenerifensis group; Gintarasiella S. Y. Kondr. et J.-S. Hur gen. nov. for Caloplaca aggregata, Hanstrassia S. Y. Kondr. gen. nov. for the Elenkiniana lenae group, Harusavskia S. Y. Kondr. gen. nov. for H. elenkinianoides sp. n., Huriella S. Y. Kondr. et D. Upreti gen. nov. for H. loekoesiana sp. n., Ikaeria S. Y. Kondr., D. Upreti et J.-S. Hur gen. nov. for Caloplaca aurantiellina, Klauderuiella S. Y. Kondr. et J.-S. Hur gen. nov. for the Variospora thallincola group, Laundonia S. Y. Kondr., L. Lőkös et J.-S. Hur gen. nov. for the Gyalolechia flavovirescens group, Lazarenkoiopsis S. Y. Kondr., L. Lőkös et J.-S. Hur gen. nov. for Caloplaca ussuriensis, Nevilleiella S. Y. Kondr. et J.-S. Hur gen. nov. for the Caloplaca marchantii group, Opeltia S. Y. Kondr. et L. Lökös gen. nov. for the Caloplaca neobaltistanica group, Oxneriopsis S. Y. Kondr., D. Upreti et J.-S. Hur gen. nov. for the Caloplaca oxneri group, Teuvoahtiana S. Y. Kondr. et J.-S. Hur gen. nov. for the Caloplaca rugulosa group, Tomnashia S. Y. Kondr. et J.-S. Hur gen. nov. for the Polycauliona rosei group, and Xanthaptychia S. Y. Kondr. et S. Ravera gen. nov. for the Seirophora orientalis group.

Hitherto missing molecular data on three gene sequences of the type species of the genera Seirophora and Sirenophila are completed within this study.

Six new to science species (Dijigiella kaernefeltiana S. Y. Kondr. sp. n., D. subaggregata S. Y. Kondr. et Kärnefelt sp. n., Fominiella tenerifensis S. Y. Kondr., Kärnefelt, A. Thell et T. Feuerer sp. n., Hanstrassia jaeseounhurii S. Y. Kondr., Ch.-H. Park et L. Lőkös sp. n., Harusavskia elenkinianoides S. Y. Kondr., X. Y. Wang, S.-O. Oh et J.-S. Hur sp. n., Huriella loekoesiana S. Y. Kondr. et D. Upreti sp. n.) are described, compared with closely related taxa.

A total of 34 new combinations for genera mentioned above are proposed.

Key words: phylogenetic analysis, phylogenetic tree, Teloschistaceae, three gene phylogeny 


\section{INTRODUCTION}

The taxonomy of the Teloschistaceae has undergone a radical change during recent years, including the creation of a large number of new genera, based mainly on molecular phylogeny (Arup et al. 2013a, Fedorenko et al. 2012, Gaya et al. 2012, Kondratyuk et al. 2013b, 2014a, b, 2015a, c, d, 2016c, d). Hence the number of genera in the Teloschistaceae has increased from 10 in the late 1990s (Kärnefelt 1989) to currently 80 (Arup et al. 2013a, Kondratyuk et al. 2013b, 2014a, c, 2015a, c, $d, 2016 c$, $d$, Søchting et al. 2014a, b), and the family is divided in four subfamilies, Brownlielloideae, Caloplacoideae, Teloschistoideae and Xanthorioideae (Gaya et al. 2012, Arup et al. 2013b, Kondratyuk et al. 2015d).

New data on ITS1/ITS2 nrDNA, 28S nrLSU, and 12S mtSSU sequences for representatives of all four subfamilies of the Teloschistaceae accumulated during 2015 and 2016 were found to illustrate a number of new robust monophyletic branches within the phylogenetic tree of the Teloschistaceae.

The aim of this paper is to provide descriptions of newly discovered robust monophyletic branches, which are supported as separate ITS1/ITS2, nrLSU and mtSSU as combined phylogenetic analysis. Totally 17 robust monophyletic branches newly discovered in the phylogenetic tree of the Teloschistaceae after as separate nrITS, nrLSU and mtSSU, as combined phylogenetic analyses are proposed to consider as separate genera. Descriptions of six new to science species belonging to these genera are provided below, too.

\section{MATERIALS AND METHODS}

More than 1,000 Teloschistaceae specimens, collected in 2014-2016 and deposited in the Korean Lichen Research Institute, Sunchon National University, South Korea (KoLRI), as well as some duplicates in the Hungarian Natural History Museum (BP) and the Lichen Herbarium in the M. H. Kholodny Institute of Botany of National Academy of Sciences of Ukraine (KW-L) have been examined using standard microscopical techniques, and hand-sectioned under a dissecting microscope (Nikon SMZ 645; Nikon, Tokyo, Japan). Anatomical characters were observed using a Nikon Eclipse E200 microscope and a Zeiss Scope, complemented with a digital camera AxioCam ERc 5s. Sections of apothecia were tested with water, K and IKI (10\% potassium iodide).

Total DNA was extracted directly from the thalli according to Ekman (1999) and was purified with DNeasy Plant Mini Kit (QIAGEN, Germany). The nuclear ribosomal RNA gene region including the internal transcribed spacers 1 and 2 and the $5.8 \mathrm{~S}$ subunit (ITS) was amplified using the primers ITS1F (Gardes and Bruns 1993) and ITS4 (White et al. 1990), the 28S LSU using 
the primer LR5 (Vilgalys and Hester 1990), and the $12 \mathrm{~S} \mathrm{mtSSU}$ using the primers mtSSU1-mtSSU3R and mtSSU2R (Fedorenko et al. 2009, 2012).

The amplification was done using a Takara JP/TP600 PCR machine (Takara Bio Inc., Japan). One initial cycle of $5 \mathrm{~min}$ at $94{ }^{\circ} \mathrm{C}$ was followed by 30 cycles of the following steps: 30 seconds at $94{ }^{\circ} \mathrm{C}, 39$ seconds at $57^{\circ} \mathrm{C}$ and $1 \mathrm{~min}$ at $72{ }^{\circ} \mathrm{C}$. Amplifications were ended with a final cycle at $72{ }^{\circ} \mathrm{C}$ for 10 min. PCR products were then sent to the sequencing facilities of the Genotech Cooperation, Seoul, South Korea, for cleaning and sequencing. The sequencing was carried out using the fluorescent marker BigDye and an ABI 3730x1 sequencing machine (Applied Biosystems, Carlsbad, CA, USA).

The consensus sequence was aligned with all related species sequences retrieved from the GenBank database (Appendix). The consensus sequences were then deposited into GenBank under the accession numbers KY614390KY614518. Phylogenetic analysis was performed using the ITS region and LSU gene of nrDNA and 12S SSU mtDNA sequences of 166 fungal taxa retrieved from the GenBank database and the 29 lichen-forming fungi investigated in this study. Sequence alignment was conducted in BioEdit and a phylogenetic tree was generated by the maximum parsimony (MP), minimum evolution (ME), and maximum likelihood (ML) analysis methods. Analyses were conducted using PAUP 4.0b10 on a Macintosh platform (Swofford 2003), and in Mega 5.0 (Tamura et al. 2011) with the number of bootstrap trials set to 1,000.

Our taxon sampling consists of 52 taxa of the Xanthorioideae (Fig. 1), 72 taxa of the Caloplacoideae (Fig. 2), 48 taxa of the Teloschistoideae (Fig. 3) and about 74 taxa of the Browlielloideae (Fig. 4) with Brigantiaea ferruginea as outgroup (Appendix).

Totally 129 sequences on nrDNA and mtDNA are for the first time submitted to GenBank for 58 specimens of 29 taxa.

\section{RESULTS AND DISCUSSIONS}

\section{Current stage of the phylogenetic tree of the Teloschistaceae}

Phylogenetic trees of the teloschistoid, caloplacoid and xanthorioid lichens are presented in Figures 1-3 including respectively members of the subfamilies Teloschistoideae, Caloplacoideae and Xanthorioideae only. In this case all genera, which were described and discussed before, are presented only by type species, while new groups, discussed in this paper are presented by larger number (between three and five) specimens/species.

The aim of the phylogentic tree of the subfamily Brownlielloideae was also to show position of those taxa, which are in somewhat out position to main clades and subphylas of the subfamilies mentioned, while it includes 


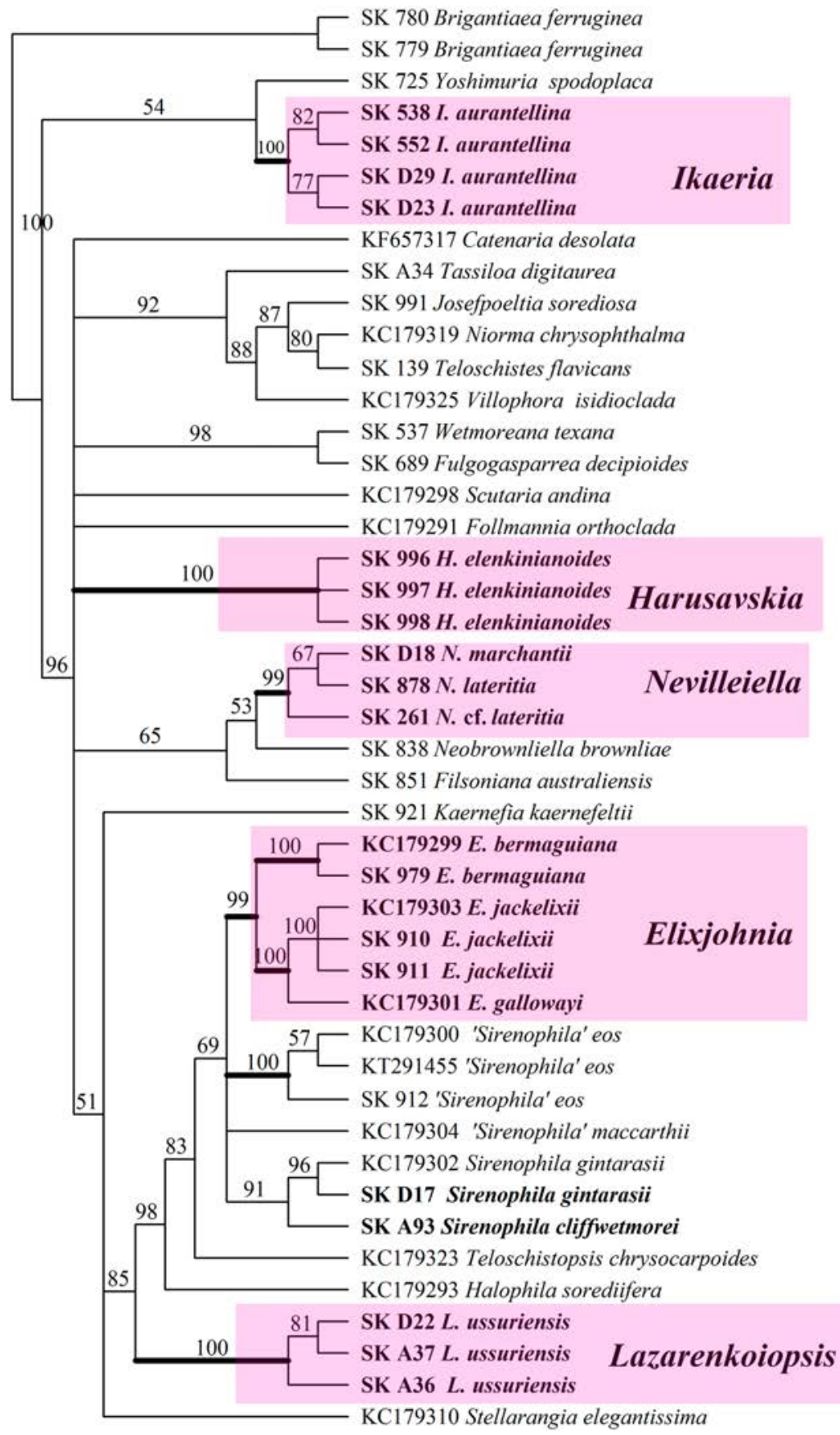

Fig. 1. Phylogenetic analysis of representatives of the subfamily Teloschistoideae after combined data set 


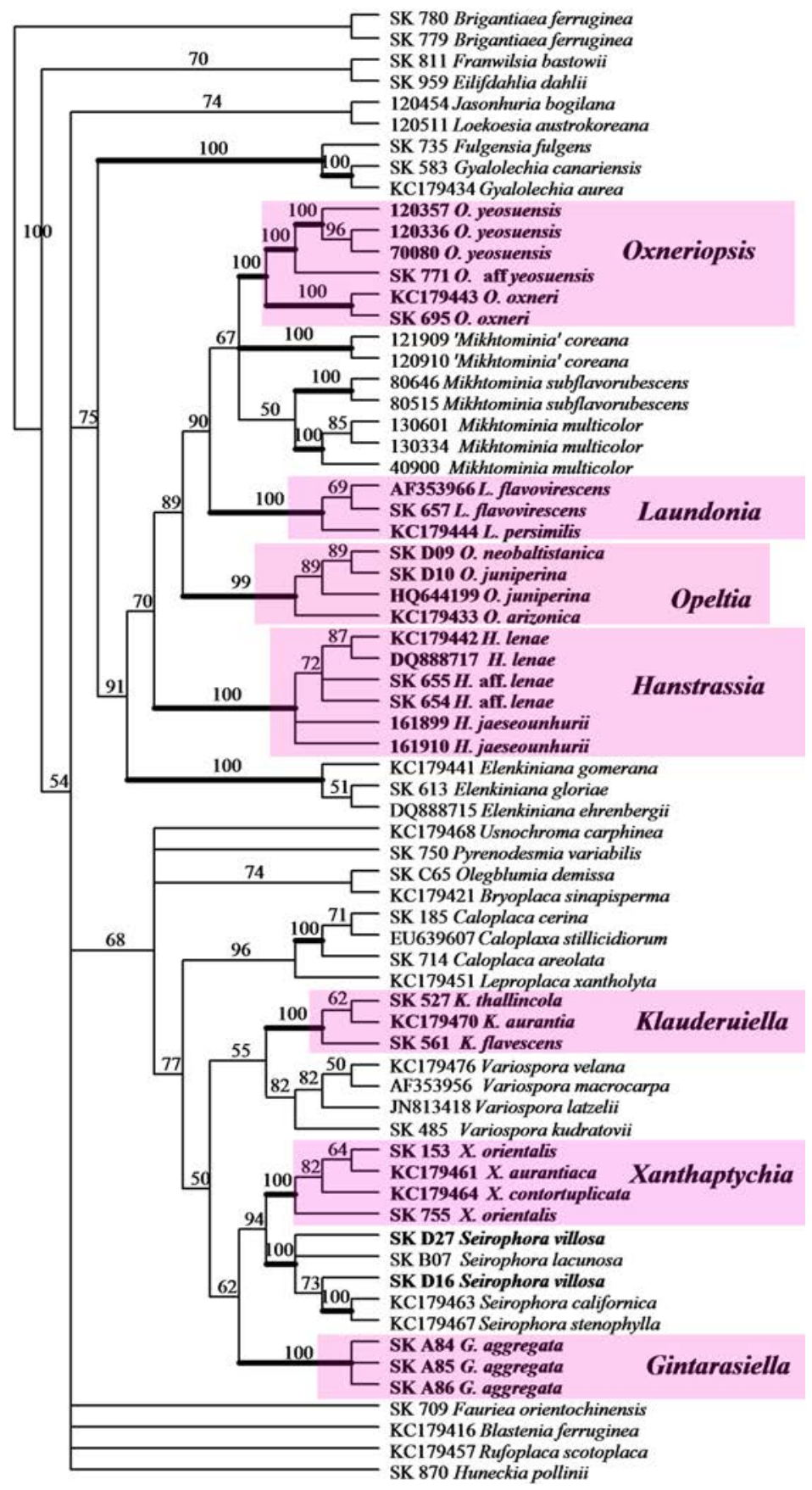

Fig. 2. Phylogenetic analysis of representatives of the subfamily Caloplacoideae after combined data set 
somewhat limited list of taxa of the Xanthorioideae, Caloplacoideae and Teloschistoideae. Main point of that three was to analyse the position of such genera as Franwilsia, Eilifdahlia and Huneckia from the Caloplacoideae, genera Honeggeria, Schackletonia, and Solitaria from the Xanthorioideae and some others being in somewhat out position to subfamilies mentioned.

In general from current phylogenetic tree of the Teloschistaceae we can make conclusion that position of the major part of genera within the subfamilies Teloschistoideae and Xanthorioideae is more or less stable. Only a few new monophyletic branches were added to these subfamilies (i.e. 5 genera to Teloschistoideae and 3 genera to Xanthorioideae).

Twenty-five monophyletic branches of the subfamily Teloschistoideae form single phylum, in which there are the following clades: the Teloschistes s.l. clade with 8 branches, the Follmannia s.l. clade with 4 branches, the Filsoniana s.l. clade with 3 branches, the Sirenophila-Teloschistopsis-Halophila clade with 5 or 6 branches, as well as two genera i.e. Kaernefia and the genus Stellarangia, which are positioning in sister position to the Sirenophila-Teloschistopsis-Halophila clade.

New branches, i.e. the newly proposed genus Ikaeria is positioning in sister position to the genus Yoshimuria in the Teloschistes s.l. clade, the newly proposed genera Harusavskia and Nevilleiella are in the Filsonniana s.l. clade, and two newly proposed genera Elixjohnia and Lazarenkoiopsis are positioned in the Sirenophila-Teloschistopsis-Halophila branch (Fig. 1).

The subfamily Caloplacoideae at current stage includes 2 large subphyla, i.e.: the Gyalolechia s.l. subphylum with 9 monophyletic groups belonging mainly to the Mikhtomia s.l. clade, and genera Jasonhuria, Loekoesia and Gyalolechia s. str. as outgroups to the Mikhtomia s.l. clade, and the Caloplaca s.l. subphylum with 14 monophyletic groups, which mainly belong to the Caloplaca s.l. clade, and three genera, i.e.: Blastenia, Fauriea and Rufoplaca forming the Blastenia s.l. clade.

The genera Huneckia, Franwilsia, and Eilifdahlia are positioned in the out position to the both subphyla of the Caloplacoideae mentioned.

The newly proposed genera Hanstrassia, Laundonia, Opeltia, and Oxneriopsis, are members of the Mikhtomia s.l. clade, while Klauderuiella, Xantaptychia and Gintarasiella - are members of the Caloplaca s.l. clade (Fig. 2).

There are two large subphyla within the subfamily Xanthorioideae (Fig. 3). Eighteen genera/monophyletic groups of this subfamily form the Xanthoria s.l. subphylum among which the genera Flavoplaca and Calogaya are positioned in the outermost position. Seventeen monophyletic groups form the Xanthomendoza s.l. subphylum among which Cerothallia and Austroplaca appeared to be in the outermost position. Additionally to these 35 branches mentioned above the genera Schackletonia and Honeggeria are positioned in out position to both subphyla mentioned above. Level of support of 34 monophyletic branches was discussed before (Kondratyuk et al. 2014c, 2015e). Three 


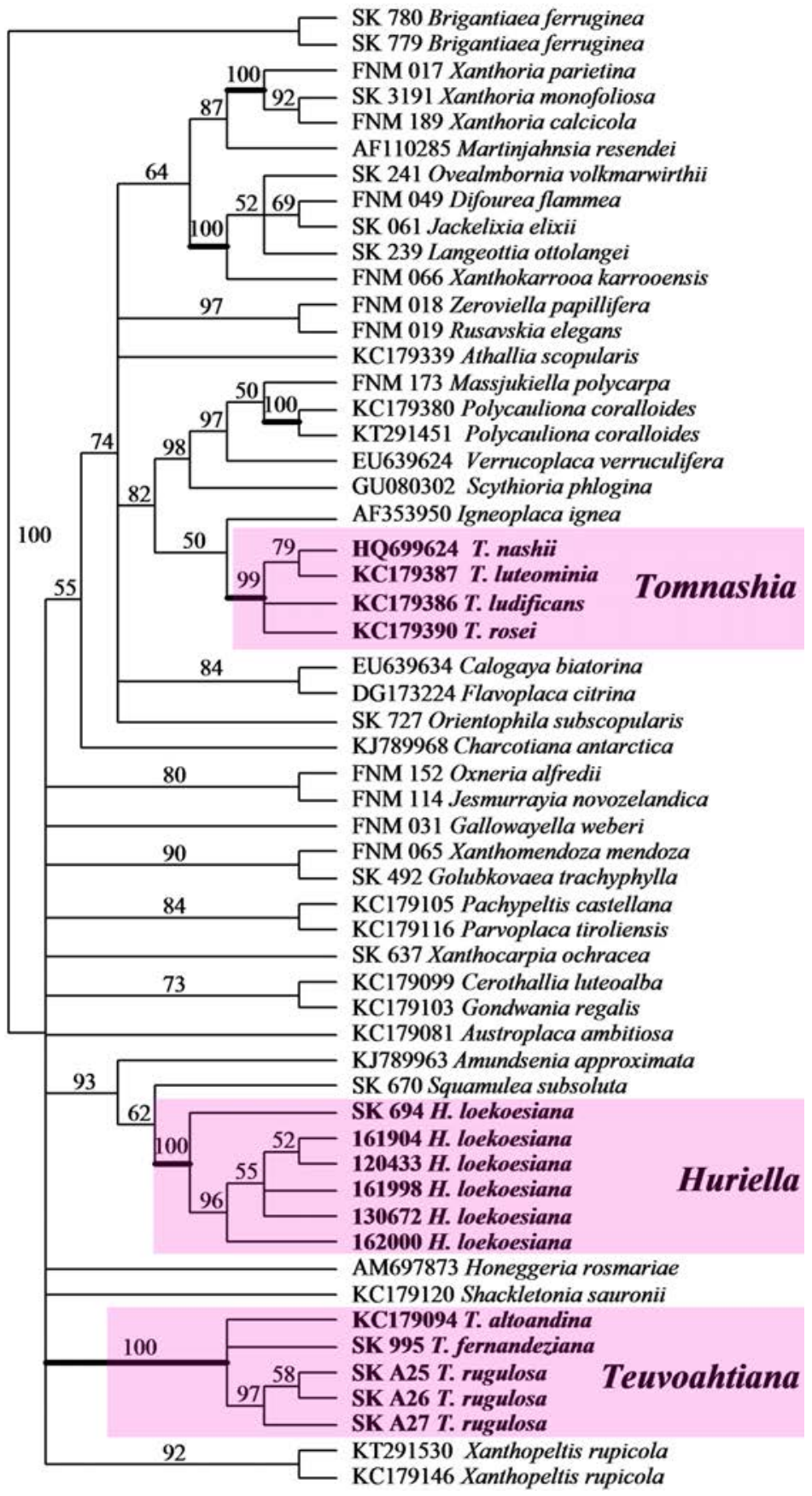

Fig. 3. Phylogenetic analysis of representatives of the subfamily Xanthorioideae after combined data set 


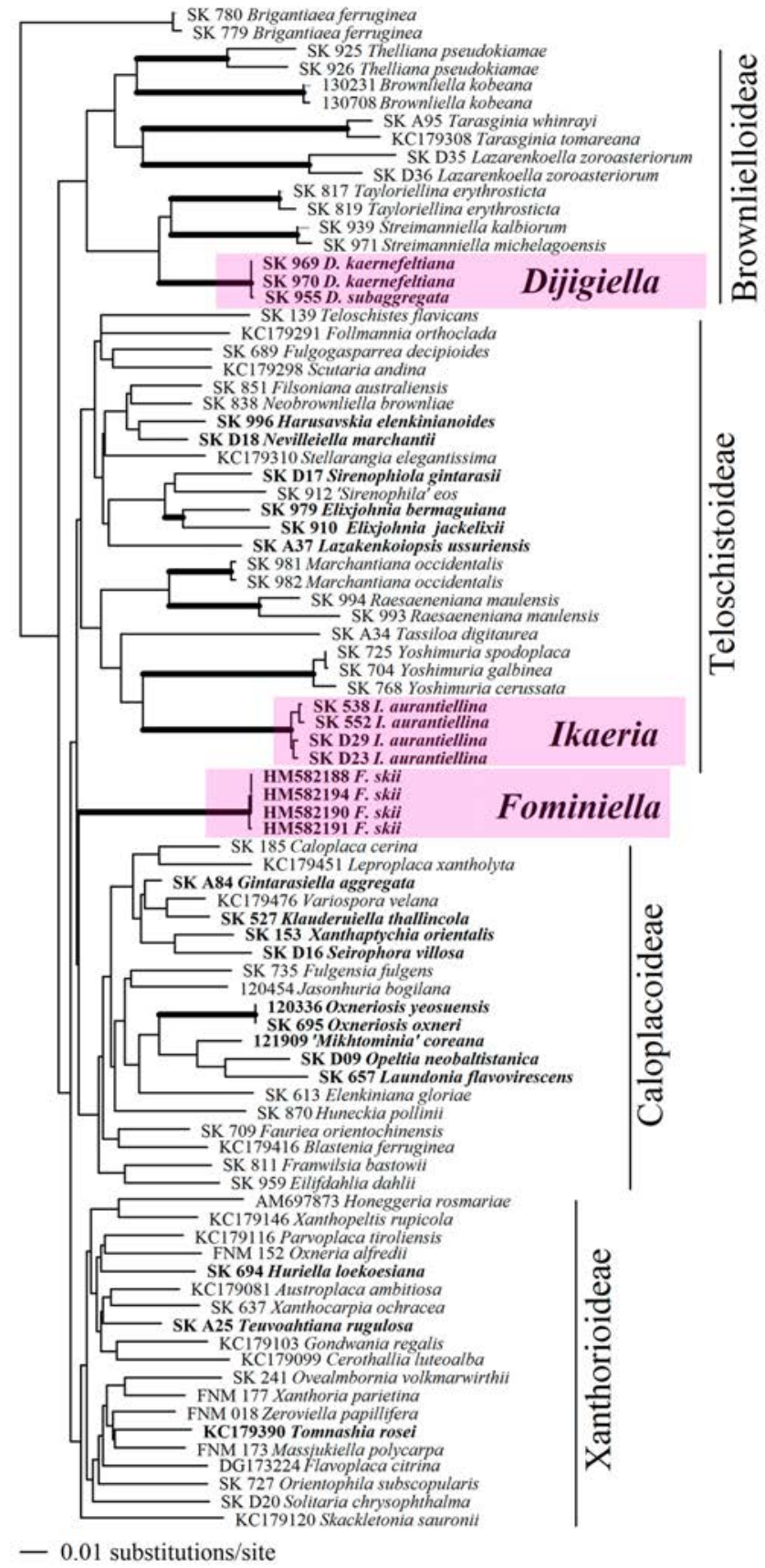

Fig. 4. Phylogenetic analysis of representatives of the subfamily Brownlielloideae after combined data set 
groups, i.e.: Huriella, Teuvoahtiana, and Tomnashia are discussed below (in this paper). Huriella and Teuvoahtiana are members of the Xanthomendoza s.l. subphylum (i.e. of the Xanthomendoza s.l. clade and the Xanthopeltis s.l. clade, respectively), while Tomnashia is a member of the Xanthoria s.l. subphylum and the Polycauliona s.l. clade (Fig. 3).

The most unstable situation is with the subfamilies Brownlielloideae and Caloplacoideae and a number of taxa, which appeared to be in out position to all known subfamilies of the Teloschistaceae. Seven newly proposed genera are added to the subfamily Caloplacoideae (Fig. 3). The subfamily Brownlielloideae itself is almost with the same number of genera as it was in its original description (i.e. only one genus Dijigiella is added) (Fig. 4). However, the level of support of this branch is very low. The genus Ikaeria is positioned within the Caloplacoideae (compare Figs 1 and 4) and the genera Fominiella and Solitaria are in the out position to the subfamily Caloplacoideae, while the genus Solitaria was positioned in the subfamily Xanthorioideae before (Arup et al. 2013a, Kondratyuk et al. 2014c).

The new tendency that the subfamily Brownlielloideae will be divided into two or more separate subphyla with additional new members of this subphylum is found. However, new divisions of the Brownlielloideae can be observed only, when all monophyletic branches of the Teloschistaceae (as well as some still not analysed here) are included into analyses. In such case phylogenetic analysis is becoming more and more time consuming and in need of another computer facilities.

\section{DESCRIPTIONS OF TAXA}

\section{Dijigiella S. Y. Kondr. et L. Lőkös, gen. nov.}

MycoBank nr.: MB 819634.

Similar to the genus Marchantiana of the Teloschistoideae, but differs in positioning in the Brownlielloideae of the Teloschistaceae.

Type species: Dijigiella kaernefeltiana S. Y. Kondr.

Thallus small or indistinct, from endophloedal to corticolous, whitish grey to grey, continuous or more or less cracked to areolate, mainly distinct owing to bright yellow or yellow-orange apothecia, in some taxa densely aggregated in large groups.

Apothecia lecanorine to zeorine or biatorine, disc yellow to yellow-orange, dull brownish yellow to dull yellow-orange; true exciple scleroplectenchymatous or "textura intricata" with matrix to paraplectenchymatous with ma- 
trix, paraphyses broom-like, richly branched in the uppermost portion; asci 8-spored; ascospores bipolar, hyaline.

Ecology: Growing on bark of trees.

Distribution and species content: It hitherto contains two Australian taxa, while several taxa will probably be added in future.

Etymology: It is named after the well-known New Zealand lichenologist David J. Galloway in recognition of his contribution to the lichen flora of the Southern Hemisphere.

Taxonomic notes: After phylogenetic analysis this genus is positioned in the subfamily Brownlielloideae of the Teloschistaceae. From molecular data hitherto available the genus Dijigiella includes two species, i.e. D. kaernefeltiana and D. subaggregata.

A number of sorediate Australian taxa are still in progress of extracting DNA and getting sequences, and hopefully some of them will be added to this genus.

Dijigiella kaernefeltiana S. Y. Kondr., spec. nova (Fig. 5)

MycoBank nr.: MB 819635.

Similar to Marchantiana occidentalis, but differs in having greyish-greenish or greyish-whitish thallus, in having zeorine or lecanorine apothecia with bright orange disc and true exciple, in having scleroplectenchymatous or "textura intricata" true exciple, in having somewhat smaller ascospores, as well as in the lack of ascomatic acid, ascomatatic and 7-0-methylascomatatic acid.

Type: Western Australia: Wicherina, E. of Geraldton, on the road to Mullewa, growing on dry shrubs together with Streimanniella michelagoensis, and species of the genera Caloplaca, Buellia, Teloschistes and Candelariella. Lat.: $28^{\circ} 41^{\prime} 46.0^{\prime \prime}$ S; Long.: 114 56' 40.1" E. Coll.: Kärnefelt, I. (20042002), 07.01.2004 (LD1238056 sub Streimanniella michelagoensis - holotype).

Thallus of very small to $2-3(-5) \mathrm{mm}$ across spots scattered among other lichens, i.e. Streimanniella michelagoensis thalli, greyish-whitish, from very thin consisting of very small $\mathrm{ca} 0.1-0.2 \mathrm{~mm}$ across irregular microareoles to rather thick among apothecia, and with rather larger size of "areoles" to $0.4-0.5 \mathrm{~mm}$ across, and easily distinct owing to bright yellow or yellow-orange discs or own margin of apothecia. Hypothallus not observed.

Apothecia (0.15-)0.3-0.6 mm diam. and to $0.18-0.2 \mathrm{~mm}$ thick in section; lecanorine or zeorine, if lecanorine with grey or grey-greenish thalline margin and yellow-orange or dull yellow-orange disc, if zeorine, own margin concolourous with disc dull yellow-orange observed; usually regularly 

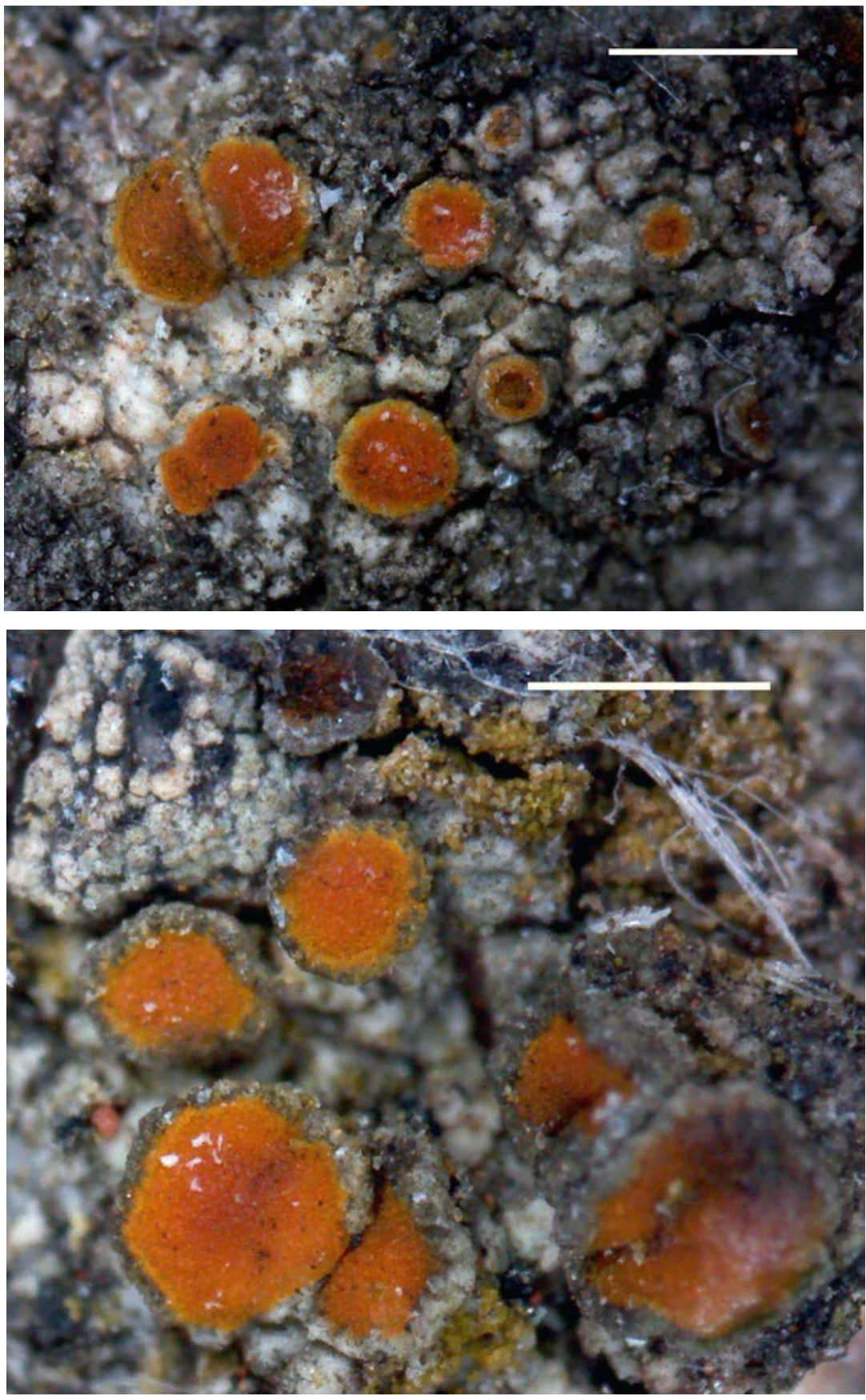

Fig. 5. Dijigiella kaernefeltiana (holotype), general habit. Scale $0.5 \mathrm{~mm}$. (Photo of S. Kondratyuk) 
rounded and distant, rarely aggregated and somewhat irregular, distinctly attenuated at the basis and uplifted above substrate level; in section true exciple to (10-)20-30 $\mu \mathrm{m}$ thick in the uppermost and the lower lateral portions, scleroplectenchymatous or "textura intricata" with matrix and radiating hyphae luminas, (10-)20-30 $\mu \mathrm{m}$ thick in basal portions paraplectenchymatous with matrix(?), cell lumina to $4 \mu \mathrm{m}$ diam. (or cells to $7-9 \mu \mathrm{m}$ across); thalline exciple to $50-70 \mu \mathrm{m}$ thick, cortical layer absent or only of algal plectenchyma; hymenium to 50-60 $\mu \mathrm{m}$ high; paraphyses very richly branched at the tips, broom-like, to 3-4 $\mu \mathrm{m}$ diam. at the tips; subhymenium (50-)70-80 $\mu \mathrm{m}$ thick, straw yellow or to straw-brownish; asci 8-spored, with (2-4-)8 adult bipolar and young ascospores in the same ascus; ascospores bifusiform with somewhat attenuated ends, narrowly ellipsoid, (7.5-)8-13(-14) $\times 4.5-6 \mu \mathrm{m}$ in water, and (7-)8-13(-15) $\times(4-) 5-7(-8) \mu \mathrm{m}$ in $\mathrm{K}$, (in $\mathrm{K}$ becoming more or less widely ellipsoid), ascospores septum (2-)2.5-4 $\mu \mathrm{m}$ wide in water and (2-)3-6 $\mu \mathrm{m}$ wide in $\mathrm{K}$.

Chemistry: Thalline cortical layer and algal plectenchyma of thalline exciple, and epihymenium $\mathrm{K}+$ dirty crimson purple in places.

Etymology: Species is named after the well-known Swedish lichenologist Ingvar Kärnefelt (Lund, Sweden) in recognition of his contribution to lichenology, and who has kindly provided for us an opportunity to participate in a field trip to Australia in 2003-2004 and provided his earlier collections in our disposal.

Distribution: So far known from type locality in Western Australia.

Taxonomic notes: Dijigiella kaernefeltiana is similar to Marchantiana occidentalis (Elix, S. Y. Kondr. et Kärnefelt) S. Y. Kondr., Kärnefelt, A. Thell, Elix, J. Kim, A. S. Kondr. et Hur after having dull greenish-greyish or greenish greyish-whitish thallus, measurements of ascospores and having paraphyses richly branched in the upper portion and densely twisted above asci, but differs in having greyish-greenish or greyish-whitish thallus (vs. brown to dark brown, greenish areoles immersed in bark), and in having zeorine or lecanorine apothecia with bright orange disc and true exciple (vs. biatorine), in having scleroplectenchymatous or "textura intricata" true exciple (vs. pseudoprosoplectenchymatous in lateral portion and paraplectenchymatous in basal portion), as well as in the lack of ascomatic acid, ascomatatic and 7-0-methylascomatatic acid, and in having somewhat shorter ascospores $(8-13 \times 4.5-6$ $\mu \mathrm{m}$ vs. (9-)11-13(-14) × (4-)4.5-6(-7) $\mu \mathrm{m})$.

Dijigiella kaernefeltiana often growing side by side with Streimanniella michelagoensis from which it differs in having lighter and thicker (with somewhat subconvex areoles) thallus (vs. dark brownish-greenish grey to dark brownish grey, smooth or slightly cracked to indistinct), in having much larger and brighter light yellow-orange apothecia $(0.3-0.6 \mathrm{~mm}$ vs. $c a 0.2-0.3 \mathrm{~mm}$ diam., lecanorine apothecia with blackish grey or greenish-greyish brown thalline 
margin and somewhat dull yellow own margin and dull yellowish-blackish or yellowish, bluish-greyish to dull dark brownish orange disc), in having always hyaline ascospores of the same measurements (vs. bipolar ascospores becoming greyish or greyish-blackish at overmature, somewhat similar to Rinodina type ascospores), as well as in the lack of neochloroemodin (see also Kondratyuk et al. 2009). In type collection there is one more crustose member of the Teloschistaceae with rather thick to worthy, grey thallus. Unfortunately it was in insufficient amount for the further study. However, Dijigiella kaernefeltiana differs from this taxon in having lighter brownish-whitish-greyish thallus and in having much brighter dull yellow or dull yellow-orange disc and own margin of apothecia.

Dijigiella kaernefeltiana is similar to 'Caloplaca' ulcerosa Coppins et P. James, but differs in having $\mathrm{K}+$ cortical layer of thallus or thalline exciple and algal plectenchyma in both as well as in the lack of whitish or greyish soredia, and in the lack of pustule-like immersed/ulcer-like soralia. Unfortunately status of 'Caloplaca' ulcerosa is still uncertain from molecular point of view. After ITS phylogeny it is positioned in the Caloplacoideae, but data on nrLSU and $\mathrm{mtSSU}$ are still missing for this taxon.

Dijigiella subaggregata S. Y. Kondr. et Kärnefelt, spec. nova (Fig. 6)

MycoBank nr.: MB 819636.

Similar to Gintarasiella aggregata, but differs in having thinner thallus, in having smaller and plane apothecia, in having hymenium and subhymenium without oil, in having smaller ascospores, in having wider ascospore septum, and in corticolous habit.

Type: Australia: Victoria, Camperdown, in the central part of town, Wpt. 64, on bark of Ulmus, growing together with Caloplaca hanneshertelii, and species of the genera Opegrapha, Hyperphyscia, Phaeophyscia, Lecanora and Physcia. Lat.: $38^{\circ} 14.37^{\prime}$ S; Long.: $143^{\circ} 08.57^{\prime}$ E. Coll.: Kärnefelt, E. I. (996401), 21.01.1999 (LD 1275974 - holotype).

Thallus (0.25-)0.5-1.5(-2.5) cm across, usually indistinct, endophloedal or very thin, whitish or whitish-greyish, well contrasting to darker aggregated apothecia in the centre of thallus, becoming somewhat greyish or dirty white among apothecia or to whitish yellow in peripheral zone probably yellow tinge owing to numerous young apothecia; seen as very dense aggregations of dull yellow or dull brownish yellow apothecia. Hypothallus absent.

Apothecia (0.15-)0.3-0.6 mm diam./across, rather small but easily distinct because often aggregated in very dense aggregations (to 200 apothecia 

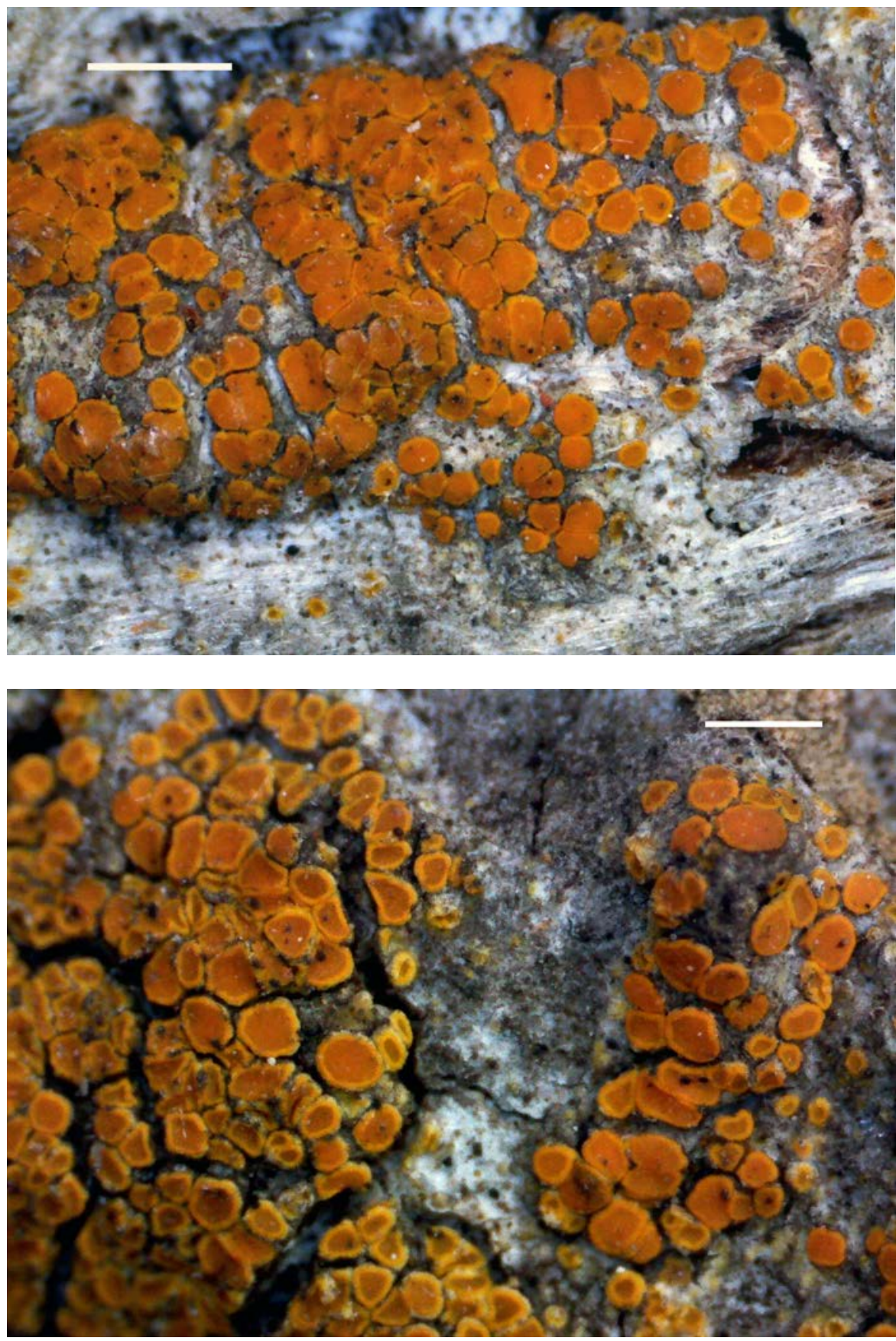

Fig. 6. Dijigiella subaggregata (holotype), general habit. Scale $1 \mathrm{~mm}$. (Photo of S. Kondratyuk) 
per thallus), initially regularly rounded, immersed into substrate, then becoming sessile and aggregated in large aggregations, biatorine with lighter bright or pale yellow own margin to $40(-50) \mu \mathrm{m}$ thick, at initial stages well distinct, somewhat arising disc level, later irregularly developed to disappearing in densely pressed, irregular apothecia; disc more or less plane, dull dark yellow to dull brownish yellow, matt, without pruina; in section biatorine to zeorine, where thalline exciple to $30-40 \mu \mathrm{m}$ thick developed only on underside; true exciple to $20(-40) \mu \mathrm{m}$ thick in the uppermost lateral and to $30 \mu \mathrm{m}$ thick in the lower lateral portion, and not developed or only to $7 \mu \mathrm{m}$ thick in basal portion, more or less paraplectenchymatous; hymenium to 55-60 $\mu \mathrm{m}$ high; epihymenium to $15 \mu \mathrm{m}$ thick, dark orange, paraphyses with 1 or 2 uppermost cells distinctly widened to $3-4(-5) \mu \mathrm{m}$ diam. towards the tips; subhymenium to $20-30(-40) \mu \mathrm{m}$ thick, hyaline, without oil; asci 8 -spored, often very variegating in measurements within the same ascus; ascospores rather small, but with rounded ends, mainly widely ellipsoid, widened at the septum, 7-10(-12) $\times$ $(4-) 5-6(-6.5) \mu \mathrm{m}$ in water and (8-)9-13(-15) × (5-)6-8(-10) $\mu \mathrm{m}$ in $\mathrm{K}$, septum $(2-) 3-4(-4.5) \mu \mathrm{m}$ wide in water and (3-)3.5-5(-7) $\mu \mathrm{m}$ wide in $\mathrm{K}$.

Chemistry: Epihymenium and outer layers of the true exciple $\mathrm{K}+$ crimson purple, somewhat washing out in solution.

Etymology: It is named after similarities to Gintarasiella aggregata.

Distribution: So far known only from type collection, Victoria, southern Australia.

Taxonomic notes: Dijigiella subaggregata is similar to Gintarasiella aggregata, after having thallus dominated almost entirely by clustered apothecia, but differs in having thinner thallus (vs. rather pulvinate), in having smaller and plane apothecia (0.3-0.6 mm vs. $0.3-1 \mathrm{~mm}$ wide, becoming convex in the oldest apothecia), in having hymenium and subhymenium without oil (vs. hymenium and subhymenium especially heavily inspersed with oil droplets or irregular oil aggregations), in having smaller ascospores $(7-10 \times 5-6 \mu \mathrm{m}$ vs. $10-13.5 \times 5-6 \mu \mathrm{m})$, in having wider ascospore septum (3-4 $\mu \mathrm{m}$ vs. $2-3 \mu \mathrm{m}$ wide), and in corticolous habit.

Dijigiella subaggregata is similar to Athallia cerinelloides (Erichsen) Arup, Frödén et Søchting, but differs in having endophloedal or very indistinct thallus (vs. light grey, film-like), in having apothecia densely aggregated in large groups, and in having shorter ascospores $(7-10 \times 5-6 \mu \mathrm{m}$ vs. 9-13 × 5-7 $\mu \mathrm{m})$.

Dijigiella subaggregata is similar to Cerothallia luteoalba (Turner) Arup, Frödén et Søchting, but differs in having wider ascospore septum (3-4 $\mu \mathrm{m}$ vs. $1-1.5 \mu \mathrm{m}$ wide), while ascospores are almost the same $(7-10 \times 5-6 \mu \mathrm{m}$ vs. $8-12 \times 3-6 \mu \mathrm{m})$.

Dijigiella subaggregata is similar to 'Caloplaca' aegatica Giralt, Nimis et Poelt (see also comments below the genus Ikaeria), but differs in having smaller as- 
cospores $(7-10 \times 5-6 \mu \mathrm{m}$ vs. $10-15 \times 7-9 \mu \mathrm{m})$, and narrower ascospore septum (3-4 $\mu \mathrm{m}$ vs. 5-8 $\mu \mathrm{m}$ wide), in having endophloedal thallus (vs. greyish, dirty grey, grey-brown), and in having lighter apothecia (vs. orange to dark orange zeorine, with bright golden margin and disappearing thalline margin).

Dijigiella subaggregata is similar to Fominiella skii (Khodos., Vondrák et Šoun) S. Y. Kondr., D. Upreti et J.-S. Hur, but differs in having lecanorine to zeorine apothecia (vs. zeorine to biatorine) and larger (0.3-0.6 mm vs. $0.2-0.4$ $\mathrm{mm}$ diam.) apothecia, in having smaller ascospores $(7-10 \times 5-6 \mu \mathrm{m}$ vs. $9-11 \times$ $4.5-5.5 \mu \mathrm{m})$ and narrower ascospore septum (3-4 $\mu \mathrm{m}$ vs. $4.5-5.7 \mu \mathrm{m}$ wide), as well as in distribution (vs. the Canary Islands).

Elixjohnia S. Y. Kondr. et J.-S. Hur, gen. nov.

MycoBank nr.: MB 819637.

Similar to genus Sirenophila of the subfamily Teloschistoideae, but forming separate robust monophyletic branch.

Type species: Elixjohnia jackelixii (S. Y. Kondr., Kärnefelt et A. Thell) S. Y. Kondr. et J.-S. Hur.

Thallus distinctly zoned initially with brownish or dirty greenish yellow sterile circles of dull, smooth, continuous peripheral zones or without zonations; usually very thick towards the centre or evenly continuous; smooth and entire or distinctly areolate, whitish, yellowish or greyish to bright red or reddish orange; upper surface cracked and eroded, sometimes with isidia-like structures; medulla often visible through the numerous cracks. Protothallus well developed or absent. Apothecia common, small, zeorine (in some species at least initially), lecanorine or biatorine; disc brownish orange or yellowish brown, with a reddish tinge to dull orange, dark orange-red or scarlet; true exciple scleroplectenchymatous; oil cells in paraphyses of bermaguiana-type (see Kondratyuk et al. 2007, 2009, 2012); asci 8-spored, but 2-4-6 mature bipolar ascospores together with aborted spores often present; ascospores narrowly to broadly ellipsoid; conidia broad ellipsoid to broad bacilliform, (2-)2-3 × 1.2-1.7 $\mu \mathrm{m}$.

Chemistry: It contains parietin (major).

Ecology: Species of the genus grow on exposed coastal rocks (quartzite, granite, basalt and dolerite), at or above the high tide level often together with each other (i.e. E. jackelixii and E. gallowayi often growing side by side), as well as together with species of the genera Tarasginia whinrayi (S. Y. Kondr. et Kärnefelt) S. Y. Kondr., Kärnefelt, A. Thell, Elix, J. Kim, A. S. Kondr. et Hur, T. tomareana (S. Y. Kondr. et Kärnefelt) S. Y. Kondr., Kärnefelt, A. Thell, Elix, J. Kim, A. S. Kondr. et Hur, Sirenophila eos (S. Y. Kondr. et Kärnefelt) Arup, Frödén et Søchting, Jackelixia ligulata (Körb.) S. Y. Kondr., Fedorenko, S. Sten- 
roos, Kärnefelt et A. Thell, Gondwania sublobulata (Nyl.) S. Y. Kondr., Kärnefelt, Elix, A. Thell, J. Kim, M.-H. Jeong, N.-N. Yu, A. S. Kondratiuk et J.-S. Hur, H. cribrosa (Hue) Søchting, Frödén et Arup and Caloplaca conranii S. Y. Kondr. et Kärnefelt.

Distribution: Species of this genus widely distributed in southern and southeastern Australia, Tasmania and New Zealand.

Etymology: Genus is named after the well-known Australian lichenologist and chemist Elix John Alan ('Jack') in recognition of his contribution to lichenology.

Taxonomic notes: After combined phylogenetic analysis the genus Elixjohnia is a member of the large Sirenophila-Teloschistopsis-Halophila subclade of the Teloschistoideae. This branch includes three species, i.e. E. bermaguiana, E. jackelixii and E. gallowayi after molecular data hitherto available.

Since 2013, when genus Sirenophila was described, situation with taxa of this branch has been problematic, because the genus Sirenophila was in fact segregated only on the basis of ITS phylogeny. Only ITS data were provided for the rather rare Australian taxon S. gintarasii (S. Y. Kondr. et Kärnefelt) Arup, Frödén et Søchting (Arup et al. 2013a), type species of the genus Sirenophila.

We were able to get $28 \mathrm{~S}$ nrLSU and $12 \mathrm{~S} \mathrm{mtSSU}$ data for this taxon from isotype kept in KW-L and they are presented here (Appendix).

From phylogenetic analysis (Fig. 1) it is seen that the genus Sirenophila s. str. includes only S. gintarasii and S. cliffwetmorei (S. Y. Kondr. et Kärnefelt) S. Y. Kondr., recently combines to this genus (Kondratyuk et al. 2015e). Status of Sirenophila eos, as well as of $S$. maccarthii is still questionable and should be repeatedly analysed, when more molecular data on this phylum will be available.

Two species of this genus, i.e.: E. jackelixii and E. bermaguiana were compared with Tomnashia rosei (see below), which belongs to the Xanthorioideae. Furthermore E. bermaguiana was compared also with Caloplaca inconnexa (Nyl.) Zahlbr. (supposedly the Xanthorioideae) and Caloplaca nubigena (Kremp.) Dalla Torre et Sarnth. (supposedly Caloplacoideae). Molecular data on Caloplaca inconnexa and C. nubigena are still missing. In original description E. gallowayi was compared only with Sirenophila eos (Kondratyuk et al. 2007).

Fominiella S. Y. Kondr., D. Upreti et J.-S. Hur, gen. nov. MycoBank nr.: MB 819638.

Similar to genera Athallia of the Xanthorioideae, but differs in having different measurements of ascospores as well as in positioning in distant position from the Teloschistoideae, as well as in out position to both subfamilies Caloplacoideae and Teloschistoideae. 
Type species: Fominiella tenerifensis S. Y. Kondr., Kärnefelt, A. Thell et T. Feuerer.

Thallus thin, film-like, inconspicuous, whitish to light grey or pale yellowish. Hypothallus not developed.

Apothecia zeorine to lecanorine or biatorine, disc yellow-orange, own margin yellow, always paler than disc; thalline exciple white, greyish to yellow-white, soon disappearing or permanent, true exciple leptodermatous paraplectenchymatous; asci 8-spored; ascospores polarilocular, hyaline.

Chemistry: Parietin (major), emodin, parietinic acid, fallacinal and teloschistin (trace).

Etymology: This genus is named after the well-known Ukrainian botanist Alexandr Valyljovych Fomin, specialists on cryptogamic plants, who is founder of several botanical institutions and periodicals in Georgia and Ukraine including recent institution known as M. H. Kholodny Institute of Botany, National Academy of Sciences of Ukraine.

Distribution and species diversity: So far genus includes two species, one of which, i.e.: Fominiella skii known from arid and semiarid conditions of southern and southeastern Europe and the Near East of Asia, and the second (F. tenerifensis) is known only from the Canary Islands.

Taxonomic notes and phylogenetic affiliations: After combined phylogenetic analysis the genus Fominiella is positioned in out position to all known subfamilies (Fig. 4). The genus includes two species, i.e.: F. tenerifensis and F. skii after molecular data hitherto available.

In original description (Vondrák et al. 2011) Fominiella skii was already compared with members of the following genera of the subfamily Xanthorioideae, i.e.: Athallia Arup, Frödén et Søchting (i.e.: A. cerinelloides (Erichsen) Arup, Frödén et Søchting), and Xanthocarpia (i.e.: X. raesaenenii (Bredkina) S. Y. Kondr.), with which it is similar in having very reduced thallus. Reduction of the thallus has occurred independently several times in the evolution of the Teloschistaceae (Kärnefelt 1989; Vondrák et al. 2011).

On the basis of ITS phylogeny Fominiella skii was also included into the genus Athallia (Arup et al. 2013a). However, providing data on nrLSU and $\mathrm{mtSSU}$ has allowed showing its positioning in rather distant position from Xanthorioideae and being in somewhat out position to both subfamilies Caloplacoideae and Teloschistoideae.

ITS sequence of the type specimen of Fominiella skii (HM582191) provided in original paper (Vondrák et al. 2011) is included into analysis. However, 28S nr LSU and $12 S \mathrm{mtSSU}$ were obtained from material of F. tenerifensis within this study only. Unfortunately we were not able to get ITS data on material investigated, while a number of special attempts were done. So this genus is in 
urgent need of confirmation by molecular data (data on three or more genes) obtained from the same specimen (of the same species).

Fominiella tenerifensis S. Y. Kondr., Kärnefelt, A. Thell et T. Feuerer, spec. nova

MycoBank nr.: MB 819639.

Similar to Fominiella skii, but differs in having well-developed thalline exciple, in having longer and wider ascospores, and in the lack of true exciple in lateral portion.

Type: Spain, Canary Islands, Tenerife Island, Santiago del Teide, on bark of Spartocytisus shrubs. Lat.: $28^{\circ} 17.631^{\prime}$ N; Long.: $16^{\circ} 48.989^{\prime}$ W. Alt.: $920 \mathrm{~m}$ a.s.l. Coll.: Kondratyuk, S. Y. (20917), 15.01.2009 (KW-L - holotype, LD, BP, B - isotypes).

Thallus thin, film-like, inconspicuous or visible only around apothecia, whitish, light grey or pale yellowish. Hypothallus not developed.

Apothecia $0.2-0.35 \mathrm{~mm}$ diam. and to $0.12 \mathrm{~mm}$ thick in section, lecanorine, very small and usually aggregated in groups, true exciple not present in the uppermost lateral and lower lateral portions, to $10-15 \mu \mathrm{m}$ thick in basal portion, leptodermatous paraplectenchymatous, cell lumina 3-5 $\mu \mathrm{m}$ diam./ across; thalline exciple 50-60 $\mu \mathrm{m}$ thick with cortical layer to 15-20 $\mu \mathrm{m}$ thick, paraplectenchymatous, K-; hymenium $70 \mu \mathrm{m}$ high; epihymenium $\mathrm{K}+$ purple; paraphyses almost not widened towards the tips, with uppermost cells to 3-3.5 $\mu \mathrm{m}$ diam. in water (and to $2-3 \mu \mathrm{m}$ diam. in $\mathrm{K}$ ), richly broom-like branched (better seen in K), with oil droplets, but very indistinct or badly seen owing to small measurements, to $2-3 \mu \mathrm{m}$ diam. (better seen in K); subhymenium 20-30 $\mu \mathrm{m}$ thick; asci 8-spored; ascospores elongated ellipsoid, 12-13(-15) $\times(5.5-) 6-7 \mu \mathrm{m}$ in water and 12-14(-15) $\times(5-) 6-7 \mu \mathrm{m}$ in K; septum 5-6(-7) $\mu \mathrm{m}$ wide in water and (6-)7-8 $\mu \mathrm{m}$ wide in $\mathrm{K}$.

Chemistry: Epihymenium and outermost portions of true exciple $\mathrm{K}+$ purple.

Ecology: It grows on barks of twigs of shrubs often associated with Ikaeria aurantiellina.

Etymology: It is named after type collection, Tenerife Island of Spanish Canary Islands.

Distribution: It is so far known from several places within the same Tenerife Island, Spain, Canary Islands.

Taxonomic notes: Fominiella tenerifensis is similar to $F$. skii, but differs in having well-developed thalline exciple, in having longer and wider ascospores $(12-13(-15) \times(5.5-) 6-7 \mu \mathrm{m}$ vs. $(7.5-) 9-11(-12.8) \times(3.5-) 4.6-5.9(-6.5)$ 
$\mu \mathrm{m})$ (while septum is almost the same (5-6(-7) $\mu \mathrm{m}$ vs. (3.5-)4.3-5.7(-6.5) $\mu \mathrm{m})$ ), and in the lack of true exciple in lateral portion.

Fominiella tenerifensis is similar to Athallia cerinelloides (Erichsen) Arup, Frödén et Søchting, but differs in having wider ascospore septum (5-6(-7) $\mu \mathrm{m}$ vs. $3-4 \mu \mathrm{m}$ wide), while ascospores are almost the same $(12-13(-15) \times$ (5.5-)6-7 $\mu \mathrm{m}$ vs. $9-13 \times 5-7 \mu \mathrm{m})$.

Gintarasiella S. Y. Kondr. et J.-S. Hur, gen. nov.

MycoBank nr.: MB 819640.

The genus is characterised by a unique combination of the following characters among representatives of the subfamily Teloschistoideae, i.e.: pulvinate habit, with densely clustered apothecia that essentially obscure the thallus, a very densely inspersed hymenium and subhymenium and relatively small ascospores.

Type species: Gintarasiella aggregata (Kantvilas et S. Y. Kondr.) S. Y. Kondr. et J.-S. Hur.

Thallus crustose, areolate, forming pulvinate patches, dominated almost entirely by clustered apothecia, yellow-orange. Apothecia from zeorine to biatorine, disc deep orange, somewhat darker than thallus, own margin concolourous with disc; true exciple paraplectenchymatous in basal portion and composed of radiating more or less parallel hyphae in the lateral portions; hymenium and subhymenium heavily inspersed with oil droplets or irregular oil aggregations; asci 8-spored; ascospores polarilocular, ellipsoid, hyaline. Conidiomata and conidia not observed.

Chemistry: Thallus and all elements of apothecia $\mathrm{K}+$ crimson purple.

Etymology: This genus is named after our friend and colleague, Dr Gintaras Kantvilas (Hobart, Tasmania), in acknowledgement of his enormous contributions to the taxonomy of the Tasmanian and Australian lichens, especially.

Distribution and species diversity: So far the genus includes only type species, which known from limestone outcrops of Kangaroo Island, Southern Australia.

Taxonomic notes and phylogenetic affiliations: After separate and combined phylogenetic analysis the genus Gintarasiella belongs to the subfamily Teloschistoideae, where it forms separate robust branch within the Sirenophila-Teloschistopsis-Halophila subphylum as the most separate outgroup to this subphylum. From molecular data hitherto available the genus Gintarasiella includes only type species G. aggregata.

In original description the type species of this monotypic genus was already compared with members of the following genera of the subfam- 
ily Xanthorioideae, i.e.: Flavoplaca (i.e.: F. mereschkowskiana (S. Y. Kondr. et Kärnefelt) Arup, Frödén et Søchting), Cerothallia (i.e. C. yorkensis (S. Y. Kondr. et Kärnefelt) Arup, Frödén et Søchting), and Xanthocarpia (i.e.: X. jerramungupensis (S. Y. Kondr., Kärnefelt et Elix) S. Y. Kondr., Kärnefelt, A. Thell, Elix, J. Kim, A. S. Kondr. et J.-S. Hur) (Kantvilas 2016).

From morphological point of view after having inspersed hymenium and subhymenium it can be also compared with the members of the genus Franwilsia (subfamily Caloplacoideae), as well as after having pulvinate thallus with some Calogaya species (i.e. C. lobulata (Flörke) Arup, Frödén et Søchting known from bark of introduced trees in Tasmania) of the Xanthorioideae. However, it differs in having smaller ascospores and different chemistry, as well as in the positioning in the subfamily Teloschistoideae of the Teloschistaceae.

\section{Hanstrassia S. Y. Kondr., gen. nov.}

MycoBank nr.: MB 819641.

Similar to genus Elenkiniana, but differs in having mainly areolate and sorediate thallus, and in positioning in separate robust monophyletic branch within the Mikhtomia s.l. clade of the Caloplacoideae.

Type species: Hanstrassia lenae (Søchting et G. Figueras) S. Y. Kondr.

Thallus saxicolous or terricolous, areolate, effigurate or only weakly lobate at the margin, yellowish grey, pale yellow, ochre to orange or brownish yellow, often with a whitish pruina; areoles thick; soralia scarce or numerous, labriform, usually marginal, yellowish to ochre, usually brighter than the thallus; cortical layer pseudoprosoplectenchymatous or scleroplectenchymatous; medulla dense, consisting of interwoven hyphae, without a clear orientation.

Apothecia lecanorine to zeorine, few and dispersed; disc flat, later sometimes rather convex, deep orange to brownish, sometimes with whitish pruina at initial stages; true exciple prosoplectenchymatous; asci 8-spored; ascospores polarilocular. Conidia bacilliform, 3-3.5 × 1-1.25 $\mu \mathrm{m}$.

Chemistry: Anthraquinone fragilin and depsidones caloploicin and vicanicin (major), and anthraquinones parietin, emodin, and depsidone isofulgidin in small concentrations.

Ecology: It grows on limestone and calcareous schist of vertical cliffs in dry continental conditions or on sandy soil in mountainous deserts of the Asian continent.

Etymology: It is named after the well-known Estonian lichenologist Hans Trass (02.05.1928-14.02.2017) in recognition of his contribution to lichenology and to geobotany, as well as for his contribution to Eurasian lichen flora. 
Distribution and species diversity: Type species Hanstrassia lenae is known from northeastern Asia from the Altai Region in Siberia and the Mongolian People's Republic to Yakutia, while H. jaeseounhurii described here is so far known only from the type locality of China. Taxonomic status of material previously identified as $H$. lenae from Russia is in need of further clarifying.

Taxonomic notes and phylogenetic affinities: After combined phylogenetic analysis the genus Hanstrassia is positioned in separate robust monophyletic branch within the Mikhtomia s.l. branch, while after ITS phylogeny it was placed in the genus Gyalolechia s.l. (Arup et al. 2013a), and to the genus Elenkiniana (Kondratyuk et al. 2014c).

It is interesting to note, that in the first ITS phylogenetic tree published in the paper with original description of $H$. lenae it was positioned in sister position to the Laundonia flavovirescens (Søchting and Figueras 2007), and now the same position is confirmed by three gene phylogeny (Fig. 2).

Hanstrassia jaeseounhurii S. Y. Kondr., Ch.-H. Park et L. Lőkös, spec. nova (Figs 7-8)

MycoBank nr.: MB 819642.

Similar to Hanstrassia lenae, but differs in having much larger thalline areoles, in having only areolate thallus, in having very scarce soredia and in having scleroplectenchymatous cortical layer of thallus.

Type: China. Qinghai Province, between Jingtai and Zhongwei (close to Yellow River), along 201 Provincial Road, on soil, growing together with Candelariella sp. Lat.: $37^{\circ} 25^{\prime} 19.78^{\prime \prime} \mathrm{N}$; Long.: $104^{\circ} 34^{\prime} 50.05^{\prime \prime} \mathrm{E}$; Alt.: 1,686 m a.s.l. Coll.: Hur, J.-S. and Park, Ch.-H. (CH 160016), 17.06.2016 (KoLRI 041972 - holotype); the same locality and collectors, on soil, growing together with Candelariella sp., Megaspora sp. and Catapyrenium sp. (CH 160015) (KoLRI 041972 sub Candelariella - isotype).

Thallus to 2-3(-5) cm across, distinctly areolate, without lobes in peripheral position, brownish green-yellow, with whitish pruina towards the peripheral portion; areoles distant, scattered and regularly rounded, to (0.2-)0.5-1 $\mathrm{mm}$ diam./across in peripheral portion, and much larger to $(0.5-) 1-3(-4) \mathrm{mm}$ across, in the centre, seem to be overlapping by marginal portions; sorediate. In section thalline areoles (0.3-)0.4-0.8 mm thick, while together with slightly brownish medullar layer (may be including overgrowing old portions?) to 1-1.6 mm thick; cortical layer 50-75(-100) $\mu \mathrm{m}$ thick, yellowish in upper portion or throughout, scleroplectenchymatous, cell lumina to $3-4(-5) \mu \mathrm{m}$ diam., often with oxalate crystals to $(5-) 7-15(-20)[-40] \mu \mathrm{m}$ across; $\mathrm{K}+$ purple, while 

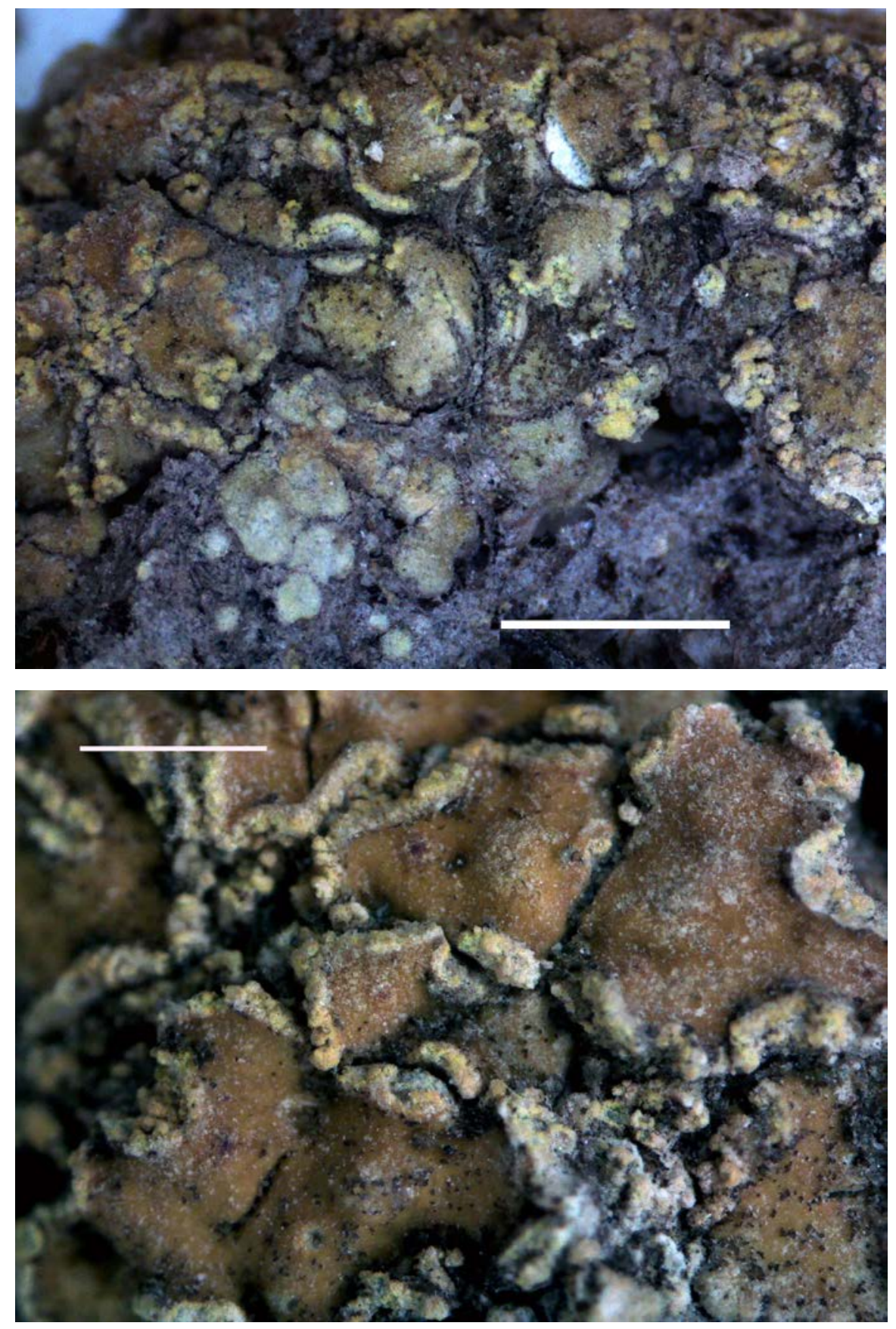

Fig. 7. Hanstrassia jaeseounhurii (holotype), general habit. Scale $2 \mathrm{~mm}$ (top) and $1 \mathrm{~mm}$ (bottom). (Photo of S. Kondratyuk) 
portions with crystals $\mathrm{K}+$ blackish purple in places; epinecral portions (better seen in $\mathrm{K}$ ) to $20(-25) \mu \mathrm{m}$ thick, in places dirty brownish; algal layer 50-70 $(-150) \mu \mathrm{m}$ thick, in places consisting of clusters, not entire, algal cells to 10 $22.5 \mu \mathrm{m}$ diam./ across; medulla white, compact (without hollows) to 0.4-1.4 $\mathrm{mm}$ thick, where upper portion to $0.4-0.5 \mathrm{~mm}$ thick below algal layer purely white, while lower portion (to $0.7-1 \mathrm{~mm}$ thick) straw yellowish or somewhat pale brownish, probably owing to dust/soil particles, usually hardly seen, owing to numerous crystals not dissolving in K. Soralia marginal, somewhat liplike; soredia/schizidia usually rather scarce, 0.06-0.12(-0.2) mm diam./across, or rarely in larger aggregations, irregular, light yellow or lemon yellow (well contrasting to darker thallus). Apothecia, conidiomata, and conidia unknown.

Chemistry: Cortical layer of thallus $\mathrm{K}+$ purple, while portions with numerous crystals $\mathrm{K}+$ to blackish purple in places.

Ecology: Growing on soil among mosses and together with species of the genera Candelariella, Placopyrenium, Collema and Megaspora.

Etymology: It is named after Prof. Jae-Seoun Hur (Suncheon, Republic of Korea), who has collected the type material and has kindly provided it for our study.

Distribution: So far known only from the type locality in Inner Mongolia, Northern China, Asia.

Taxonomic notes: Hanstrassia jaeseounhurii is similar to $H$. lenae, but differs in having much larger thalline areoles (1-3(-4) $\mathrm{mm}$ vs. ca $1 \mathrm{~mm}$ diam./across), in having only areolate thallus (vs. sometimes slightly radially elongated at the periphery of the thallus and narrower, i.e. thallus is effigurate, but only weakly lobate at the margin), in having very scarce and much larger $(0.06-0.12(-0.2)$ $\mathrm{mm}$ diam./across vs. $25-40(-50) \mu \mathrm{m}$ diam.) soredia and in having scleroplectenchymatous (vs. prosoplectenchymatous) cortical layer of thallus.

Hanstrassia jaeseounhurii is similar to Fulgensia desertorum (Tomin) Poelt in having schizidia and crustose thallus often dispersed into elements, but differs in having distinctly areolate (vs. continuous crustose) and larger (2-3(-5) $\mathrm{cm}$ vs. $0.75-1.6 \mathrm{~cm}$ across) thallus, in having larger thalline areoles $(1-3(-4)$ $\mathrm{mm}$ vs. $0.4-0.7 \mathrm{~mm}$ across), in the lack of lobate peripheral portion, in having much thicker cortical layer, in having distinct algal zone and medulla, as well as in positioning in separate monophyletic branch (vs. it is positioned in the Gyalolechia s.l. clade).

After lack of apothecia and non-lobate peripheral portion, and more or less warty squamulose thallus Hanstrassia jaeseounhurii is similar to Fulgensia bracteata subsp. deformis (Erichsen) Poelt, but differs in having distinctly areolate thallus (vs. warty crustose to squamulose), in having much larger areoles $(1-3(-4) \mathrm{mm}$ vs. only in peripheral zone distinct as ca $0.2-0.5 \mathrm{~mm}$ across), and in having scarce and smaller $(0.06-0.12(-0.2) \mathrm{mm}$ vs. $0.2-0.4 \mathrm{~mm}$ across $)$ schizidia. 

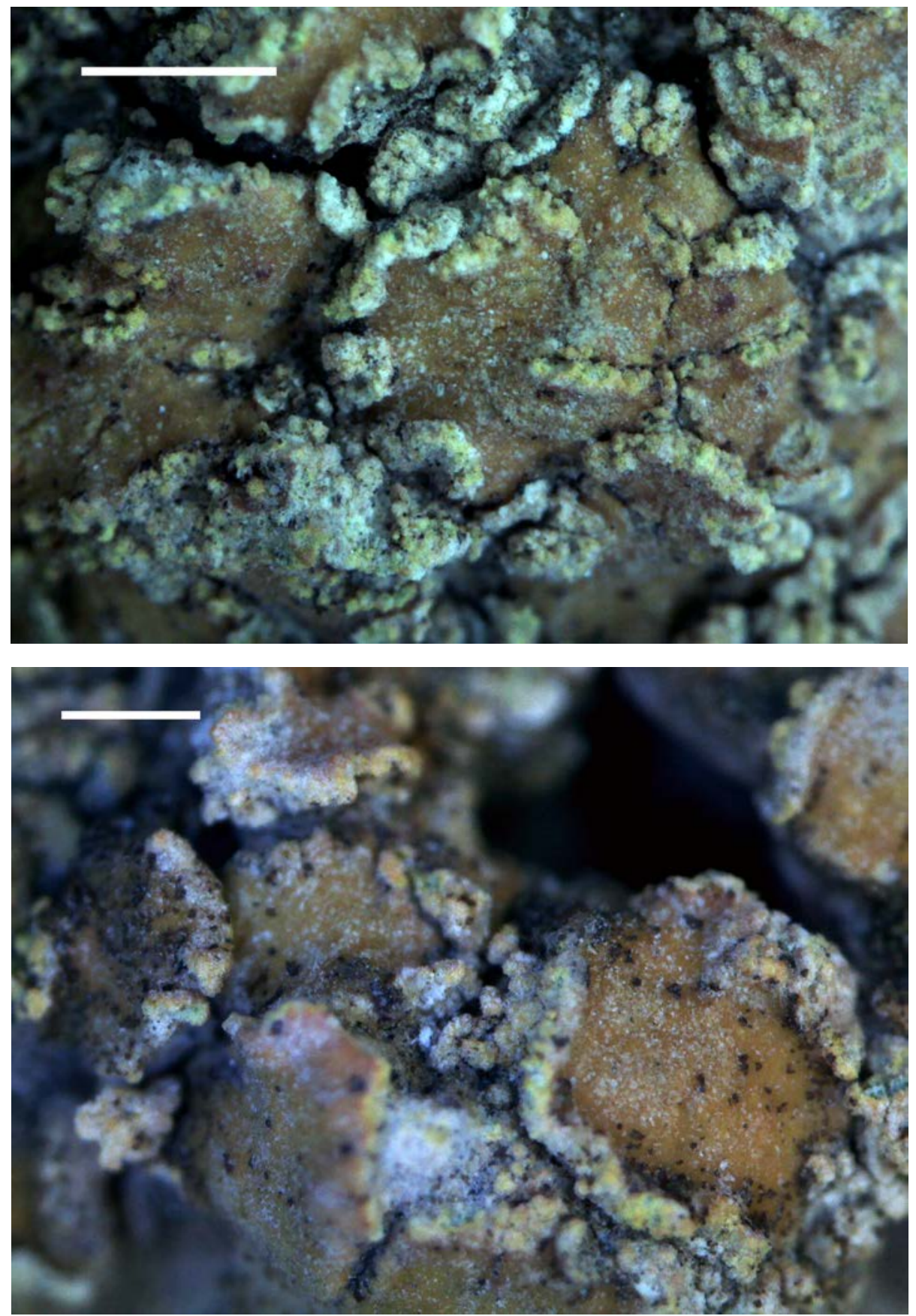

Fig. 8. Hanstrassia jaeseounhurii (holotype), enlarged portions with scarce schizidia. Scale 1 $\mathrm{mm}$ (top) and $0.5 \mathrm{~mm}$ (bottom). (Photo of S. Kondratyuk) 
After having naked medulla in marginal soralia Hanstrassia jaeseounhurii is similar to Megaspora rimisorediata Valadbeigi et A. Nordin, growing on calcareous soil in desert conditions of Eurasia, but differs in having brownish green-yellow (vs. whitish or white grey) thallus and in having much larger (0.06-0.12(-0.2) $\mathrm{mm}$ vs. 0.05-0.07 $\mathrm{mm}$ ) and lemon yellow (vs. blackish or bluish grey) soredia, as well as in having bright yellow medulla in naked portions (vs. medulla white).

Harusavskia S. Y. Kondr., gen. nov.

MycoBank nr.: MB 819643.

Similar to the genus Rusavskia, but differs in being distinctly areolate in the centre of the thallus, in the lack of lower cortical layer, in having narrower thalline lobes, in having ascospores with halo and in having very indistinct ascospore septum.

Type species: Harusavskia elenkinianoides S. Y. Kondr., X. Y. Wang, S.-O. Oh et J.-S. Hur.

Thallus areolate in the centre and distinctly lobate, with well-developed lobes within peripheral zone; yellow-brownish orange to brownish yelloworange in peripheral portions matt or somewhat shiny with rather scarce pseudocyphellae, while in the centre pseudocyphellae numerous forming eroded upper surface, whitish-brownish yellow-orange.

Apothecia lecanorine, where thalline exciple yellowish-brownish orange and disc mainly plane, dark brownish brick-orange; true exciple "textura intricata" or "textura globosa", with very thin cell walls; cortical layer of thalline exciple paraplectenchymatous; subhymenium with numerous oil droplets; asci 8-spored; ascospores seem to be simple, septum mainly not developed (not seen in water) or only juvenile stage of septum seen, with well distinct halo to 1-1.2(-1.5) $\mu \mathrm{m}$ wide in $\mathrm{K}$.

Chemistry: Thallus $\mathrm{K}+$ purple. Epihymenium and cortical layer of thalline exciple $\mathrm{K}+$ bright crimson purple washing in liquid; cortex of thalline section $\mathrm{K}+$ bluish, violet- or ink-purple.

Ecology: Growing on siliceous rock.

Distribution: So far known only from the type locality in Chile, South America.

Etymology: Genus Harusavskia named after ascospores having "halo", and after similarities with Rusavskia elegans, to which this material was originally included.

Taxonomic notes and phylogenetic affiliations: After combined phylogenetic tree this unique monotypic genus is positioned within the Filsoniana 
clade of the subfamily Teloschistoideae (Fig. 1). From all representatives of the Teloschistaceae this genus differs in having ascospores with halo.

\section{Harusavskia elenkinianoides S. Y. Kondr., X. Y. Wang, S.-O. Oh et J.-S. Hur, spec. nova}

(Fig. 9)

MycoBank nr.: MB 819644.

Similar to Elenkiniana gomerana, but differs in having shorter and much wider thalline lobes, in having somewhat larger apothecia with lower cortical layer, in having much thicker true exciple especially in basal portion, and in having "textura intricata" or "textura globosa" of true exciple, in having higher hymenium, in having larger ascospores, and in having narrower ascospore septum, as well as in having ascospores with halo.

Type: Chile. 'Laguna del Maule', Maule, on rock. Lat.: 35 57' 25.0” S; Long.: 70 34' 23.9" W; Alt.: ca 1,887 m alt. Coll.: Wang, X. Y., Oh, S.-O. and Hur, J.-S. (CL 120324), 30.01.2012 (KoLRI 014493 - holotype).

Thallus to several $\mathrm{cm}$ across, areolate in the centre and distinctly lobate, with well-developed lobes within peripheral zone to $2.5-3.5 \mathrm{~mm}$ wide; central portions more or less evenly areolate, areoles $0.4-0.8 \mathrm{~mm}$ across and to $0.2-0.3 \mathrm{~mm}$ thick, irregular; lobes to $2-3.5 \mathrm{~mm}$ long and (0.4-) $0.8-1.2 \mathrm{~mm}$ wide towards the centre and widened towards the tips to $1-2 \mathrm{~mm}$ wide, dissected into secondary lobes to $0.7-1.5 \mathrm{~mm}$ long and to $0.7 \mathrm{~mm}$ wide (and to $0.4-0.5$ $\mathrm{mm}$ thick); yellow-brownish orange to brownish yellow-orange in peripheral portions, matt or somewhat shiny with rather scarce pseudocyphellae, while towards the centre number of pseudocyphellae becoming larger/higher to totally eroded upper surface, whitish-brownish yellow-orange; thalline lobes convex, along the lobe ends in peripheral zone seen that the lower portion of lobe white.

Apothecia 0.4-1.3(-1.5) mm diam., and 0.5-0.6 mm thick in section; at first immersed into thalline lobes, then uplifted on thalline warts in the centre, but not constricted at the basis; usually very compactly aggregated covering almost the whole central part, and areoles of central part hardly recognise, because they are completely covered by apothecia; lecanorine to zeorine, where thalline exciple yellowish-brownish orange and disc mainly plane, dark brownish brick-orange. In section true exciple to $40-70(-120) \mu \mathrm{m}$ thick in the uppermost lateral portion, to $30-70(-80) \mu \mathrm{m}$ thick in lower lateral portion and (20-)30-60(-150) $\mu \mathrm{m}$ thick in basal portion, intermediate type between "textura intricata" and "textura globosa", with very thin cell walls, where cell 
lumina to 2-3(-4) $\mu \mathrm{m}$ across; thalline exciple to $100-150(-170) \mu \mathrm{m}$ thick with cortical layer to $15 \mu \mathrm{m}$ thick, paraplectenchymatous (in K to $30 \mu \mathrm{m}$ thick of lax paraplectenchyma, cells to 5-7 $\mu \mathrm{m}$ across); algal cells to 10-11 $\mu \mathrm{m}$ diam.; hymenium 100-120 $\mu \mathrm{m}$ high; epihymenium to $25 \mu \mathrm{m}$ thick in K more or less becoming darker; paraphyses gradually becoming wider towards the tips to 4-6 $\mu \mathrm{m}$ diam. in water (and distinctly widened towards the tips to $4-5 \mu \mathrm{m}$ diam. in $\mathrm{K})$; subhymenium to $70-110(-300) \mu \mathrm{m}$ thick, with numerous oil droplets to 5-6 $\mu \mathrm{m}$ diam.; asci 8-spored, uniseriate; ascospores seem to be simple (see below), straight or somewhat curved, almost cylindrical (10.5-)11-16(-17) $\times$ $(4.5-) 5-6.5(-7) \mu \mathrm{m}$ in water and (10-)12-15(-16) × (4-)5-7 $\mu \mathrm{m}$ in K (measurements mainly with halo); ascospore wall in water to $0.5 \mu \mathrm{m}$ thick, and with halo well distinct to 1-1.2(-1.5) $\mu \mathrm{m}$ wide in $\mathrm{K}$ (while not seen in water); septum mainly not developed (not seen in water) or only juvenile stage of septum observed in $\mathrm{K}$, to $1.5-2(-2.5) \mu \mathrm{m}$ wide (septum developed only at spore wall and not developed in the centre).

Chemistry: Thallus K+ purple. Epihymenium and cortical layer of thalline exciple $\mathrm{K}+$ bright crimson purple washing in liquid; cortex of thalline section $\mathrm{K}+$ bluish, violet- or ink-purple.

Ecology: It grows on siliceous rock.

Distribution: So far known only from the type locality in Chile, South America.

Etymology: Species is named after similarities to the Canary Islands endemic Elenkiniana gomerana.

Taxonomic notes: This taxon is characterised by the following features: lobate peripheral zone, lobes mainly matt and slightly lighter at the tips, yellowish-brownish or yellow-brownish orange; areoles in the centre richly covered by pseudocyphellae and upper surface seem to be heavily eroded and whitish-yellowish brown in contrast to dark brick-orange discs of apothecia, which are very abundant, almost completely covered some parts in the centre; ascospores mainly simple (only very rarely juvenile septum seen); very soft tissue in the true exciple (well developed, but concave), as well as presence of halo in ascospores.

Harusavskia elenkinianoides is similar to the Canary Islands endemic Elenkiniana gomerana (J. Steiner) S. Y. Kondr., Kärnefelt, A. Thell, Elix, J. Kim, A. S. Kondr. et J.-S. Hur in having areolate in the centre and lobate in peripheral zone and the same colouration thallus, in having numerous pseudocyphellae in the centre and more or less immersed into the thallus apothecia, but differs in having shorter (2-3.5 mm vs. to $8 \mathrm{~mm}$ long after Steiner 1911), and much wider (0.8-1.2 $\mathrm{mm}$ wide towards the centre and to 1-2 $\mathrm{mm}$ wide towards the tips, vs. 0.3-0.7(-1) $\mathrm{mm}$ wide) thalline lobes, in having somewhat larger apothecia (0.4-1.3(-1.5) $\mathrm{mm}$ vs. 0.5-0.7(-1.2) $\mathrm{mm}$ diam.), in having lower cortical layer (to 15(-30) $\mu \mathrm{m}$ vs. 37-65 $\mu \mathrm{m}$ after Llimona and Werner 1975, and 16-28 

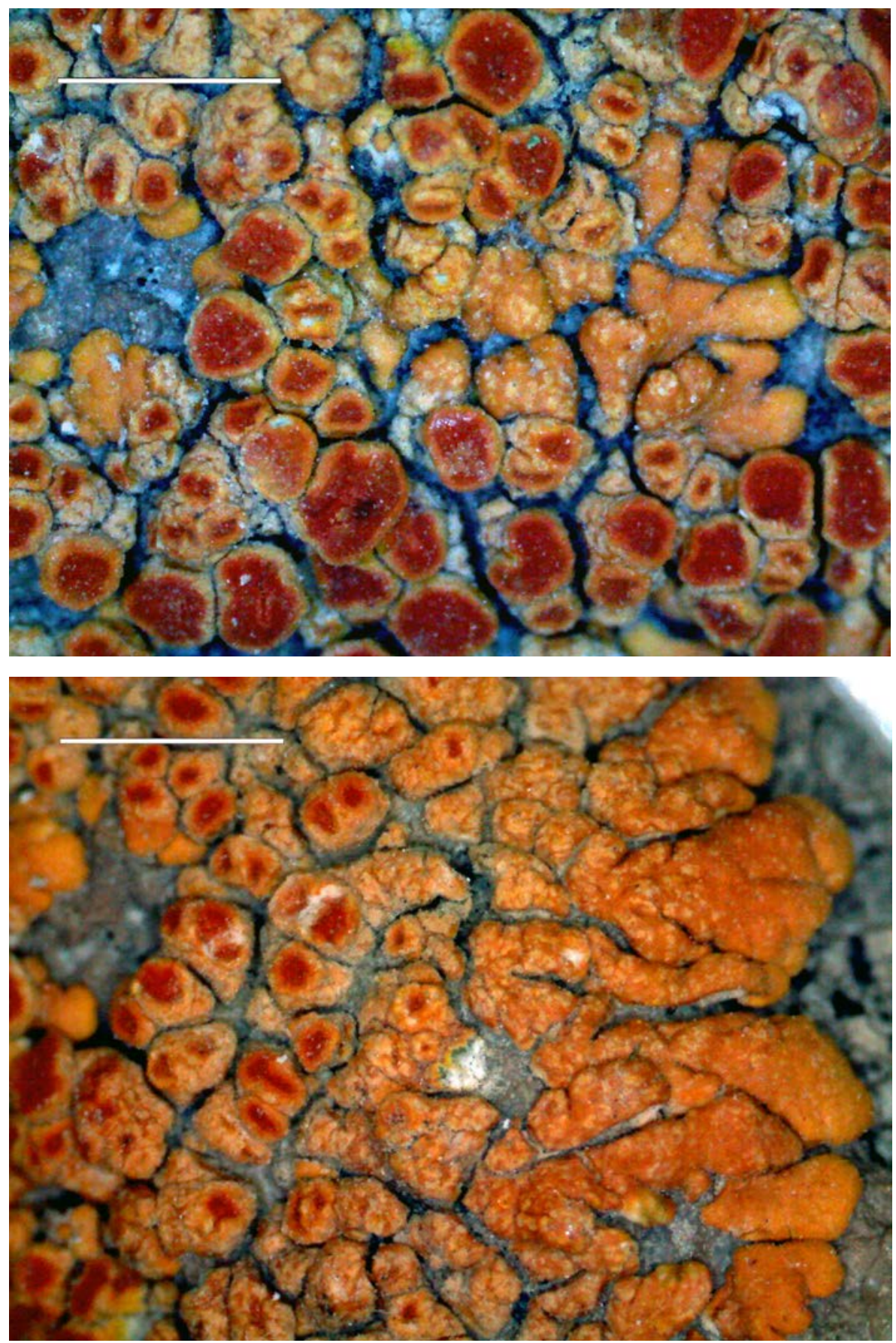

Fig. 9. Harusavskia elenkinianoides (holotype). Scale $2 \mathrm{~mm}$. (Photo of S. Kondratyuk) 
$\mu \mathrm{m}$ after Steiner 1911), in having much thicker true exciple especially in basal portion (30-60(-150) $\mu \mathrm{m}$ vs. $25 \mu \mathrm{m}$ thick), and in having "textura intricata" or "textura globosa" of true exciple (vs. of parallel hyphae), in having higher hymenium (100-120 $\mu \mathrm{m}$ vs. 60-90 $\mu \mathrm{m}$ high), in having larger ascospores ((10.5)11-16(-17) × (4.5-)5-6.5(-7) $\mu \mathrm{m}$ vs. 7.5-9.9-12.5 × 4-5.5-6 $\mu \mathrm{m}$ after Llimona and Werner 1975, and 7.5-11 × 5.5-6.5 $\mu \mathrm{m}$ after Steiner 1911), and in having narrower ascospore septum $(1.5-2 \mu \mathrm{m}$ vs. $2-4 \mu \mathrm{m}$ wide), as well as in having ascospores with halo.

Harusavskia elenkinianoides is similar to the epiphytic Chilean taxon $\mathrm{Ca}$ loplaca chilensis S. Y. Kondr., Kärnefelt, Frödén et Arup, but differs in having larger thallus (several $\mathrm{cm}$ vs. $8-15(-25) \mathrm{mm}$ diam.), being areolate in the centre, in having much wider thalline lobes (0.8-1.2 $\mathrm{mm}$ vs. $0.2-0.4 \mathrm{~mm}$ wide), in having pseudocyphellae, in having wider paraphysis tips $(4-6 \mu \mathrm{m}$ vs. to $3 \mu \mathrm{m}$ diam.), in the lack of rhizine-like structures on underside and prothallus, in having smaller and nonstipitate apothecia $(0.4-1.3 \mathrm{~mm}$ vs. $0.4-2.7 \mathrm{~mm}$ diam., stipe $0.3-1 \mathrm{~mm}$ long), in having much narrower ascospore septum $(1.5-2 \mu \mathrm{m}$ vs. $4-6(-7.5) \mu \mathrm{m}$ wide), as well as in saxicolous habit, and having ascospores with halo.

Unfortunately molecular data on Caloplaca chilensis are still not available, while data on 6 genes of Caloplaca chilensis were mentioned in literature (Gaya et al. 2012). However, in fact these data belong to another taxon of the genus Follmannia.

After having convex thalline lobes with white sides along the lobe ends in the peripheral zone, as well as after having indistinctly whitish in the centre thallus Harusavskia elenkinianoides is similar to Calogaya mogoltanica (S. Y. Kondr. et Kudratov) S. Y. Kondr., Kärnefelt, Elix, A. Thell, J. Kim, M.-H. Jeong, N.N. Yu, A. S. Kondratiuk et J.-S. Hur known from limestone outcrops of Central Asia (Tadjikistan and Iran). However, Harusavskia elenkinianoides differs in having brownish orange, epruinose (vs. dirty greenish yellow pruinose) thallus, smooth in the centre (vs. papillate and verruculose in the centre), in having thinner thalline lobes $(0.4-0.5 \mathrm{~mm}$ vs. to $1-2(-3) \mathrm{mm}$ thick), which well deliminated by wide cracks between each others (vs. indistinct in the centre of thallus and only seen as upper portion of convex surface of cortical layer), in having pseudocyphellae (vs. pruinose but without pseudocyphellae), in having smaller (mainly to $1 \mathrm{~mm}$ vs. $0.8-1.8 \mathrm{~mm}$ diam. not constricted at the basis zeorine apothecia (lecanorine, with thick thalline margin, attenuated at the basis), in having "textura intricata" or "textura globosa" type of true exciple (vs. well-developed paraplectenchymatous with well-developed matrix) in having shorter ascospores $(12-15 \times 5-7 \mu \mathrm{m}$ vs. 15-18 × 6-7 $\mu \mathrm{m})($ Kondratyuk and Kudratov 2003). 
In contrast to Rusavskia elegans (Link) S. Y. Kondr. et Kärnefelt (to which this material was originally included), it has distinctly areolate central portion of thallus, and lobes do not have well-developed lower cortex, as well as ascospores have halo, while septum is not well distinct.

Huriella S. Y. Kondr. et D. Upreti, gen. nov.

MycoBank nr.: MB 819645.

Similar to the genus Squamulea of the subfamily Teloschistoideae, but differs in having areolate (not squamulose!) thallus, smaller zeorine apothecia, in having narrower ascospores, as well as in positioning in separate robust monophyletic branch in the Amundsenia-Squamulea clade.

Type species: Huriella loekoesiana S. Y. Kondr. et D. Upreti.

Thallus crustose, small, but often forming larger aggregations, areolate (not squamulose!), dull yellow-brownish or yellowish green. Cortical layer paraplectenchymatous. Hypothallus not observed.

Apothecia small, seem to be biatorine, but zeorine in section, 1(-3-4) per areole, disc dull yellow to bright yellow (especially at initial stages) to dark brownish yellow; own margin concolourous with disc; true exciple paraplectenchymatous; asci 8-spored; ascospores polarilocular, small, widely ellipsoid with rounded ends. Conidiomata and conidia not seen.

Chemistry and ecology see below in species description.

Distribution and species diversity: So far monotypic genus, while possibly includes complex of species. H. loekoesiana is known from numerous localities in South Korea, Eastern Asia.

Etymology: It is named after Prof. Jae-Seoun Hur (Suncheon, Republic of Korea), who has kindly supported our study of the Teloschistaceae.

Taxonomic notes and phylogenetic affiliations: After combined phylogenetic analysis, as well as after separate ITS and mtSSU analyses the genus Huriella is always positioned in a sister position to the genera Squamulea and Amundsenia (or between the Amundsenia-Squamulea and the Xanthocarpia clades, if limited number of genera are included into the phylogenetic analysis) as separate robust monophyletic branch, while the level of support of the whole Amundsenia-Squamulea clade in much lower.

After molecular data hitherto available the genus Huriella includes only the type species, while we expect in future recognising a complex of taxa. One more species very similar to H. loekoesiana is in preparation for official publication. 
Huriella loekoesiana S. Y. Kondr. et D. Upreti, spec. nova (Fig. 10)

MycoBank nr.: MB 819646.

Similar to Squamulea micromera, but differs in having areolate (not squamulose!) thallus, in having larger thalline areoles, in having larger zeorine apothecia and in having narrower ascospores.

Type: Republic of Korea. Gangwon-do: Jeongseon-gun, Buk-myeon, Mt Baennon, on rock, growing together with Laundonia flavovirescens agg., Rinodina sp. Lat.: $37^{\circ} 26^{\prime} 34.9^{\prime \prime} \mathrm{N}$; Long.: $128^{\circ} 45^{\prime}$ 21.3" E; Alt.: ca $748 \mathrm{~m}$ a.s.l. Coll.: Wang, X. Y., Jeon, H. S., Lü, L. and Ryu, J. A. (100803), 28.05.2010 (KoLRI 012491 - holotype).

Thallus 2-4(-10) $\mathrm{mm}$ across, but forming larger aggregations to $5-10 \mathrm{~cm}$ across, crustose, areolate (not squamulose!), dull yellow-brownish, yellowgreenish; areoles $(0.2-) 0.3-0.8(-1.0) \mathrm{mm}$ across, from regularly rounded to irregular, somewhat distant and scattered, with more or less even surface, becoming thinner towards the edges (not uplifted towards the edges!). Thallus in section to (60-)70-100(-120) $\mu \mathrm{m}$ thick; cortical layer to 10-15 $\mu \mathrm{m}$ thick, outermost portion somewhat brownish-yellowish in places, paraplectenchymatous, cell lumina to 5-7 $\mu \mathrm{m}$ diam./across; algal layer to $40-70 \mu \mathrm{m}$ thick; medulla not developed or $c a 10-30 \mu \mathrm{m}$ thick below the algal layer in places. Hypothallus not observed.

Apothecia 0.2-0.4(-0.5) $\mathrm{mm}$ diam., to $0.2 \mathrm{~mm}$ thick in the section; 1(-34) per areole, immersed in thallus at first then sessile, seem to be biatorine, but zeorine in section; disc dull yellow to bright yellow, especially at initial stages (lighter than thallus) to dark brownish yellow at overmature, own margin bright or light yellow, concolourous with disc of young apothecia; in section zeorine, true exciple to $40-50 \mu \mathrm{m}$ wide in the uppermost lateral portion, consisting of rounded cells to 5-6(-7) $\mu \mathrm{m}$ diam./across, to 10-15 $\mu \mathrm{m}$ thick in lower lateral portion and to $25-30 \mu \mathrm{m}$ thick in basal portion, paraplectenchymatous, cell lumina 3-5 $\mu \mathrm{m}$ diam./across; thalline exciple to $40-50$ $\mu \mathrm{m}$ thick, with well-developed cortical layer to 10-15 $\mu \mathrm{m}$ thick, paraplectenchymatous; cell rounded 5-7 $\mu \mathrm{m}$ diam./across; algal layer below true exciple entire or in clusters, algal cells to 13-20(-23) $\mu \mathrm{m}$ diam.; hymenium to 50-60 $\mu \mathrm{m}$ high; paraphyses distinctly swollen towards the tips to $5(-6) \mu \mathrm{m}$ diam.; subhymenium 20-30 $\mu \mathrm{m}$ thick, hyaline, without oil; asci 8-spored; ascospores widely ellipsoid with rounded ends, $(8.5-) 9-11(-12) \times(4.5) 5-6 \mu \mathrm{m}$ in water and becoming especially wider to (8-)10-12(-13) $\times 6-7.5(-8) \mu \mathrm{m}$ in $\mathrm{K}$; septum $(3.5-) 4-5(-6) \mu \mathrm{m}$ wide in water and $4-6(-7) \mu \mathrm{m}$ wide in $\mathrm{K}$. Conidiomata and conidia not seen. 

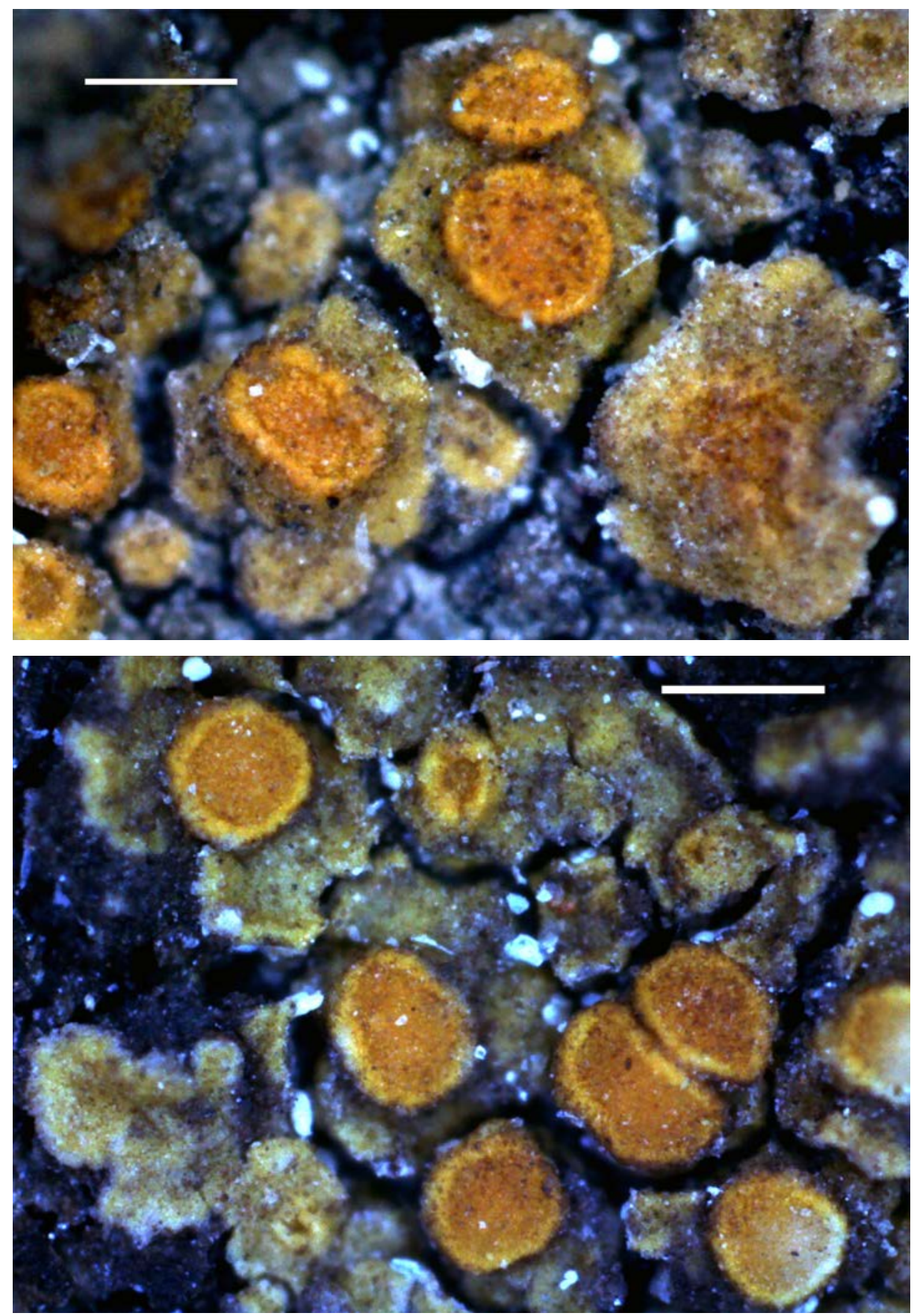

Fig. 10. Huriella loekoesiana (holotype), general habit. Scale $0.5 \mathrm{~mm}$. (Photo of S. Kondratyuk) 
Chemistry: Cortical layer of thallus, epihymenium and outer portion of true exciple and thalline exciple $\mathrm{K}+$ purple; outer brownish portions of thalline cortical layer $\mathrm{K}+$ dark brown purple; substances not studied.

Ecology: It grows on siliceous rocks growing often together with Laundonia flavovirescens agg., Rinodina sp.

Distribution: Known from scattered localities throughout the Republic of Korea, Eastern Asia.

Etymology: Species is named after our good friend and colleague, wellknown Hungarian lichenologist László Lőkös (BP, Budapest) in recognition of his contribution to our recent knowledge on Korean lichen flora.

Taxonomic notes: Huriella loekoesiana is characterised by very small light yellow discs of apothecia, slightly lighter of (dull brownish yellow) colour of thallus, by areolate thallus with more or less rounded scattered areoles and small and especially narrow ascospores.

Huriella loekoesiana is similar to Squamulea micromera (Hue) S. Y. Kondr., L. Lőkös et J.-S. Hur, but differs in having areolate thallus (vs. squamulose), in having larger thalline areoles $((0.2-) 0.3-0.8(-1.0) \mathrm{mm}$ vs. $0.2-0.3 \mathrm{~mm}$ diam./ across), in having larger zeorine apothecia $(0.2-0.4(-0.5) \mathrm{mm}$ vs. $0.2-0.3(-0.4)$ $\mathrm{mm}$ diam., biatorine), in having thinner true exciple in basal portion (25-30 $\mu \mathrm{m}$ vs. $40-60 \mu \mathrm{m}$ thick), in having thinner subhymenium $(20-30 \mu \mathrm{m}$ vs. $50-60$ $\mu \mathrm{m}$ thick), and in having narrower ascospores $((8.5-) 9-11(-12) \times(4.5-) 5-6 \mu \mathrm{m}$ vs. 9-12 × 6-7(-7.5) $\mu \mathrm{m})$.

Huriella loekoesiana is similar to Squamulea subsoluta (Nyl.) Arup, Søchting et Frödén, the type species of genus Squamulea Arup, Søchting et Frödén, but differs in having smaller thalline areoles (not squamules, $0.3-0.8(-1.0) \mathrm{mm}$ vs. $0.1-2.5 \mathrm{~mm}$ wide); in having smaller apothecia $(0.2-0.4(-0.5) \mathrm{mm}$ vs. $0.1-0.6$ $(-1.0) \mathrm{mm}$ diam.), in having narrower ascospores $((8.5-) 9-11(-12) \times(4.5-) 5-6$ $\mu \mathrm{m}$ vs. 9.5-12.5(-14) $\times 5.5-7 \mu \mathrm{m})$, and in having wider ascospore septum $(4-5$ $\mu \mathrm{m}$ vs. 3-4 $\mu \mathrm{m}$ wide).

It should be emphasised that taxonomic status of Squamulea micromera is waiting for confirmation by molecular data from freshly collected specimens. In general, the type specimen of $S$. micromera may be considered within the variation of $S$. subsoluta (Nyl.) Arup, Søchting et Frödén (sensu Wetmore 2003). However, we prefer to keep S. micromera as separate taxon until molecular characters of this material will not be checked especially.

There is one more taxon, very similar to Huriella loekoesiana, but differing in having smaller ascospores and other anatomical characters, which is probably also the member of the genus Huriella is in preparation.

Other specimens studied selected: Republic of Korea. Chungcheongbuk-do, Danyang-gun, Danseong-myeon, Daejam-ri, 584 Road, near Sunam Valley, on rock growing together with Phaeophyscia and Endocarpon. Lat.: $36^{\circ} 54^{\prime} 20.8^{\prime \prime}$ N; Long.: $128^{\circ} 18^{\prime} 42.9^{\prime \prime}$ E; Alt.: 
ca 207 m a.s.l. Coll.: Lee, B. G. (152763), 05.09 .2015 (KoLRI 037750 sub Huriella). - Gyeongsangbuk-do, Ulleung-do Island, Ulleung-gun, Seo-myeon, Namyang-ri, Turtle Rock (Mt 18-1), seashore rocks, on basalt. Lat.: $37^{\circ} 27^{\prime} 36.5^{\prime \prime} \mathrm{N}$; Long.: $130^{\circ} 51^{\prime}$ 27.9" E; Alt.: $2 \mathrm{~m}$ a.s.l. Coll.: Kondratyuk, S. Y. and Lőkös, L. (161904), 10.07.2016. (KoLRI 40141 sub Candelariella). - Gyeongsangbuk-do, Ulleung-do Island, Ulleung-gun, Ulleung-eup, Dodong-ri, Seaside Trail near Dodong Port, on steep siliceous rocks, growing together with Squamulea squamosa. Lat.: 37 28' 59.9” N; Long.: 130 54' 40.7" E; Alt.: 20 m a.s.l. Coll.: Kondratyuk, S. Y. and Lőkös, L. (161998), 11.07.2016. (KoLRI 40236 sub Squamulea squamosa); the same locality, (162000), (KoLRI 40238 sub Squamulea squamosa). - Jeju-do, Seogwipo-si, Eongsaneup, Goseong-ri, Seopjicoji, on rock growing together with Buellia stellulata, and Agonimia cavernicola. Lat.: $33^{\circ} 19^{\prime}$ 21.0" N; Long.: 126 50' 49.03" E; Alt.: ca 69 m a.s.l. Coll.: Gagarina, L. (140363), 19.06.2014 (KoLRI 022729 sub Buellia stellulata); the same locality and collector, (140355), (KoLRI 022723). - Jeju-do, Seogwipo-si, Sangjeong-dong, Yeongtto waterfall, on rock, growing together with Acarospora ulleungdoensis [Note: first time recorded from Cheju-do Island]. Lat.: $33^{\circ} 16^{\prime}$ 01.7" N; Long.: 126 29' 49.00" E; Alt.: ca $210 \mathrm{~m}$ a.s.l. Coll.: Joshi, Y. and So, J.-U. (140595), 19.06.2014 (KoLRI 022989). - Jeju-do, Jeju-si, Gujwa-eup, Gimnyeong-ri, Gimnyeong Beach, seaside, on rock, growing together with Leptogium sp., Endocarpon sp., Pyrenopsis sp. Lat.: 33 33' 53.91" N; Long.: $126^{\circ} 45^{\prime}$ 47.66" E; Alt.: ca 10 $\mathrm{m}$ a.s.1. Coll.: Hur, J.-S., Wang, X. Y., Ryu, J. A. and Hur, J. Y. (090020), 19.04.2009 (KoLRI 009784). - Jeollanam-do, Yeosu-si, Nam-myeon, Dumo-ri, Jickpo coast, Geumo-do, on rock. Lat.: $34^{\circ} 30^{\prime} 46.08^{\prime \prime} \mathrm{N}$; Long.: $127^{\circ} 44^{\prime} 16.04^{\prime \prime}$ E; Alt.: ca $30 \mathrm{~m}$ a.s.l. Coll.: Jayalal, U., Park, J. S. and Ryu, J. A. (120433), 26.04.2012 (KoLRI 015423 sub Squamulea subsoluta). - Jeollanam-do, Yeosu-si, Nam-myeon, Simjang-ri, Geumo-do, on rock, growing together with Thelidium japonicum. Lat.: $34^{\circ} 28^{\prime} 59.20^{\prime \prime} \mathrm{N}$; Long.: $127^{\circ} 48^{\prime} 15.48^{\prime \prime}$ E; Alt.: ca 4 m a.s.l. Coll.: Halda, J. P. (160440), 10.06.2016 (KoLRI 038585 sub Thelidium japonicum (det. by Halda, J. P.)). - Jeollanam-do, Sinan-gun, Haui-myeon, Unggok-ri, Haui-do, seaside, on rock growing together with Orientophila subscopularis. Lat.: $34^{\circ} 36^{\prime} 07.07^{\prime \prime}$ N; Long.: $126^{\circ} 00^{\prime} 52.02^{\prime \prime}$ E; Alt.: ca 20 m a.s.l. Coll.: Oh, S.-O., Park, J. S. and Woo, J.-J. (130672), 28.06.2013 (KoLRI 019017 sub Orientophila subscopularis).

Ikaeria S. Y. Kondr., D. Upreti et J.-S. Hur, gen. nov.

MycoBank nr.: MB 819647.

Similar to Mikhtomia of the subfamily Caloplacoideae, but differs in having zeorine or lecanorine apothecia, and in forming separate robust monophyletic branch in the Teloschistoideae. Hur.

Type species: Ikaeria aurantiellina (Harm.) S. Y. Kondr., D. Upreti et J.-S.

Thallus crustose, continuous, yellowish or greyish or whitish yellow. Hypothallus sometimes present.

Apothecia zeorine or lecanorine, disc orange to brownish orange, true exciple of "textura intricata" or somewhat scleroplectenchymatous, asci 8-spored, ascospores polaribilocular. 
Chemistry: Not studied.

Ecology: Growing on bark of twigs of shrubs or trees.

Distribution and species diversity: So far this genus is monophyletic and known only from the Canary Islands.

Etymology: The genus is named after the well-known Swedish lichenologist Ingvar Kärnefelt (Lund, Sweden) in recognition of his contribution to lichenology, and who has kindly provided for us an opportunity to participate in field trips to Australia and to the Canary Islands and provided his earlier collections in our disposal.

Taxonomic notes and phylogenetic affiliations: After combined phylogenetic analysis the genus Ikaeria is positioned in the subfamily Teloschistoideae. From molecular data hitherto available the genus is monotypic including only type species I. aurantiellina, known from the Canary Islands and southwestern Europe.

Ikaeria aurantiellina is similar to Mikhtomia of the subfamily Caloplacoideae (or to Leutrouitia of the Leutrouitiaceae), but differs in having zeorine or lecanorine apothecia, bipolar ascospores and in forming separate robust monophyletic branch in the Teloschistoideae.

Ikaeria aurantiellina is similar to taxa of the Mikhtomia s.l. subphylum, especially of the genera Laundonia, Opeltia, etc., but differs in positioning in somewhat out position to both Caloplacoideae and Teloschistoideae after ITS, nrLSU and mtSSU analysis, as well as after combined phylogenetic analysis.

This genus often forms common branch with the genus Yoshimuria, but level of support of this branch is rather low to make conclusion that they are congeneric. In contrast, both genera, Ikaeria and Yoshimuria, have the highest level of support if they are presented by the same number of specimens (not shown in Figs 1-4).

Data on unique position of the genus Ikaeria were already obtained several years ago. However, these data were obtained from different specimens. Several attempts to get three gene sequences from the same specimen were attempted, but they were unsuccessful. So this genus, the same as genus Fominiella (see above) is in urgent need of confirmation by molecular data obtained from the same specimen.

After having broom-like paraphyses often becoming brownish towards the tips the genus Ikaeria is similar to the Australian 'Caloplaca' marchantiorum S. Y. Kondr. et Kärnefelt (Kondratyuk et al. 2009) (supposed member of the Teloschistoideae or Brownlielloideae). Molecular data on 'Caloplaca' marchantiorum are still not available, while several attempts to extract DNA were attempted.

Van den Boom and Etayo (2006) argue that the name Caloplaca aegatica Giralt, Nimis et Poelt, known from western Europe, might be a later synonym of Ikaeria aurantiellina. 
Klauderuiella S. Y. Kondr. et J.-S. Hur, gen. nov.

MycoBank nr.: MB 819648.

Similar to Variospora of the subfamily Caloplacoideae, but differs in having lobate portions in peripheral portion of thallus, in having lecanorine apothecia, and in forming separate robust monophyletic branch.

Type species: Klauderuiella thallincola (Wedd.) S. Y. Kondr. et J.-S. Hur.

Thallus distinctly lobate (at least in peripheral portions, while areolate in the centre); often large size, yellow to orange, sometimes central and peripheral zone differently coloured (various shades of orange colour), matt, epruinose or rarely pruinose; lobes plane or convex; cortical layer "pseudo" paraplectenchymatous (sensu Clauzade and Roux 1985).

Apothecia lecanorine to zeorine; true exciple scleroplectenchymatous with well-developed matrix in basal portion and to paraplectenchymatous in lateral portions; subhymenium with oil droplets or greyish owing to numerous crystals; ascospores often widened in equatorial portion to rhombic or citriform.

Ecology: Growing especially on calcium containing rocks.

Distribution: Members of this genus are known as widely distributed in the Northern Hemisphere.

Etymology: It is named after the well-known French lichenologist Claude Roux (Klaŭdo Roux in Esperanto) (1945-) in recognition of his enormous contribution to lichenology. He also excellently illustrated the Klauderuiella thallincola and Klauderuiella aurantia groups in the well-known work "Likenoj de Okcidenta Eŭropo. Illustrata determinlibro." (1985), as well as he is a great patriot of the Esperanto language.

Taxonomic notes and phylogenetic affiliations: In current phylogenetic tree the genus Klauderuiella, i.e.: the Variospora thallincola group has the highest level of support after combined three gene phylogeny in contrast to very low support of the Variospora-Bryoplaca subclade, where it is positioned (see Fig. 2). The latter subclade (i.e.: the Variospora-Bryoplaca subclade) is probably still heterogeneous.

After molecular data hitherto available the genus Klauderuiella includes three species, i.e.: K. thallincola, K. aurantia and K. flavescens.

From morphological point of view the genus Klauderuiella has very good (distinct) character - lobate in peripheral portion of the thallus in contrast to crustose members of the genus Variospora s. str. (i.e.: V. velana (A. Massal.) Arup, Søchting et Frödén, V. latzelii (Servit) S. Y. Kondr., V. macrocarpa (Anzi) Arup, Søchting et Frödén, V. dolomiticola (Hue) Arup, Søchting et Frödén and V. kudratovii (S. Y. Kondr., B. Zarei-Darki et Hur) S. Y. Kondr., Kärnefelt, A. Thell, Elix, J. Kim, A. S. Kondr. et Hur). 
The Klauderuiella is somewhat analogous to genera Flavocitrina and Calogaya in the Xanthorioideae and Filsoniana in the Teloschistoideae. However, the genus Klauderuiella differs in having different type of paraplectenchymatous tissue in cortical layer, as well as in having typical bipolar ascospores (without thickening at poles).

Status of Variospora latzelii and V. australis hitherto included in this genus Variospora only after ITS phylogeny should be confirmed by data on nrLSU and $\mathrm{mtSSU}$.

Possibly one more monophyletic group will be segregated from the Variospora s.l. branch of the Caloplacoideae in future.

Laundonia S. Y. Kondr., L. Lőkös et J.-S. Hur, gen. nov.

MycoBank nr.: MB 819649.

Similar to the genus Mikhtomia of the subfamily Caloplacoideae, but forming separate robust monophyletic branch.

Type species: Laundonia flavovirescens (Wulfen) S. Y. Kondr., L. Lőkös et J.-S. Hur.

Thallus crustose, continuous or areolate, margin thinning at edge, without elongated lobes; yellowish grey, yellowish orange, tan orange to greenish yellow or greenish orange, pruinose, without vegetative propagules or sorediate; prothallus absent or present, black.

Apothecia of medium size, lecanorine or biatorine, disc dark orange, reddish orange or brownish orange; true exciple consisting of radiating hyphae to "textura intricata" in basal portion; asci 8-spored; ascospores polaripolucar, hyaline.

Unfortunately data on conidia of type species and L. persimilis (see Wetmore 2007) not provided, while description of conidiomata present in descriptions.

Chemistry: Parietin, fallacinal, emodin, and teloschistin. Chemistry of $L$. persimilis was not especially investigated, however, $\mathrm{C}+$ reaction may illustrate the presence of gyrophoric or lecanoric acids.

Ecology: It grows on wood or bark.

Etymology: It is named after the well-known British lichenologist Jack Rodney Laundon (1934-) who has made important contribution to taxonomy of this species complex.

Distribution: Type species, i.e. Laundonia flavovirescens is widely distributed in the Northern Hemisphere (see notes below), while L. persimilis is known only from western North America.

Taxonomic notes and phylogenetic affiliations: After combined phylogenetic analysis the genus Laundonia is positioned in out position to the other 
genera of the Mikhtomia clade of the Caloplacoideae (Fig. 2), and it includes two species, i.e.: L. flavovirescens and L. persimilis.

In premolecular era it was thought that Laundonia flavovirescens is a rather common taxon distributed world wide (see Wetmore 2007). However, when we have started extraction DNA and further sequencing appeared material morphologically similar to Laundonia flavovirescens to belong to many other genera like Yoshimuria S. Y. Kondr., Kärnefelt, Elix, A. Thell et Hur, Mikhtomia S. Y. Kondr., Kärnefelt, Elix, A. Thell et J.-S. Hur (subfamily Caloplacoideae), Orientophila Arup, Søchting et Frödén (subfamily Xanthorioideae) (Kondratyuk et al. 2016d), while Laundonia flavovirescens is rather rare itself.

Species of the genus Laundonia are very similar to members of the genus Mikhtomia in its current sense, especially in the Eastern Asian region. Many species of the latter genus (i.e. Mikhtomia), as well as the genus Oxneriopsis were segregated from the so-called Caloplaca flavovirescens group.

However, genus Laundonia differs in having zeorine or lecanorine apothecia, in the lack of vegetative propagules, and in positioning in the outermost position to the genus Mikhtomia of the Mikhtomia s.l. clade.

It can be similar to some species of the genus Tomnashia of the Xanthorioideae (see below), but differs in having lecanorine mainly orange to dark orange apothecia (without reddish tinge), as well as in preference to non-calcareous rocks, while occasionally growing on calcareous rocks, too.

From morphological point of view the rare, Eastern Asian, recently described taxon Caloplaca kedrovopadensis S. Y. Kondr. et J.-S. Hur (Kondratyuk et al. 2014b, 2016a) can be also candidate in being member of the genus Laundonia. However, molecular data are still missing for this taxon.

Earlier species of this genus were included mainly after ITS phylogeny to the genus Gyalolechia s.l. (Arup et al. 2013a), which was characterised by dominance of fragilin and presence of smaller amounts of parietin and emodin (often/sometimes with additional depsidones). However, as it was later shown the Gyalolechia s. str. branch including G. aurea and G. canariensis has the highest level of support, but this branch is in out position to the Mikhtomia s.l. clade (Kondratyuk et al. 2014c, and Fig. 2 in this paper). The genus Laundonia forms separate robust monophyletic branch within the Mikhtomia s.l. clade.

Lazarenkoiopsis S. Y. Kondr., L. Lőkös et J.-S. Hur, gen. nov. MycoBank nr.: MB 819650.

Similar to genus Solitaria of the subfamily Xanthorioideae, but differs in having distinctly cracked-areolated, much thicker thallus, numerous oil droplets in the hymenium, "textura intricata" tissue in the true exciple, not swollen towards the tips of paraphyses, as well as in having higher concentrations of fragilin and detectable 
quantity of emodin, 7-chloro-emodin, erythroglaucin, 7-chloroparietinic acid, physcoin bysanthrone, physcoin 9-anthrone and physcoin 10-anthrone, as well as in positioning in the Caloplacoideae.

Type species: Lazarenkoiopsis ussuriensis (Oxner, S. Y. Kondr. et Elix) S. Y. Kondr., L. Lőkös et J.-S. Hur.

Thallus rather thick in the centre and very thin at the periphery, smooth to distinctly cracked by rather broad cracks, upper surface whitish, dull greyish white to grey, greenish grey-brown or dull greenish yellow with wellcontrasting bright yellow, dull yellow or dull brownish yellow soralia. Soralia initially rounded or irregular, usually at the margins of areoles, then becoming confluent and spectacular elongated, fissure-like. Sorediose mass convex, yellow to greenish yellow or dull brownish yellow.

Apothecia zeorine or lecanorine, disc brown to dark brown, own margin dull yellow to almost colourless; cortical layer of thalline exciple paraplectenchymatous; true exciple of "textura intricata" or poorly developed scleroplectenchyma with cell lumina of 1-1.5 $\mu \mathrm{m}$ diam.; asci 8-spored; ascospores broadly ellipsoid to almost spherical or elongated and fusiform.

Chemistry: It contains fragilin (major), parietin (major/minor), emodin and physcoin bysanthrone (minor), and 7-chloroemodin, erythroglaucin, 7-chloroparietinic acid, physcoin 9-anthrone, and physcoin 10-anthrone (trace).

Etymology: It is named after the well-known Ukrainian bryologist Andrij Sozontovych Lazarenko (1901-1979) for his contribution to the bryoflora of the Eastern Asian region.

Ecology: It grows on various deciduous trees, especially on Acer pseudosieboldianum, growing together with Oxneriopsis oxneri and Caloplaca cerina.

Taxonomic notes and phylogenetic affiliations: Lazarenkoiopsis ussuriensis is similar to Solitaria chrysophthalma (Degel.) Arup, Søchting et Frödén, but differs in having a much thicker, distinctly cracked-areolated thallus, numerous oil droplets in the subhymenium, more or less "textura intricata" tissue in the true exciple (scleroplectenchymatous in S. chrysophthalma), paraphyses not swollen towards the tips (4-6.5 $\mu \mathrm{m}$ wide in S. chrysophthalma), a thinner exciple, as well as higher concentrations of fragilin and detectable quantity of emodin, 7-chloroemodin, erythroglaucin, 7-chloroparietinic acid, physcoin bysanthrone, physcoin 9-anthrone, and physcoin 10-anthrone, as well as in positioning in the Teloschistoideae (Fig. 1). The dimensions of the ascospores and ascospore septa are very similar for these two species.

Lazarenkoiopsis ussuriensis regularly grows together with Oxneriopsis oxneri (S. Y. Kondr. et Søchting) S. Y. Kondr., D. Upreti et J.-S. Hur, so it often appears that the same thallus produces both isidia and soredia. The thalli of both species (especially after long storage in herbaria) are the same colour. 
However, when growing side by side, O. oxneri differs by characteristic ascending thalline fragments exposing the white medulla, while upper surface of Lazarenkoiopsis ussuriensis is always entire and medulla not apparent (except for soralia). Caloplaca cerina (Ehrh. ex Hedw.) Th. Fr. is also sometimes associated with Lazarenkoiopsis ussuriensis, but differs by its bright yellowish discs with a greyish thalline margin (in contrast to the darker brown discs in L. ussuriensis), as well as in lacking of soralia.

Suggestion that "Caloplaca oxneri would appear to be closely related to C. ussuriensis, but differs in having phyllidia and schistidia rather than welldeveloped soralia and convex sorediose mass" (Kondratyuk et al. 1996) is not supported by current molecular data. These taxa are members of the different robust monophyletic branches, i.e. the Oxneriopsis and Lazarenkoiopsis of the subfamilies Caloplacoideae and the Teloschistoideae, respectively.

Nevilleiella S. Y. Kondr., et J.-S. Hur, gen. nov.

MycoBank nr.: MB 819651.

Similar to genus Filsoniana of the subfamily Teloschistoideae, but differs in having crustose thallus and biatorine apothecia, as well as forming separate robust monophyletic branch.

Type species: Nevilleiella marchantii (S. Y. Kondr. et Kärnefelt) S. Y. Kondr. et J.-S. Hur.

Thallus crustose, developing almost spherical pustule-like formations or comprised of discrete, rather scattered distant areoles (which do not form entire crust), brownish yellow to brownish orange, sometimes with whitish pruina; areoles very variable, often convex, warty to almost spherical, sometimes with schizidia-like formations, cortical layer palisade paraplectenchymatous. Apothecia biatorine, sometimes becoming zeorine; disc and own margin rusty brownish orange or brownish orange, concolourous with thallus; true exciple paraplectenchymatous with distinct matrix in basal portion; subhymenium with oil droplets; ascospores polarilocular with almost invisible septum mounted in water (better seen in K). Conidia narrowly bacilliform, 3-4 × 0.8-1 $\mu \mathrm{m}$.

Chemistry: Parietin (major), fallacinal (submajor/minor), parietinic acid, teloschistin (minor/trace) present.

Ecology: It forms crust on clayey soil in saline areas, open localities or in mallee areas or on siliceous rocks along the coast and rough pasture, heathland and dry sclerophyll forest of Australian continent.

Etymology: This genus is named after Dr Neville Marchant, who kindly assisted us during our field work in Western Australia. 
Distribution and species diversity: The genus includes two species rather widely distributed in Australia.

Taxonomic notes and phylogenetic affiliations: After combined phylogenetic analysis the genus Nevilleiella is positioned within the Filsoniana clade of the Teloschistoideae (Fig. 1).

The genus Nevilleiella is similar to genus Filsoniana S. Y. Kondr., Kärnefelt, Elix, A. Thell et J.-S. Hur of the subfamily Teloschistoideae, but differs in having crustose thallus and biatorine apothecia, as well as forming separate robust monophyletic branch.

The type species Nevilleiella marchantii was mentioned as the closest to the member of the genus Filsoniana S. Y. Kondr., Kärnefelt, Elix, A. Thell et J.S. Hur, i.e. to F. scarlatina in the original publication (Kondratyuk et al. 2007). It was also compared with another Australian member of the same genus Filsoniana i.e.: F. rexfilsonii (S. Y. Kondr. et Kärnefelt) S. Y. Kondr., Kärnefelt, Elix, A. Thell et J.-S. Hur, but species of the genus Nevilleiella differs in the lack of oil droplets and oil cells in the paraphyses, and in having a very thin cortical layer, as well as much smaller, uniformly sized, ascospores in an ascus.

The taxonomic status of the second member of this genus, i.e. Nevilleiella lateritia is considered as rather questionable (Kantvilas 2016). Furthermore Nevilleiella lateritia considered as possible conspecific taxon with the Filsoniana scarlatina and F. rexfilsonii. However, molecular data confirm that these species have very good support as different species and that these taxa are members of two separate robust monophyletic branches (see also Kondratyuk et al. 2013b).

Opeltia S. Y. Kondr. et L. Lőkös, gen. nov.

MycoBank nr.: MB 819652.

Similar to the genus Blastenia, but differs in having zeorine and rusty brown apothecia, in having paraplectenchymatous true exciple, in having hymenium and especially subhymenium inspersed with oil, and in forming separate robust monophyletic branch in the Mikhtomia s.l. clade.

Type species: Opeltia neobaltistanica (S. Y. Kondr. et J.-S. Hur) S. Y. Kondr. et L. Lőkös.

Thallus crustose, areolate to subsquamulose, margin abrupt at edge, without elongated lobes; whitish to dirty white, weakly yellowish whitish in places or yellowish orange, without asexual propagules or sorediate; prothallus absent. Apothecia biatorine, zeorine to biatorine or lecanorine; disc dark reddish orange to rusty brown; true exciple paraplectenchymatous in basal portion to mesodermatous paraplectenchymatous with well-developed 
matrix; hymenium and especially subhymenium inspersed with oil; asci 8 -spored, ascospores polarilocular, often very varying in shape.

Chemistry: Parietin and emodin are recorded, while chemistry of all species of this genus is not studied in the same extent.

Ecology: It grows on bark of Juniperus, growing together with species of the genera Candelariella, Caloplaca, Lecidella, Rinodina, Phaeophyscia, and Physconia.

Etymology: The genus is named after the well-known German lichenologist Josef Poelt, in recognition of his enormous contribution to lichenology.

Distribution and species diversity: Two taxa, including the type species O. neobaltistanica, and O. juniperina, are known from Eurasia, while one species (O. arizonica) is known from southern North America.

Taxonomic notes and phylogenetic affiliations: After combined analysis the genus Opeltia is a member of the Mikhtomia s.l. clade of the Caloplacoideae, but forming separate robust monophyletic branch (Fig. 2). After molecular data hitherto available the genus Opeltia includes three species, i.e.: $O$. arizonica, O. juniperina and O. neobaltistanica.

After having yellow-orange areolate thallus it is similar to species of genus Laundonia (i.e. L. flavovirescens), while mainly growing on bark (vs. on rock), and with the exception of $O$. arizonica apothecia do not have visible thalline margin.

As it was mentioned earlier species of this genus were included mainly after ITS phylogeny to the genus Gyalolechia s.l. (Arup et al. 2013a), which was characterised by dominance of fragilin and presence of smaller amounts of parietin and emodin (often/sometimes with additional depsidones). However, as it was later shown the Gyalolechia s. str. branch including G. aurea and G. canariensis has the highest level of support, but this branch is in out position to the Mikhtomia s.l. clade (Kondratyuk et al. 2014c). The genus Opeltia forms separate robust monophyletic branch within the Mikhtomia s.l. clade.

Oxneriopsis S. Y. Kondr., D. Upreti et J.-S. Hur, gen. nov. MycoBank nr.: MB 819653.

Similar to the genus Mikhtomia s. str., but differs in having more brownish orange to dark brown orange or even blackish brown-orange discs of apothecia and in forming separate robust monophyletic branch.

Type species: Oxneriopsis oxneri (S. Y. Kondr. et Søchting) S. Y. Kondr., D. Upreti et J.-S. Hur.

Thallus crustose, continuous to cracked or areolated, often forming vegetative propagules, phyllidia or schizidia; greyish or greenish grey, while por- 
tions with phyllidia and schizidia bright yellow or greenish yellow to dull yellow.

Apothecia lecanorine to zeorine, disc yellow, yellow-orange to orangebrown, dark brown or blackish brown; thalline margin as usual bright yellow; hymenium inspersed with oil; asci 8-spored; ascospores polarilocular, hyaline. Conidia bacilliform, $2.5-3(-3.5) \times 0.8-1 \mu \mathrm{m}$.

Chemistry: Fragilin (major) recorded for some taxa, however, chemistry of all taxa is not studied especially.

Ecology: It grows on bark of broad-leaved trees.

Distribution and species diversity: So far the genus includes Eastern Asian and North American taxa.

Etymology: It is named after the well-known Ukrainian lichenologist Alfred Mykolajovych Oxner (1898-1973) in recognition of his contribution to the Eurasian lichen flora.

Taxonomic notes and phylogenetic affinities: After ITS phylogeny species of genus Oxneriopsis were included into the genus Gyalolechia s.l. (Arup et al. 2013a). However, after combined phylogenetic analysis, based on nrITS, nrLSU and $\mathrm{mtSSU}$ sequences, the genus forms separate robust monophyletic branch within the Mikhtomia s.l. clade.

After molecular data hitherto available status of such species as Oxneriopsis oxneri and $O$. yeosuensis is confirmed within the genus. However, one more taxon (mentioned as O. aff yeosuensis) (see Fig. 2 and Appendix) is still under special revision and its status will be discussed separately.

It should be emphasised that within the genera Oxneriopsis and Mikhtomia we have the same tendency in forming phyllidia and schizidia, and two species Oxneriopsis oxneri and Mikhtomia subflavorubescens are sometimes morphologically totally the same. In this situation some specimens of Mikhtomia subflavorubescens were previously identified as "Caloplaca oxneri" (see Kondratyuk et al. 2014a) and superfluous combination "Mikhtomia oxneri" was proposed (Kondratyuk et al. 2014a). However, we should emphasise that combination was based on incorrectly identified specimens of Mikhtomia subflavorubescens and "M. oxneri" should be taken out from the usage. Correct place for this taxon is the Oxneriopsis branch. Fortunately Arup with colleagues (Arup et al. 2013a) have provided data on isotype specimens of the Caloplaca oxneri, and it allowed to clarify situation with real position of this taxon. After molecular data Oxneriopsis oxneri is very distinct, and appeared to be rather rare in South Korea for example (only a few specimens were confirmed as Oxneriopsis oxneri). At the same time Mikhtomia subflavorubescens is extremely common in this country, for which we have data more than 10 specimens, and almost half of specimens previously were incorrectly identified as "M. oxneri". However, they all are confirmed to be Mikhtomia subflavorubescens after molecular phylogeny. 
A separate paper on the molecular characters of the members of the genus Mikhtomia is still in progress (Kondratyuk et al. in prep.), however, some preliminary results are included here as proposals to new combinations (see below).

Unfortunately molecular data are still absent on such rare recently described taxon as 'Caloplaca' taranii S. Y. Kondr., S. I. Tchabanenko, I. Galanina et L. Yakovczenko (Kondratyuk et al. 2013a), which differs in forming confluent soredious mass, but in general very similar to Oxneriopsis oxneri. May be the future involving this taxon in molecular phylogeny of the Teloschistaceae will confirm its status inside of the Oxneriopsis branch.

After morphological data we would expect that another Eastern Asian taxon 'Caloplaca' kiewkaensis Yakovczenko, Galanina et S. Y. Kondr. (Kondratyuk et al. 2011), may also belong to this genus. However, we still do not have molecular data on this rare taxon.

It should be emphasised that in general the problem of molecular phylogeny of the Mikhtomia s.l. branch is that we do not have molecular data on the type species of the genus Mikhtomia, i.e. M. gordejevii, which was described in the 1920s and type specimen is very old. This species should be recollected in the type locality for the further extraction DNA and getting sequences for inclusion in the phylogenetic tree. In that case we will understand better importance of morphological and chemical characters for taxonomy of all genera of the Mikhtomia s.l. branch.

Teuvoahtiana S. Y. Kondr. et J.-S. Hur, gen. nov. MycoBank nr.: MB 819654.

In having lobate, areolate and squamulose representatives in the same robust monophyletic branch Teuvoahtiana is similar to the Australian genus Filsoniana of the Teloschistoideae, but differs in positioning in the subfamily Xanthorioideae.

Type species: Teuvoahtiana rugulosa (Nyl.) S. Y. Kondr. et J.-S. Hur.

Thallus crustose, areolate to squamulose, with rarely elongated in peripheral zone areoles to distinctly lobate; areolae and lobes usually very thick, convex, yellow-orange, dull yellowish brown to dull orange-brown, owing to numerous apothecia often dull reddish orange-brown; cortical layer paraplectenchymatous to mesodermatous paraplectenchymatous.

Apothecia of medium size to rather large, often densely aggregated, lecanorine to zeorine, disc plane, yellowish, roseus to pinkish orange-brown; true exciple of "textura intricata", asci (1-)2-4-6-8 spored, ascospores polaribilocular.

Chemistry is not studied in all members of this branch. 
Ecology: It grows on non-calcareous rocks.

Etymology: It is named after the well-known Finnish lichenologist Teuvo Ahti (H, Helsinki, Finland) in recognition of his contribution to lichenology and especially to development of lichenological investigation in the South American continent.

Distribution: So far all members of this genus are distributed only within the South American continent.

Taxonomic notes: After combined phylogenetic analysis it is positioned in the Xanthorioideae as separate robust monophyletic branch or in some cases as sister branch to the Xanthopeltis branch (Fig. 3). The genus includes three South American species after molecular data hitherto available.

Teuvoahtiana rugulosa (Nyl.) S. Y. Kondr. et J.-S. Hur and T. altoandiana (Malme) S. Y. Kondr. et J.-S. Hur, as well as T. fernandeziana (Zahlbr.) S. Y. Kondr. et J.-S. Hur were compared to each other in original descriptions as the closest or the most similar taxa (Malme 1926, Zahlbruckner 1917). Molecular data entirely confirm their close relations.

Among taxa mentioned we have had difficulties only with identification of specimen of Teuvoahtiana fernandeziana, because our specimen differs in having somewhat thicker, somewhat Toninia-like thallus. However, as far details on ascospores and apothecia are within the Teuvoahtiana fernandeziana diagnosis (Malme 1926, Zahlbruckner 1917) we still hesitate to produce new taxon name. However, further molecular studies should clarify if position of this species in the genus Teuvoahtiana is correct, and if identification of specimen cited will be supported by further molecular data.

There are only a few genera in the Teloschistaceae, where we have distinctly lobate and crustose (elobate) taxa in the same monophyletic branches, i.e. the Australian genus Filsoniana (Teloschistoideae) and genera Athallia, Gondwania, Orientophila and Teuvoahtiana from the Xanthorioideae. In this case the distinctly lobate taxa Filsoniana australiensis, Athallia scopularis, Orientophila subscopularis, O. yakjidoensis, O. jungakimae and Teuvoahtiana altoandina are members of genera, where major portion of species diversity of the genera mentioned is represented by crustose representatives. In the genus Gondwania the majority of species is lobate taxa, while crustose lichens are also present (Kondratyuk et al. 2014c).

However, it should be mentioned that last data on Orientophila shows that this genus is more heterogeneous and more diverse as it was thought before (Arup et al. 2013a, Kondratyuk et al. 2013b, 2016d) and probably in the future the genus Orientophila will contain larger number of crustose species, or it will be divided into two or more separate branches. Special revision of this genus is also in progress (Kondratyuk et al. 2017).

Additionally to Teuvoahtiana rugulosa, T. altoandina and T. fernandeziana there are also undescribed taxa as 'Caloplaca sp. 2' and 'Caloplaca sp. 4' (sensu 
Arup et al. 2013a), which belong to this monophyletic branch. However, they are still not legally described (not shown in the tree) unfortunately.

Arup with colleagues (Arup et al. 2013a) have recognised only Caloplaca altoandina and 4 undescribed taxa (mentioned as Caloplaca sp. 1-4), which were in sister position to the genus Xanthopeltis. After data of these authors monophyletic branch with Xanthopeltis has had high level of support, while C. altoandina did not have good support based on their matrix at that time. Taxa mentioned as Caloplaca sp. 1 and Caloplaca sp. 3 were included in this branch only after ITS phylogeny, while data on nrLSU and mtSSU were (and still are) missing.

Our data confirm previous data that Teuvoahtiana is closely related to the genera Xanthopeltis and Austroplaca. However, on another side, our data do not confirm previous data that Austroplaca is positioned in one clade with Gondwania and Cerothallia. The latter two genera are in somewhat out position to Xanthomendoza s.l. subphylum of the Xanthorioideae after our phylogenetic analysis.

Tomnashia S. Y. Kondr. et J.-S. Hur, gen. nov.

MycoBank nr.: MB 819655.

Similar to genus Blastenia of the subfamily Caloplacoideae, but differs in having often yellow to yellowish orange or apricot orange thallus and mainly orange apothecia, as well as forming separate robust monophyletic branch in the Xanthorioideae.

Type species: Tomnashia rosei (Hasse) S. Y. Kondr. et J.-S. Hur.

Thallus crustose, immersed into calcareous rock or absent, to continuous or areolate, white, grey, greenish yellow or yellowish orange to orange or apricot orange, in some taxa ( $T$. ludificans) with a waxy translucent appearance, without asexual propagules. Prothallus absent, or yellow-orange if present.

Apothecia small biatorine, disc orange to reddish brown; true exciple consisting of radiating hyphae, in basal portion of "textura intricata"; asci 8-spored; ascospores polarilocular, hyaline.

Chemistry: Parietin, fallacinal, emodin, teloschistin and parietinic acid.

Ecology: It grows on calcareous rock, on soil and on non-calcareous rocks.

Etymology: It is named after the well-known American lichenologist Thomas H. Nash III (1945-) in recognition of his contribution to lichenology, especially of the North American lichen flora.

Distribution: Species of this genus are hitherto known only from North America, where mainly distributed in the southwestern part of the continent.

The genus Tomnashia similarly to the genera Polycauliona s. str. and Igneoplaca S. Y. Kondr., Kärnefelt, Elix, A. Thell et J.-S. Hur of the Polycauliona s.l. subphylum has rather limited distribution in coastal southwestern North America, while the other genera of the Polycauliona s.l. subphylum, like Mass- 
jukiella S. Y. Kondr., Fedorenko, S. Stenroos, Kärnefelt, Elix, J.-S. Hur et A. Thell, Verrucoplaca S. Y. Kondr., Kärnefelt, Elix, A. Thell et J.-S. Hur, Scythioria S. Y. Kondr., Kärnefelt, Elix, A. Thell et J.-S. Hur are characterised by much wider distribution in the Northern Hemisphere or in the world.

Taxonomic notes and phylogenetic affiliations: After combined phylogenetic analysis the genus Tomnashia is positioned in the outermost position among monophyletic groups of the Polycauliona s.l. subclade (i.e. Verrucoplaca, Igneoplaca, Massjukiella) of the Xanthorioideae, which has rather low level of support (see tree Xanthorioideae), and in the most distant from the Polycauliona s. str. (i.e. P. coralloides) branch (Fig. 3 ).

From other members of the Polycauliona s.l. subphylum Tomnashia differs in having crustose, continuous, from immersed and indistinct to distinctly areolate thallus without elongated areoles at the margin, as well as mainly bright orange to reddish brown biatorine apothecia.

In having biatorine apothecia may be similar to the members of the genera Blastenia A. Massal. and Eilifdahlia S. Y. Kondr., Kärnefelt, Elix, A. Thell et J.-S. Hur, as well as of Laundonia S. Y. Kondr., L. Lőkös et J.-S. Hur and Mikhtomia S. Y. Kondr., Kärnefelt, Elix, A. Thell et J.-S. Hur of the subfamily Caloplacoideae, but the genus Tomnashia is positioned in separate robust monophyletic branch of the Xanthorioideae.

Additionally to Tomnashia rosei, T. nashii, T. luteominia and T. ludificans this branch includes also 'Polycauliona sp. 37' (after Arup et al. 2013a), but this taxon is still not described (and not included in the final tree).

Xanthaptychia S. Y. Kondr. et S. Ravera, gen. nov.

MycoBank nr.: MB 819656.

Similar to the genus Seirophora, but differs in having scleroplectenchymatous tissue in thallus and cortex of thalline margin of apothecia, and in distribution mainly in high altitude of mountainous regions of northern Eurasian or North American, as well as in forming separate robust monophyletic branch.

Type species: Xanthaptychia orientalis (Frödén) S. Y. Kondr. et S. Ravera.

Thallus foliosus to subfruticose or caespitose to pulvinate, usually rosette-forming, small; lobes dorsiventral, horizontally orientated and three different portions (main lobes, secondary lobules and terminal portions observed (see also Kondratyuk et al. 2013c)), or overlapping and often ascending, branching mostly irregular to anastomosing, rarely podetium-like; upper surface whitish grey, often brownish grey partly brownish yellow to yellow, lower side whitish grey; tomentum often well developed on upper surface; in 
section cortical layer scleroplectenchymatous; lower cortex absent or developed only on small portions; some taxa with various vegetative propagules.

Apothecia laminal, lecanorine, usually very large, to $5(-10) \mathrm{mm}$ diam., disc yellow, orange to reddish orange or brownish orange; cortex scleroplectenchymatous; asci 8-spored, polarilocular with narrow septa, hyaline; conidia narrowly bacilliform, 3-3.8 $\times 0.9-1 \mu \mathrm{m}$. [Note: data of Frödén and Litterski (2005) on conidia bacilliform to narrowly ellipsoid, (3-)3.5-4(4.5) $\times(1-) 1.4-$ $1.8(-2) \mu \mathrm{m}$ for Xanthaptychia orientalis are very doubtful and they are need in verifying].

Chemistry: Parietin (major) and low concentrations of emodin, fallacinal, teloschistin, parietinic acid and erythroglaucin.

Ecology: Corticolous species growing on Picea schrenkiana, Ephedra canisetina, Acer pubescens, A. regalis, Rhamnus sintesii, Pistacia vera, Sageretia laetevirens, Amygdalus buharica, and species of the genera Populus, Juniperus and Acer in montane belt between altitudes 1,100-2,100 m.

Etymology: It is named after similarities with members of the genus Anaptychia of the Physciaceae (i.e. lack of lower cortical layer) and xanthorioid lichens of the Teloschistaceae (in having foliose thallus).

Distribution: Northern Hemisphere with tendency to high altitudes of mountainous regions or polar latitudes of Eurasia and North America. Soredious taxa Xantaptychia contortuplicata and X. blumii supposed to have wider distribution than the esoredious species $X$. orientalis. However, the latter two taxa are rather recently described and we still have limited data on their distribution (see Kondratyuk et al. 2013c, 2015b, 2016b). In the Mediterranean region species of the genera Xantaptychia and Seirophora (i.e.: Xanthaptychia orientalis and Seirophora villosa) are completely allopatric.

Taxonomic notes and phylogenetic affiliations: After combined phylogenetic analysis the genus positioned in the Seirophora s.l. clade of the Caloplacoideae, where it is forming separate robust monophyletic branch (Fig. 2). From molecular data hitherto available the genus Xanthaptychia includes four species, i.e.: X. blumii, X. aurantiaca, X. contortuplicata and X. orientalis, while status of the other Seirophora species including S. scorigena, S. tenera and others is still waiting for clarifying.

Similar to the genus Seirophora, but differs in having scleroplectenchymatous tissue in thallus and cortex of thalline margin of apothecia (vs. prosoplectenchymatous), and in distribution mainly in high altitude of mountainous regions of northern Eurasian or North American (vs. Mediterranean region with preference to its western regions), as well as in forming separate robust monophyleric branch.

From 2013 the position of genus Seirophora in phylogenetic tree of the Teloschistaceae was somewhat questionable because in fact this genus was not 
confirmed by three gene phylogeny. Only data on ITS nrDNA were provided for the type species of this genus, i.e. S. villosa (Arup et al. 2013a). Within our study it was special task to provide missing data on nrLSU and mtSSU data for S. villosa. After getting these data (see Appendix and Fig. 2) it became clear that the Xanthaptychia branch formed a separate robust monophyletic branch.

The type species of this genus, Xanthaptychia orientalis appeared to be described twice almost in the same time by Frödén and Litterski (2005) and one year later by Kondratyuk and Kudratov (2006) as Xanthoanaptychia kotovii S. Y. Kondr. et Kudratov (while manuscripts of both publications were submitted in 2005, in the same year). Description of the Xanthoanaptychia kotovii was based on specimens kept in KW-L and LE and it was somewhat wider and more detailed than in the earlier paper. In this paper type species of the genus Xanthaptychia was compared with X. contortuplicata and Seirophora villosa, as well as with Massjukiella polycarpa (Hoffm.) S. Y. Kondr., Fedorenko, S. Stenroos, Kärnefelt, Elix, J.-S. Hur et A. Thell (Xanthorioideae) and Niorma chrysophthalma (L.) S. Y. Kondr., Kärnefelt, Elix, A. Thell, N.-H. Jeong et J.-S. Hur (Teloschistoideae). Unfortunately data on conidia of the type species of the genus Xanthaptychia are especially different and they are in urgent need of repeated revision (see above).

In both original papers similarities and differences with $S$. villosa and $S$. lacunosa were emphasised, as well as S. scorigena. However, after segregation of the genus Xanthaptychia in separate genus all these characters are in need of the further revision.

Status of Seirophora tenera Frödén et Litterski is still waiting for clarifying, while some information was published that data on ITS region of $S$. tenera were obtained (Frödén and Litterski 2005). However, these data are still not available for wide access.

\section{New combinations}

Elixjohnia bermaguiana (S. Y. Kondr. et Kärnefelt) S. Y. Kondr. et J.-S. Hur, comb. nova - MycoBank nr.: MB 819657 - Basionym: Caloplaca bermaguiana S. Y. Kondr. et Kärnefelt, in Kondratyuk, Kärnefelt, Elix and Thell, Bibl. Lichenol. 95: 348 (2007).

Elixjohnia gallowayi (S. Y. Kondr., Kärnefelt et Filson) S. Y. Kondr. et J.S. Hur, comb. nova - MycoBank nr.: MB 819658 - Basionym: Caloplaca gallowayi S. Y. Kondr., Kärnefelt et Filson, in Kondratyuk, Kärnefelt, Elix and Thell, Bibl. Lichenol. 95: 358 (2007).

Elixjohnia jackelixii (S. Y. Kondr., Kärnefelt et A. Thell) S. Y. Kondr. et J.S. Hur, comb. nova - MycoBank nr.: MB 819660 - Basionym: Caloplaca jackelixii S. Y. Kondr., Kärnefelt et A. Thell, in Kondratyuk, Kärnefelt, Elix and Thell, Bibl. Lichenol. 100: 251 (2009). 
Fominiella skii (Khodos., Vondrák et Šoun) S. Y. Kondr., D. Upreti et J.S. Hur, comb. nova - MycoBank nr.: MB 819661. - Basionym: Caloplaca skii Khodos., Vondrák et Šoun, in Vondrák, Khodosovtsev, Šoun and Vondráková, Lichenologist 44(1): 83 (2011) (2012). 三 Athallia skii (Khodos., Vondrák et Šoun) Arup, Frödén et Søchting (2013).

Gintarasiella aggregata (Kantvilas et S. Y. Kondr.) S. Y. Kondr. et J.-S. Hur, comb. nova - MycoBank nr.: MB 819697 - Basionym: Caloplaca aggregata Kantvilas et S. Y. Kondr., in Kantvilas, J. Adelaide Bot. Gard. 29: 56 (2016).

Hanstrassia lenae (Søchting et G. Figueras) S. Y. Kondr., comb. nova MycoBank nr.: MB 819662 - Basionym: Caloplaca lenae Søchting et G. Figueras, Lichenologist 39(1): 8 (2007). झ Gyalolechia lenae (Søchting et G. Figueras) Søchting, Frödén et Arup, Nordic J. Bot. 31(1): 71 (2013).

Ikaeria aurantiellina (Harm.) S. Y. Kondr., D. Upreti et J.-S. Hur, comb. nova - MycoBank nr.: MB 819663 - Basionym: Caloplaca aurantiellina Harm., in Pitard and Harmand, Bull. Soc. bot. Fr. 58 (Mém. no. 22): 46 (1911).

Klauderuiella aurantia (Pers.) S. Y. Kondr. et J.-S. Hur, comb. nova- MycoBank nr.: MB 819664 - Basionym: Lichen aurantius Pers., Ann. Bot. (Usteri) 5: 14 (1794). Variospora aurantia (Pers.) Arup, Frödén et Søchting, Nordic J. Bot. 31(1): 76 (2013).

Klauderuiella flavescens (Huds.) S. Y. Kondr. et J.-S. Hur, comb. novaMycoBank nr.: MB 819665 - Basionym: Lichen flavescens Huds., Fl. Angl.: 445 (1762). $\equiv$ Variospora flavescens (Huds.) Arup, Frödén et Søchting, Nordic J. Bot. 31(1): 76 (2013).

Klauderuiella thallincola (Wedd.) S. Y. Kondr. et J.-S. Hur, comb. nova - MycoBank nr.: MB 819666 - Basionym: Lecanora murorum var. thallincola Wedd., Mém. Soc. natn. Sci. nat. Cherbourg 19: 274 (1875). = Variospora thallincola (Wedd.) Arup, Frödén et Søchting, Nordic J. Bot. 31(1): 77 (2013).

Laundonia flavovirescens (Wulfen) S. Y. Kondr., L. Lőkös et J.-S. Hur, comb. nova - MycoBank nr.: MB 819667 - Basionym: Lichen flavovirescens Wulfen, Schr. Ges. naturf. Freunde, Berlin 8: 122 (1787). E Gyalolechia flavovirescens (Wulfen) Søchting, Frödén et Arup, Nordic J. Bot. 31(1): 70 (2013).

Laundonia persimilis (Wetmore) S. Y. Kondr., L. Lőkös et J.-S. Hur, comb. nova - MycoBank nr.: MB 819668 - Basionym: Caloplaca persimilis Wetmore, Bryologist 107(4): 513 (2004). = Gyalolechia persimilis (Wetmore) Søchting, Frödén et Arup, Nordic J. Bot. 31(1): 71 (2013).

Lazarenkoiopsis ussuriensis (Oxner, S. Y. Kondr. et Elix) S. Y. Kondr., L. Lőkös et J.-S. Hur, comb. nova - MycoBank nr.: MB 819695 - Basionym: Caloplaca ussuriensis Oxner, S. Y. Kondr. et Elix, Folia cryptog. Estonica 48: 21 (2011).

Nevilleiella marchantii (S. Y. Kondr. et Kärnefelt) S. Y. Kondr. et J.-S. Hur, comb. nova - MycoBank nr.: MB 819670 - Basionym: Caloplaca marchantii S. Y. Kondr. et Kärnefelt, in Kondratyuk, Kärnefelt, Elix and Thell, Bibl. Lichenol. 95: 367 (2007). 
Nevilleiella lateritia (Taylor) S. Y. Kondr. et J.-S. Hur, comb. nova- MycoBank nr.: MB 819671 - Basionym: Lecidea lateritia Taylor, J. Bot (Hooker) 6: 149 (1847). = Caloplaca lateritia (Taylor) Zahlbr., Cat. Lich. Univ. 7: 154 (1930).

Opeltia arizonica (H. Magn.) S. Y. Kondr. et L. Lőkös, comb. nova-MycoBank nr.: MB 819672 - Basionym: Caloplaca arizonica H. Magn., Bot. Notiser, p. 69 (1944). $\equiv$ Gyalolechia arizonica (H. Magn.) Søchting, Frödén et Arup, Nordic J. Bot. 31(1): 70 (2013)

Opeltia juniperina (Tomin) S. Y. Kondr. et L. Lőkös, comb. nova- MycoBank nr.: MB 819673 - Basionym: Caloplaca juniperina Tomin, Bot. Materialy (Notul. System. E Sect. Cryptog. Inst. Bot. nomine V. L. Komarovii Acad. Sci. URSS, 11: 11(1953). = Gyalolechia juniperina (Tomin) Søchting, Frödén et Arup, Nordic J. Bot. 31(1): 71 (2013).

Opeltia neobaltistanica (S. Y. Kondr. et J.-S. Hur) S. Y. Kondr. et L. Lőkös, comb. nova - MycoBank nr.: MB 819674 - Basionym: Caloplaca neobaltistanica S. Y. Kondr. et J.-S. Hur, in Kondratyuk, Lőkös, Farkas, Oh and Hur, Acta Bot. Hung. 57(1-2): 89 (2015).

Oxneriopsis oxneri (S. Y. Kondr. et Søchting) S. Y. Kondr., D. Upreti et J.S. Hur, comb. nova - MycoBank nr.: MB 819675 - Basionym: Caloplaca oxneri S. Y. Kondr. et Søchting, in Kondratyuk, Søchting and Kärnefelt, Nat. Hist. Res. 4(1): 17 (1996). इ Gyalolechia oxneri (S. Y. Kondr. et Søchting) Søchting, Frödén et Arup, Nordic J. Bot. 31(1): 71 (2013).

Oxneriopsis yeosuensis (S. Y. Kondr. et J.-S. Hur) S. Y. Kondr., D. Upreti et J.-S. Hur, comb. nova - MycoBank nr.: MB 819696 - Basionym: Caloplaca yeosuensis S. Y. Kondr. et J.-S. Hur, in Kondratyuk, Lőkös, Zarei-Darki, Haji Moniri, Tchabanenko, Galanina, Yakovchenko, Hooshmand, Ezhkin and Hur, Acta Bot. Hung. 55(1-2): 52 (2013) nom invalid., validated here - MB 819676 Type: South Korea, Jeollanam-do, Yeosu-si, Nam-myeon, Geumoh-do, Dumori, Jickpo coast, on rock, growing together with Caloplaca diffluens. Lat.: $34^{\circ} 30^{\prime}$ 45.00" N; Long.: $127^{\circ} 44^{\prime} 14.08^{\prime \prime}$ E; Alt.: 6 m a.s.l. Coll.: U. Jayalal et al. (120360), 26.04.2012. Holotype: KoLRI 015350; Isotypes: KoLRI 015346 (120357); KoLRI 015349 (120359); KoLRI 015325 (120336); KoLRI 015321 (120332); KoLRI 015369 (120380); KoLRI 015367 (120378); KoLRI 015359 (120370).

Squamulea micromera (Hue) S. Y. Kondr., L. Lőkös et J.-S. Hur, comb. nova - MycoBank nr.: MB 819677 - Basionym: Lecanora micromera Hue, Ann. Mycol. 13: 82 (1915). इ Caloplaca micromera (Hue) Zahlbr., Cat. Lich. Univers. 7: 157 (1931).- Type: [Japan], Mt Jizagatake prope Kofu, 07.1903 Urbain Faurie No 5651 (KYO 00031292 - isotype, designated here).

Teuvoahtiana altoandina (Malme) S. Y. Kondr. et J.-S. Hur, comb. nova - MycoBank nr.: MB 819678 - Basionym: Callopisma altoandinum Malme, Ark. Bot. 20A(9): 18 (1926). = Caloplaca altoandina (Malme) Zahlbr., Cat. Lich. Univers. 7: 211 (1931). 
Teuvoahtiana fernandeziana (Zahlbr.) S. Y. Kondr. et J.-S. Hur, comb. nova - MycoBank nr.: MB 819679 - Basionym: Blastenia fernandeziana Zahlbr., K. svenska Vetensk-Akad. Handl. 57(6): 46 (1917). = Caloplaca fernandeziana (Zahlbr.) Follmann et Redón, Willdenowia 6(3): 448 (1972).

Teuvoahtiana rugulosa (Nyl.) S. Y. Kondr. et J.-S. Hur, comb. nova- MycoBank nr.: MB 819680 - Basionym: Placodium rugulosum Nyl., Annls Sci. Nat., Bot., sér. 4, 3: 153 (1855). = Caloplaca rugulosa (Nyl.) Zahlbr., Cat. Lich. Univers. 7: 263 (1931).

Tomnashia ludificans (Arup) S. Y. Kondr. et J.-S. Hur, comb. nova-MycoBank nr.: MB 819681 - Basionym: Caloplaca ludificans Arup, Bryologist 98(1): 107 (1995). Polycauliona ludificans (Arup) Arup, Frödén et Søchting, Nordic J. Bot. 31(1): 52 (2013).

Tomnashia luteominia (Tuck.) S. Y. Kondr. et J.-S. Hur, comb. nova-MycoBank nr.: MB 819682 - Basionym: Placodium luteominium Tuck. (as 'luteominium'), Lichens of California (Berkeley): 18 (1866). = Polycauliona luteominia (Tuck.) Arup, Frödén et Søchting, Nordic J. Bot. 31(1): 52 (2013).

Tomnashia nashii (Nav.-Ros., Gaya et Hladún) S. Y. Kondr. et J.-S. Hur, comb. nova - MycoBank nr.: MB 819683 - Basionym: Caloplaca nashii Nav.-Ros., Gaya et Hladún, Mycotaxon 79: 31 (2001). = Polycauliona nashii (Nav.-Ros., Gaya et Hladún) Arup, Frödén et Søchting, Nordic J. Bot. 31(1): 53 (2013).

Tomnashia rosei (Hasse) S. Y. Kondr. et J.-S. Hur, comb. nova-MycoBank nr.: MB 819684 - Basionym: Caloplaca rosei Hasse, Bryologist 14: 102 (1911). $\equiv$ Polycauliona rosei (Hasse) Arup, Frödén et Søchting, Nordic J. Bot. 31(1): 53 (2013).

Variospora latzelii (Servít) S. Y. Kondr., comb. nova - MycoBank nr.: MB 819685 - Basionym: Blastenia latzelii Servít (as 'latzeli'), Hedwigia 74: 151 (1934). $\equiv$ Caloplaca latzelii (Servít) Clauzade et Cl. Roux, Bull. Soc. bot. CentreOuest, Nouv. sér., num. spec. 7: 824 (1985).

Xanthaptychia aurantiaca (R. Br.) S. Y. Kondr. et S. Ravera, comb. nova - MycoBank nr.: MB 819686 - Basionym: Borrera aurantiaca R. Br., Suppl. to the Appendix of Cpt. Parrys Voyag., Nat. Hist.: CCCV (1824). $\equiv$ Seirophora aurantiaca (R. Br.) Frödén, in Frödén et Lassen, Lichenologist 36(5): 295 (2004).

Xanthaptychia blumii (S. Y. Kondr. et Moniri) S. Y. Kondr. et S. Ravera, comb. nova - MycoBank nr.: MB 819785 - Basionym: Seirophora blumii S. Y. Kondr. et Moniri, in Kondratyuk, Lőkös, Tschabanenko, Moniri and Farkas, Acta Bot. Hung. 55(3-4): 275-349 (2013).

Xanthaptychia contortuplicata (Ach.) S. Y. Kondr. et S. Ravera, comb. nova - MycoBank nr.: MB 819688 - Basionym: Parmelia contortuplicata Ach., Syn. meth. lich. (Lund): 210 (1814). = Seirophora contortuplicata (Ach.) Frödén, in Frödén and Lassen, Lichenologist 36(5): 297 (2004).

Xanthaptychia orientalis (Frödén) S. Y. Kondr. et S. Ravera, comb. novaMycoBank nr.: MB 819689 - Basionym: Seirophora orientalis Frödén, in Frödén 
and Litterski, Graphis Scripta 17(1): 22 (2005). = Xanthoanaptychia kotovii S. Y. Kondr. et Kudratov, Ukr. Botan. Zh. 63(3): 342 (2006).

Xanthocarpia raesaenenii (Bredkina) S. Y. Kondr., comb. nova- MycoBank nr.: MB 819690 - Basionym: Caloplaca raesaenenii Bredkina, Nov. sist. Niz. Rast. 23: 170 (1986). - Replaced synonym: Placodium geophilum Räsänen, Ann. bot. Soc. Zool.-Bot. fenn. Vanamo 12(1): 1 (1938), Nom. illegit., Art. 53.1 non Placodium geophilum Th. Fr. (1891).

\section{CONCLUSIONS}

Seventeen newly discovered robust monophyletic branches proved by combined phylogenetic analysis based on ITS nr DNA, 28S nrLSU and 12S $\mathrm{mtSSU}$, which are proposed to consider as separate genera are added to the subfamilies Teloschistoideae (5), Caloplacoideae (7), Xanthorioideae (3) and Brownlielloideae (1). There are also genera Fominiella and Ikaeria, which are positioned in out position to known subfamilies and possibly illustrate that additional subfamilies of the Teloschistaceae still exist and are waiting for legal description.

Acknowledgements - We are thankful to Ingvar Kärnefelt and Arne Thell (both Lund, Sweden) for kind help with checking some names, and comments to some taxa, to Anna Guttová (Bratislava, Slovak Republic), Lidia Yakovchenko (Vladivostok, Russia) and Gintaras Kantvilas (Hobart, Tasmania) for providing fresh collections, to curator of KYO herbarium for the loan of type specimens, and to Konstanze Bensch (The MycoBank Team, UK) for valuable nomenclatural comments and help. SK and LL are grateful to Prof. J.-S. Hur and Dr S.-O. Oh for assistance and support during visits to South Korea in 2014, 2015 and 2016. The project was supported by the Ministry of Education and Science of Ukraine (M/902015-285 and M/34-2016-285) and by the Korean Brain Pool Program (161S-4-3-1659) for SK, and the Korea National Research Resource Center Program, the Korean Forest Service Program (KNA 2012-2016) through the Korea National Arboretum, and (for LL) also by the Hungarian Scientific Research Fund (OTKA K81232).

\section{REFERENCES}

Arup, U. (2006): A new taxonomy of the Caloplaca citrina group in the Nordic countries, except Iceland. - Lichenologist 38(1): 1-20. https://doi.org/10.1017/S0024282905005402 Arup, U. (2009): The Caloplaca holocarpa group in the Nordic countries, except Iceland. Lichenologist 41(2): 111-130. https://doi.org/10.1017/s0023282909008135

Arup, U. and Grube, M. (1999): Where does Lecanora demissa (Ascomycota, Lecanorales) belong? - Lichenologist 31: 419-430. https://doi.org/10.1017/s0024282999000584

Arup, U., Søchting, U. and Frödén, P. (2013a): A new taxonomy of the family Teloschistaceae. - Nordic J. Bot. 31: 16-83. https://doi.org/10.1111/j.1756-1051.2013.00062.x

Arup, U., Søchting, U. and Frödén, P. (2013b): Addendum to 'A new taxonomy of the family Teloschistaceae'. Nordic J. Bot. 31: 256. https://doi.org/10.1111/j.1756-1051.2013.00295.x 
Clauzade, G. and Roux, C. (1985): Likenoj de Okcidenta Eŭropo. Illustrata determinlibro. Bull. Soc. bot. Centre-Ouest, Royan 7: 1-893.

Ekman, S. (1999): PCR optimization and troubleshooting, with special reference to the amplification of ribosomal DNA in lichenized fungi. - Lichenologist 31(5): 517-531. https://doi.org/10.1017/s0024282999000675

Fedorenko, N. M., Stenroos, S., Thell, A., Kärnefelt, I. and Kondratyuk, S. Y. (2009): A phylogenetic analysis of xanthorioid lichens (Teloschistaceae, Ascomycota) based on ITS and mtSSU sequences. - Bibl. Lichenol. 100: 49-84.

Fedorenko, N. M., Stenroos, S., Thell, A., Kärnefelt, I., Elix, J. A., Hur, J. S. and Kondratyuk, S. Y. (2012): Molecular phylogeny of xanthorioid lichens (Teloschistaceae, Ascomycota), with notes on their morphology. - Bibl. Lichenol. 108: 45-64.

Frödén, P. and Lassen, P. (2004): Typification and emendation of Seirophora Poelt to include species segregated from Teloschistes Norman. - Lichenologist 36: 289-298. https://doi.org/10.1017/S002428290401432X

Frödén, P. and Litterski, B. (2005): Two new species of Seirophora from central Asia. - Graphis Scripta 17: 22-26.

Gardes, M. and Bruns, T. D. (1993): ITS primers with enhanced specificity for basidiomycetes - application to the identification of mycorrhizae and rusts. - Mol. Ecol. 2: 113118. https://doi.org/10.1111/j.1365-294x.1993.tb00005.x

Gaya, E., Lutzoni, F., Zoller, S. and Navarro-Rosinés, P. (2003): Phylogenetic study of Fulgensia and allied Caloplaca and Xanthoria species (Teloschistaceae, lichen-forming Ascomycota). - Amer. J. Bot. 90(7): 1095-1103. https://doi.org/10.3732/ajb.90.7.1095

Gaya, E., Navarro-Rosinés, P., Llimona, X., Hladun, N. and Lutzoni, F. (2008): Phylogenetic reassessment of the Teloschistaceae (lichen-forming Ascomycota, Lecanoromycetes). - Mycol. Res. 112(5): 528-546. https://doi.org/10.1016/j.mycres.2007.11.005

Gaya, E., Högnabba, F., Holguin, Á., Molnár, K., Fernández-Brime, S., Stenroos, S., Arup, U., Søchting, U., van den Boom, P., Lücking, R., Sipman, H. J. M. and Lutzoni, F. (2012): Implementing a cumulative supermatrix approach for a comprehensive phylogentic study of the Teloschistales (Pezizomycotina, Ascomycota). - Mol. Phyl. Evol. 63: 374-387. https://doi.org/10.1016/j.ympev.2012.01.012

Gaya, E., Fernández-Brime, S., Vargas, R., Lachlan, R. F., Gueidan, C., Ramírez-Mejía, M. and Lutzoni, F. (2015): The adaptive radiation of lichen-forming Teloschistaceae is associated with sunscreening pigments and a bark-to-rock substrate shift. - Proc. Nat. Acad. Sci. USA 112(37): 11600-11605. https://doi.org/10.1073/pnas.1507072112

Joshi, Y., Vondrák, J., Vondrákova, O., Nguyen, T. T. and Hur, J.-S. (2011): Caloplaca allochroa (lichenized Ascomycetes), a new saxicolous lichen species from South Korea. - Mycotaxon 117: 261-267. https://doi.org/10.5248/117.261

Kantvilas, G. (2016): A synopsis and key for the lichen genus Caloplaca (Teloschistaceae) on Kangaroo Island, with the description of two new species. - J. Adelaide Bot. Gard. 29: 53-69.

Kärnefelt, I. (1989): Morphology and phylogeny in the Teloschistales. - Cryptogamic Botany 1: 147-203.

Kondratyuk, S., Søchting, U. and Kärnefelt, I. (1996): Caloplaca oxneri (Teloschistaceae), a new lichen species from East Asia. - Nat. Hist. Res. 4: 17-20.

Kondratyuk, S. Y., Elix, J. A., Galanina, I. A., Yakovchenko, L. S., Kärnefelt, I. and Thell, A. (2011): Four new Caloplaca species (Teloschistaceae, Ascomycotina). - Folia Cryptog. Est. 48: 17-23.

Kondratyuk, S. and Kudratov, I. (2003): Three new Caloplaca species from Asia. - Ukr. Bot. Zhurn. 60(1): 65-69. 
Kondratyuk, S. and Kudratov, I. (2006): To revision of Middle Asian material of the 'Teloschistes brevior' complex (Teloschistaceae). - Ukr. Bot. Zhurn. 63(3): 340-350.

Kondratyuk, S., Kärnefelt, I., Elix, J. A. and Thell, A. (2007): New species of the genus Caloplaca in Australia. - Bibl. Lichenol. 95: 341-386.

Kondratyuk, S. Y., Kärnefelt, I., Elix, J. A. and Thell, A. (2009): Contributions to the Teloschistaceae, with particular reference to the Southern Hemisphere. - Bibl. Lichenol. 100: 207-282.

Kondratyuk, S. Y., Elix, J. A., Kärnefelt, I. and Thell, A. (2012): An artificial key to Australian Caloplaca species (Teloschistaceae, Ascomycota). - Bibl. Lichenol. 108: 141-160.

Kondratyuk, S. Y., Lőkös, L., Zarei-Darki, B., Haji Moniri, M., Tchabanenko, S. I., Galanina, I., Yakovchenko, L., Hooshmand, F., Ezhkin, A. K. and Hur, J.-S. (2013a): Five new Caloplaca species (Teloschistaceae, Ascomycota) from Asia. - Acta Bot. Hung. 55: 4160. https://doi.org/10.1556/ABot.55.2013.1-2.4

Kondratyuk, S., Jeong, M. H., Yu, N. H., Kärnefelt, I., Thell, A., Elix, J. A., Kim, J., Kondratyuk, A. S. and Hur, J.-S. (2013b): Four new genera of teloschistoid lichens (Teloschistaceae, Ascomycota) based on molecular phylogeny. - Acta Bot. Hung. 55: 251274. https://doi.org/10.1556/ABot.55.2013.3-4.8

Kondratyuk, S., Lőkös, L., Tschabanenko, S., Haji Moniri, M., Farkas, E., Wang, X. Y., Oh, S.-O. and Hur, J.-S. (2013c): New and noteworthy lichen-forming and lichenicolous fungi. - Acta Bot. Hung. 55: 275-349. https://doi.org/10.1556/ABot.55.2013.3-4.9

Kondratyuk, S. Y., Jeong, M. H., Yu, N. N., Kärnefelt, I., Thell, A., Elix, J. A., Kim, J., Kondratiuk, A. S. and Hur, J.-S. (2014a): A revised taxonomy for the subfamily Caloplacoideae (Teloschistaceae, Ascomycota) based on molecular phylogeny. - Acta Bot. Hung. 56: 93-123. https://doi.org/10.1556/ABot.56.2014.1-2.10

Kondratyuk, S. Y., Lőkös, L., Tschabanenko, S., Skirina, I., Galanina, I., Oh, S.-O. and Hur, J.-S. (2014b): Caloplaca kedrovopadensis sp. nova and some new lichens from the Primorsky region, Russia. - Acta Bot. Hung. 56: 125-140. https://doi.org/10.1556/ ABot.56.2014.1-2.11

Kondratyuk, S. Y., Kärnefelt, I., Thell, A., Elix, J. A., Kim, J., Jeong, M. H., Yu, N. H., Kondratiuk, A. S. and Hur, J.-S. (2014c): A revised taxonomy of the subfamily Xanthorioideae (Teloschistaceae, Ascomycota) based on molecular phylogeny. - Acta Bot. Hung. 56: 141-178. https://doi.org/10.1556/ABot.56.2014.1-2.12

Kondratyuk, S. Y., Kärnefelt, I., Thell, A., Elix, J. A., Kim, J., Kondratiuk, A. S. and Hur, J.-S. (2015a): Tassiloa, a new genus in the Teloschistaceae (lichenized Ascomycetes). - Graphis Scripta 27: 22-26.

Kondratyuk, S. Y., Lőkös, L., Farkas, E., Oh, S.-O. and Hur, J.-S. (2015b): New and noteworthy lichen-forming and lichenicolous fungi, 2. - Acta Bot. Hung. 57(1-2): 77-141. https://doi.org/10.1556/ABot.57.2015.1-2.10

Kondratyuk, S. Y., Lőkös, L., Kim, J. A., Kondratiuk, A. S., Jeong, M. H., Jang, S. H., Oh, S.-O. and Hur, J.-S. (2015c): Three new monotypic genera of the caloplacoid lichens (Teloschistaceae, lichen-forming Ascomycetes). - Mycobiology 43: 195-202. https:// doi.org/10.5941/myco.2015.43.3.195

Kondratyuk, S. Y., Kärnefelt, I., Thell, A., Elix, J. A., Kim, J., Kondratiuk, A. S. and Hur, J.-S. (2015d): Brownlielloideae, a new subfamily in the Teloschistaceae (Lecanoromycetes, Ascomycota). - Acta Bot. Hung. 57: 321-341. https://doi.org/10.1556/034.57.2015.3-4.6

Kondratyuk, S. Y., Kim, J. A., Yu, N.-H., Jeong, M.-H., Jang, S. H., Kondratiuk, A. S., Zarei-Darki, B. and Hur, J.-S. (2015e): Zeroviella, a new genus of xanthorioid lichens (Teloschistaceae, Ascomycota) proved by three gene phylogeny. - Ukr. Bot. J. 72(6): 574-584. https://doi.org/10.15407/ukrbotj72.06.574 
Kondratyuk, S. Y., Kärnefelt, I., Thell, A., Elix, J. A., Kim, J. A., Kondratiuk, A. S. and Hur, J.-S. (2015f): Ovealmbornia reginae (Teloschistaceae, Ascomycetes), a new xanthorioid lichen from South Africa. - Herzogia 28: 465-472. https://doi.org/10.13158/heia. 28.2.2015.465

Kondratyuk, S. Y., Lőkös, L., Halda, J. P., Haji Moniri, M., Farkas, E., Park, J. S., Lee, B. G., Oh, S.-O. and Hur, J.-S. (2016a): New and noteworthy lichen-forming and lichenicolous fungi 4. - Acta Bot. Hung. 58(1-2): 75-136. https://doi.org/10.1556/034.58.2016.1-2.4

Kondratyuk, S. Y., Lőkös, L., Halda, J. P., Upreti, D. K., Mishra, G. K., Haji Moniri, M., Farkas, E., Park, J. S., Lee, B. G., Liu, D., Woo, J. J., Jayalal, R. G. U., Oh, S.-O. and Hur, J.-S. (2016b): New and noteworthy lichen-forming and lichenicolous fungi 5. - Acta Bot. Hung. 58(3-4): 319-396. https://doi.org/10.1556/ABot.58.2016.3-4.7

Kondratyuk, S. Y., Lőkös, L., Kim, J. A., Kondratiuk, A. S., Jeong, M.-H., Jang, S. H., Oh, S.-O., Wang, X. Y. and Hur, J.-S. (2016c): Fauriea, a new genus of the lecanoroid caloplacoid lichens (Teloschistaceae, lichen-forming Ascomycetes). - Acta Bot. Hung. 58(3-4): 303-318. https://doi.org/10.1556/ABot.58.2016.3-4.6

Kondratyuk, S. Y., Lőkös, L., Kärnefelt, I., Thell, A., Elix, J. A., Oh, S.-O. and Hur, J.-S. (2016d): Three new Orientophila species (Teloschistaceae, Ascomycota) from Eastern Asia. - Graphis Scripta 28(1-2): 50-58.

Kondratyuk, S. Y., Lőkös, L., Halda, J. P., Roux, C., Upreti, D. K., Schumm, F., Mishra, G. K., Nayaka, S., Farkas, E., Park, J. S., Lee, B. G., Liu, D., Woo, J.-J. and Hur, J.-S. (2017): New and noteworthy lichen-forming and lichenicolous fungi 6. - Acta Bot. Hung. 59(1-2): 137-260. https://doi.org/10.1556/034.59.2017.1-2.7

Llimona, X. and Werner, R. G. (1975): Quelques lichens nouveau ou interessants de la Sierra de Gata (Almeria, SE de l'Espagne). - Acta Phytotax. Barcinonensia 16: 1-32.

Lutzoni, F., Pagel, M. and Reeb, V. (2001): Major fungal lineages are derived from lichen symbiotic ancestors. - Nature 411(6840): 937-940. https://doi.org/10.1038/35082053

Malme, G. O. A. (1926): Lichenes blasteniospori Herbarii Regnelliani. - Ark. Bot. 20A(9): 1-51.

Martin, M. P. and Winka, K. (2000): Alternative methods of extracting and amplifying DNA from lichens. - Lichenologist 32: 189-196. https://doi.org/10.1006/lich.1999.0254

Søchting, U. and Figueras, G. (2007): Caloplaca lenae sp. nov. and other Caloplaca species with caloploicin and vicanicin. - Lichenologist 39(1): 7-14. https://doi.org/10.1017/ s0024282907006299

Søchting, U., Søgaard, M. Z., Elix, J. A., Arup, U., Elvebakk, A. and Sancho, L. G. (2014a): Catenarina (Teloschistaceae, Ascomycota), a new Southern Hemisphere genus with 7-chlorocatenarin. - Lichenologist 46: 175-187. https://doi.org/10.1017/s002428291300087x

Søchting, U., Garrido-Benavent, I., Seppelt, R., Castello, M., Pérez-Ortega, S., De Los Ríos Murillo, A., Sancho, L. G., Frödén, P. and Arup, U. (2014b): Charcotiana and Amundsenia, two new genera in Teloschistaceae (lichenized Ascomycota, subfamily Xanthorioideae) hosting two new species from continental Antarctica, and Austroplaca frigida, a new name for a continental Antarctic species. - Lichenologist 46: 763-782. https://doi.org/10.1017/s0024282914000395

Steiner, J. (1911): Adnotationes lichenographicae. - Österr. Bot. Zeitschr. 61: 177-183, 223-225. Swofford, D. L. (2003). PAUP*, Phylogenetic analysis using parsimony (*and other methods). Sunderland, Sinauer Associates, Massachusetts.

Tamura, K., Peterson, D., Peterson, N., Stecher, G., Nei, M. and Kumar, S. (2011): MEGA5: molecular evolutionary genetics analysis using maximum likelihood, evolutionary distance, and maximum parsimony methods. - Mol. Biol. Evol. 28: 2731-2739. https:// doi.org/10.1093/molbev/msr121 
van den Boom, P. P. G. and Etayo, J. (2006): New records of lichens and lichenicolous fungi from Fuerteventura (Canary Islands), with descriptions of some new species. - Cryptogamie, Mycol. 27(4): 341-374.

Vilgalys, R. and Hester, M. (1990): Rapid genetic identification and mapping of enzymatically amplified ribosomal DNA from several Cryptococcus species. - J. Bacteriol. 172(8): 4238-4246.

Vondrák, J., Khodosovtsev, A., Šoun, J. and Vondráková, O. (2011): Two new European species from the heterogeneous Caloplaca holocarpa group (Teloschistaceae). - $\mathrm{Li}$ chenologist 44(1): 73-89. https://doi.org/10.1017/S0024282911000636

Vondrák, J., Šoun, J., Sogaard, M., Søchting, U. and Arup, U. (2010): Caloplaca phlogina, a lichen with two facies: an example of infraspecific variability resulting in the description of a redundant species. - Lichenologist 42: 685-692. https://doi.org/10.1017/ S0024282910000435

Vondrák, J., Šoun, J., Vondráková, O., Fryday, A. M., Khodosovtsev, A. and Davydov, E. (2012): Absence of anthraquinone pigments is paraphyletic and a phylogenetically unreliable character in the Teloschistaceae. - Lichenologist 44: 401-418. https://doi. org/10.1017/s0024282911000843

Wetmore, C. M. (2003): The Caloplaca squamosa group in North and Central America. Bryologist 106(1): 147-156. https://doi.org/10.1639/0007-2745(2003)106[0147:tcsgin]2.0 .co;2

Wetmore, C. (2007): Caloplaca. - In: Nash III, T. H., Gries, C. and Bungartz, F. (eds): Lichen flora of the Greater Sonoran Desert Region. 3. Arizona State University, Lichens Unlimited, Tempe, pp. 179-220.

White, T. J., Bruns, T., Lee, S. and Taylor, J. (1990): Amplification and direct sequencing of fungal ribosomal RNA genes for phylogenetics. - PCR Protocols 38: 315-322. https:// doi.org/10.1016/b978-0-12-372180-8.50042-1

Zahlbruckner, A. (1917): Botanische Ergebnisse der schwedischen Expedition nach Patagonien und dem Feuerlande 1907-1909. VI. Die Flechten. - Kongl. Svenska vetensk.-Akad. Handl. 57: 1-62.

\section{APPENDIX}

Specimens included in the phylogenetic analysis with GenBank accession numbers. Newly submitted sequences are given in bold. Abbreviation: ${ }^{*}=$ this paper

\begin{tabular}{|c|c|c|c|c|}
\hline Species name & References / voucher details & ITS & LSU & $\mathrm{mtSSU}$ \\
\hline Amundsenia approximata & Søchting et al. (2014) & KJ789964 & KJ789972 & $\overline{\text { KJ789974 }}$ \\
\hline Amundsenia approximata & Søchting et al. (2014) & KJ789963 & & \\
\hline Athallia holocarpa & $\operatorname{Arup}(2009)$ & FJ346539 & & \\
\hline Athallia holocarpa & Arup et al. (2013a) & & KC179148 & KC179478 \\
\hline Athallia scopularis & Arup et al. (2013a) & КC179339 & KC179150 & КC179480 \\
\hline Austroplaca ambitiosa & Arup et al. (2013a) & KC179081 & KC179151 & KC179481 \\
\hline Blastenia ferruginea & Arup et al. $(2013 a)$ & KC179416 & KC179163 & КC179493 \\
\hline Brigantiaea ferruginea & Kondratyuk et al. (2013b); SK-779 & KF264622 & & KF264684 \\
\hline Brigantiaea ferruginea & Kondratyuk et al. (2013b); SK-780 & KF264623 & & KF264685 \\
\hline \multirow[t]{2}{*}{ Brigantiaea ferruginea } & *South Korea, 06.07.2012, & & & \\
\hline & Kondratyuk, S. Y. (121967), KoLRI 16922 & KY614393 & & \\
\hline Brigantiaea ferruginea & *South Korea, 06.07.2012, & KY614394 & & \\
\hline \multirow{2}{*}{ Brigantiaea ferruginea } & *South Korea, 06.07.2012, Kondratyuk, & & & \\
\hline & S. Y. (121981), KoLRI 16936 & KY614395 & & \\
\hline Brownliella kobeana & Kondratyuk et al. (2015d); 120032, KoLRI & KT456212 & KT456227 & KT456242 \\
\hline
\end{tabular}




\begin{tabular}{|c|c|c|c|c|}
\hline Species name & References / voucher details & ITS & LSU & $\mathrm{mtSSU}$ \\
\hline Brownliella kobeana & Kondratyuk et al. (2015d); 130231, KoLRI & KT456213 & KT456228 & KT456243 \\
\hline Brownliella kobeana & Kondratyuk et al. $(2015 d) ; 130318$, KoLRI & KT456214 & KT456229 & KT456244 \\
\hline Bryoplaca sinapisperma & Arup et al. $(2013 a)$ & КС179421 & & KC179495 \\
\hline Calogaya biatorina & Gaya et al. (2008) & EU639634 & & \\
\hline Calogaya aff. lobulata & Kondratyuk et al. (2014c); SK-803 & KJ133448 & KJ133487 & KJ133506 \\
\hline Calogaya aff. lobulata & Kondratyuk et al. (2014c); SK-804 & KJ133449 & KJ133488 & KJ133507 \\
\hline Calogaya aff. lobulata & Kondratyuk et al. (2014c); SK-805 & KJ133450 & KJ133489 & KJ133508 \\
\hline Calogaya mogoltanica & Kondratyuk et al. (2014c); SK-256 & KJ133452 & KJ133491 & KJ133509 \\
\hline Calogaya mogoltanica & Kondratyuk et al. (2014c); SK-257 & KJ133453 & KJ133492 & KJ133510 \\
\hline Caloplaca cerina & Fedorenko et al. (2009, 2012); FNM-185 & EU681284 & & EU680863 \\
\hline Caloplaca cerina & Gaya et al. (2012) & & JQ301549 & \\
\hline Caloplaca pelodella & Kondratyuk et al. (2013b); SK-714 & KF264629 & & KF264689 \\
\hline Caloplaca stillicidiorum & Gaya et al. (2008) & EU639607 & & \\
\hline Catenarina desolata & Søchting et al. (2014) & KF657317 & & KF657319 \\
\hline Cerothallia luteoalba & Arup et al. (2013a) & KC179099 & КC179177 & KC179511 \\
\hline Cerothallia yarraensis & Kondratyuk et al. (2014c); SK-890, isotype & KJ133454 & KJ133493 & KJ133511 \\
\hline Charcotiana antarctica & Søchting et al. (2014) & KJ789971 & KJ789973 & KJ789976 \\
\hline Charcotiana antarctica & Søchting et al. (2014) & KJ789968 & & \\
\hline Dijigiella kaernefeltiana & $\begin{array}{l}\text { *SK-969, Australia, 07.01. 2004, Kärnefelt, } \\
\text { I. 20042002; LD 1238056, holotype }\end{array}$ & KY614396 & KY614444 & KY614475 \\
\hline Dijigiella kaernefeltiana & $\begin{array}{l}\text { *SK-970, Australia, 07.01. 2004, Kärnefelt, } \\
\text { I. 20042002; LD 1238056, holotype }\end{array}$ & KY614397 & KY614445 & KY61 \\
\hline Dijigiella subaggregata & *SK-955, Australia: Victoria, 23.01.1999, & & & \\
\hline & D 1275974, holotype & KY614398 & $\begin{array}{l}\text { KY614446 } \\
\text { KC179357 }\end{array}$ & $\begin{array}{l}\text { KY614477 } \\
\text { KC179183 }\end{array}$ \\
\hline $\begin{array}{l}\text { Dufourea flammea } \\
\text { Dufourea flammea }\end{array}$ & Arup et al. (2013) & FU681316 & & $\begin{array}{l}\text { KC179183 } \\
\text { EU680898 }\end{array}$ \\
\hline $\begin{array}{l}\text { Dufourea flammea } \\
\text { Dufourea flammea }\end{array}$ & ; FNM- & EU681315 & & EU680897 \\
\hline Eilifdahlia dahlii & 56 & KJ021221 & KJ021252 & KJ021277 \\
\hline Eilifdahlia dahlii & k et al. (2 & KJ021318 & KJ021253 & KJ021279 \\
\hline Eilifdahlia wirthii & uk et al. (2014a); SK-262 & KJ021319 & KJ021254 & KJ021280 \\
\hline Elenkiniana ehrenbergii & ig and Figueras (2007) & DQ888715 & & \\
\hline Elenkiniana gloriae & $4 a) ;$ SK-750 & KJ021323 & & \\
\hline Elenkiniana gloriae & 14a); SK-611 & KJ021321 & KJ021256 & KJ021282 \\
\hline Elenkiniana gloriae & Kondratyuk et al. (2014a); SK-613 & KJ021322 & & KJ021283 \\
\hline Elixjohnia bermaguiana & $\begin{array}{l}\text { Kondratyuk et al. (2013c, as Sirenophila } \\
\text { bermaguiana); SK- } 979\end{array}$ & & & KF264706 \\
\hline Elixjohnia bermaguiana & $\begin{array}{l}\text { Arup et al. (2013a, as Sirenophila } \\
\text { bermaguiana); isotype }\end{array}$ & КC179299 & KC179245 & KC179584 \\
\hline Elixjohnia gallowayi & $\begin{array}{l}\text { Arup et al. (2013a, as Sirenophila } \\
\text { gallowayi); isotype }\end{array}$ & КC179301 & KC179247 & KC17958 \\
\hline Elixjohnia jackelixii & $\begin{array}{l}\text { Kondratyuk et al. (2013c, as Sirenophila } \\
\text { jackelixii); SK-910 }\end{array}$ & KF264655 & KF264683 & KF264707 \\
\hline Elixjohnia jackelixii & $\begin{array}{l}\text { Kondratyuk et al. (2013b, as Sirenophila } \\
\text { jackelixii); SK-911 }\end{array}$ & & & KF264708 \\
\hline Elixjohniaj & Arup et al. $(2013 a$, as Sirenophila jackelixii) & КC179303 & КC179248 & KC179587 \\
\hline Fauriea chujaensis & Kondratyuk et al. (2016c); SK-D07, isotype & KX793097 & KX793100 & KX793103 \\
\hline Fauriea orientochinensis & 16c); SK-709 & KX793095 & KX793098 & KX793101 \\
\hline ntochinensis & et al. (2016c); SK-710 & KX793096 & KX793099 & KX793102 \\
\hline Filsoniana australiensis & ratyuk et al. (2013c); SK-751 & KF264631 & KF264665 & KF264691 \\
\hline Flavoplaca citrina & Arup (2006) & DG173224 & & \\
\hline Flavoplaca citrina & Arup et al. $(2013 a)$ & & KC179186 & КC179521 \\
\hline & L & KJ133456 & KJ133494 & KJ133514 \\
\hline Flavoplaca aff. lutea & ik et al. (2014c); SK-841 & KJ133457 & KJ133495 & KJ133515 \\
\hline Flavoplaca aff. lutea & Kondratyuk et al. (2014c); SK-843 & KJ133458 & KJ133496 & KJ133516 \\
\hline Follmannia orthoclada & Arup et al. $(2013 a)$ & КС179291 & & \\
\hline
\end{tabular}




\begin{tabular}{|c|c|c|c|c|}
\hline Species name & References / voucher details & ITS & LSU & $\mathrm{mtSSU}$ \\
\hline Fominiella skii & Vondrák et al. (2012), holotype & HM582191 & & \\
\hline Fominiella skii & Vondrák et al. (2012) & HM582188 & & \\
\hline Fominiella skii & Vondrák et al. (2012) & HM582194 & & \\
\hline Fominiella skii & Vondrák et al. (2012) & HM582190 & & \\
\hline Fominiella tenerifensis & $\begin{array}{l}\text { *SK-D19, Spain: Tenerife, 15.01.2009, } \\
\text { Kondratyuk, S. Y. } 20916 \text { KW-L, holotype }\end{array}$ & & KY614447 & KY614478 \\
\hline Franwilsia bastowii & Kondratyuk et al. (2014a); SK-810 & KJ021324 & KJ021257 & KJ021284 \\
\hline Franwilsia kilcundaensis & Kondratyuk et al. (2014a); SK-920 & KJ021326 & KJ021259 & KJ021286 \\
\hline Franwilsia renatae & Kondratyuk et al. (2014a); SK-235 & KJ021329 & & KJ021289 \\
\hline Fulgensia cranfieldii & Kondratyuk et al. (2014a); SK-983 & KJ021333 & KJ021262 & KJ021292 \\
\hline Fulgensia fulgens & Kondratyuk et al. (2014a); SK-735 & KJ021335 & & KJ021295 \\
\hline Fulgensia poeltii & Gaya et al. (2008) & EU639586 & & \\
\hline Fulgogasparrea decipioides & Kondratyuk et al. (2013b); SK-689 & KF264644 & & KF264695 \\
\hline Fulgogasparrea decipioides & Kondratyuk et al. (2013b); SK-691 & KF264643 & & KF264694 \\
\hline Fulgogasparrea decipioides & Arup et al. (2013a) & КС179333 & KC179269 & KC179608 \\
\hline Gallowayella borealis & Arup et al. (2013a) & & KC179278 & KC179617 \\
\hline Gallowayella fulva & Fedorenko et al. (2009); FNM-035 & EU681352 & & \\
\hline Gallowayella hasseana & Arup et al. (2013a) & & KC179280 & KC179619 \\
\hline Gallowayella poeltii & Fedorenko et al. (2009); FNM-111 & EU681345 & & \\
\hline Gallowayella poeltii & Arup et al. (2013a) & & KC179282 & KC179622 \\
\hline Gallowayella poeltii & Gaya et al. (2012) & & JQ301583 & \\
\hline Gallowayella weberi & Fedorenko et al. (2009); FNM-031 & EU681345 & & \\
\hline
\end{tabular}

Gintarasiella aggregata

Gintarasiella aggregata

\section{Gintarasiella aggregata}

Golubkovia trachyphylla Golubkovia trachyphylla Golubkovia trachyphylla Golubkovia trachyphylla Gondwania cribrosa Gondwania regalis Gondwania sejongensis

Gondwania sejongensis Gyalolechia aurea Gyalolechia canariensis Gyalolechia canariensis Haloplaca sorediella Haloplaca suaedae Hanstrassia jaeseounhuri

Hanstrassia jaeseounhurii

Hanstrassia lenae

Hanstrassia lenae

Hanstrassia aff. lenae

Hanstrassia aff. lenae
*SK-A84, S Australia, 17.09.2012, Kantvilas, G. 476/12 HO 567239 - holotype *SK-A85, Australia: South Australia, 17.09.2012, Kantvilas, G. 476/12 KW-L ex HO 567239 - isotype

*SK-A86, Australia: South Australia, 17.09.2012 Kantvilas, G. 476/12 KW-L ex HO 567239 - isotype

Kondratyuk et al. (2014c); SK-491

Kondratyuk et al. (2014c); SK-492

Kondratyuk et al. (2014c); SK-486

Arup et al. (2013a)

Arup et al. (2013a)

Arup et al. (2013a)

Kondratyuk et al. (2014c); SK-748, holotype

Kondratyuk et al. (2014c); SK-758

Arup et al. (2013a)

Gaya et al. (2008)

Kondratyuk et al. (2014a); SK-583

Arup et al. (2013a)

Vondrák et al. (unpubl.)

KY614390 KY614448 KY614479

KY614391 KY614449 KY614480

KY614392 KY614450 KY614481 KJ133460

KJ133459 KJ133524

KC179283 KC179283 KC179623

KC179102 KC179192 KC179526

KC179103 KC179193 KC179527

KJ133465 KJ133531

KJ133467 KJ133532

KC179434 KC179196 KC179530

EU639587

KJ021332

KC179293

HM582197 J.-S. (CH-160016) KoLRI 41972, holotype KY614399 J.-S. (CH-160016) KoLRI 41972, holotype KY614399

*China, 17.06.2016, Park, Ch.-N., Hur, J.-S. (CH-160015) KoLRI 41971, isotype Søchting and Figueras (2007)

KY614400

DQ888717

Arup et al. (2013a)

KC179442

*SK-655, Russia, 16.09.2011,

Yakovchenko, L. S., T-461 KoLRI KY614401

KY614482

*SK-654, Russia, 16.09.2011,

Yakovchenko, L. S., T-458 KoLRI

KY614402

KY614483 


\begin{tabular}{|c|c|c|c|c|}
\hline Species name & References / voucher details & ITS & LSU & $\mathrm{mtSSU}$ \\
\hline Harusavskia & *SK-996, Chile, 12.12.2012, Oh, S.-O., Hur, & & & \\
\hline elenkinianoides & J.-S., CL-120324 KoLRI 14493, holotype & KY614403 & KY614451 & KY614484 \\
\hline Harusavskia & *SK-997, Chile, 12.12.2012, Oh, S.-O., Hur, & & & \\
\hline elenkinianoides & J.-S., CL-120324 KoLRI 14493, holotype & KY614404 & KY614452 & KY614485 \\
\hline Harusavskia & *SK-269, Chile, 12.12.2012, Oh, S.-O., Hur, & & & \\
\hline elenkinianoides & J.-S., CL-120324 KoLRI 14493 holotype & KY614405 & KY614453 & KY614486 \\
\hline geria rosmarieae & $\begin{array}{l}\text { Eichenberger et al. (unpubl., as Xantho- } \\
\text { mendoza weberi) }\end{array}$ & AM697873 & & \\
\hline Honeggeria rosmarieae & $\begin{array}{l}\text { Arup et al. }(2013 a \text {, as Xanthomendoza } \\
\text { weberi) }\end{array}$ & КС179145 & KC179285 & KC179625 \\
\hline Huneckia pollinii & Kondratyuk et al. (2014a); SK-3206 & KJ021336 & KJ021265 & KJ021296 \\
\hline Huneckia pollinii & 014a); SK-870 & KJ021337 & KJ021266 & KJ021297 \\
\hline Huneckia rheinigera & Kondratyuk et al. (2014a); SK-3204 & KJ021222 & & \\
\hline Huriella loekoesiana & $\begin{array}{l}\text { Kondratyuk et al. (2014c, as Squamulea } \\
\text { subsoluta); SK-694 }\end{array}$ & KJ133481 & & \\
\hline Huriella loekoesiana & $\begin{array}{l}\text { *South Korea, 24.04.2012, Jayalal, U. } \\
\text { et al. (120433), KoLRI 15423 }\end{array}$ & KY614406 & & KY614487 \\
\hline Huriella loekoesiana & $\begin{array}{l}\text { *South Korea, 28.06.2013, Oh, S.-O. et } \\
\text { al. (130672), KoLRI } 19017\end{array}$ & KY614407 & & KY614488 \\
\hline Huriella loekoesiana & $\begin{array}{l}\text { *South Korea, 10.07.2016, Kondratyuk, } \\
\text { S. Y., Lőkös, L. (161904), KoLRI } 40141\end{array}$ & KY614408 & & \\
\hline Huriella loekoesiana & $\begin{array}{l}\text { *South Korea, 11.07.2016, Kondratyuk, } \\
\text { S.Y., Lőkös, L. (161998), KoLRI } 40236\end{array}$ & KY614409 & & \\
\hline Huriella loekoesiana & $\begin{array}{l}\text { *South Korea, 11.07.2016, Kondratyuk, } \\
\text { S. Y., Lőkös, L. (162000), KoLRI } 40238\end{array}$ & KY6 & & \\
\hline Igneoplaca ignea & Arup et al. $(2013 a)$ & KC179382 & KC179219 & KC179555 \\
\hline Igneop & Arup and Grube (1999) & AF353950 & & \\
\hline Ikaeria aurantiellina & $\begin{array}{l}\text { *SK-538, Spain, Tenerife, 15.01.2009, } \\
\text { Kondratyuk, S. Y. 20916, KW-L }\end{array}$ & KY614411 & & KY614490 \\
\hline Ikaeria aurantiellina & $\begin{array}{l}\text { *SK-552, Spain, Tenerife, 15.01.2009, } \\
\text { Kondratyuk, S. Y. 20916, KW-L }\end{array}$ & KY614412 & & KY614491 \\
\hline Ikaeria aurantiellina & $\begin{array}{l}\text { *SK-D29, Spain, Tenerife, 15.01.2009, } \\
\text { Kondratyuk S. Y. 20916, KW-L }\end{array}$ & KY614413 & & KY614492 \\
\hline Ikaeria aurantiellina & $\begin{array}{l}\text { *SK-D23, Spain, Tenerife, 15.01.2009, } \\
\text { Kondratyuk S. Y. 20916, KW-L }\end{array}$ & KY61 & & KY614493 \\
\hline Ioplac & Gaya & JQ301672 & & \\
\hline Jackeli & l. (2009); FNM-064 & & & EU680870 \\
\hline Jackelix & rup et al. (2013) & КC179351 & & KC179180 \\
\hline ectula & & KC1 & KC179182 & KC179517 \\
\hline Jackel & 1 & EU68 & & EU680877 \\
\hline Jasonht & 15c); KoLRI 120454 & KT220196 & KT220205 & KT220214 \\
\hline Jasonhuria bogilana & k et al. (2015c); KoLRI 120469 & KT220197 & KT220206 & KT220215 \\
\hline Jasonhuria bogilana & & KT220198 & KT220207 & KT220216 \\
\hline Jasonhuria bogilana & Kondratyuk et al. (2015c); KoLRI 120647 & KT220199 & KT220208 & KT220217 \\
\hline Jesmurraya novozelandica & $\begin{array}{l}\text { Arup et al. (2013a) (sub Xanthomendoza } \\
\text { novozelandica) }\end{array}$ & КC179140 & & KC179621 \\
\hline Jesmurr & Fedorenko et al. (2009); FNM-114 & EU681347 & & \\
\hline & $\begin{array}{l}\text { *SK-C82, New Zealand, Otago, } 17.04 . \\
\text { 2010, D. J. Galloway 6000, KW-L }\end{array}$ & & KY614454 & KY614489 \\
\hline Josefpoeltia sorediosa & Kondratyuk et al. (2013b); SK-991 & KF264645 & KF264673 & KF264696 \\
\hline Kaernefia kaernefeltii & al. $(2013 b) ;$ SK-921 & KF264652 & KF264680 & KF264703 \\
\hline aurantia & & КС179470 & KC179261 & KC179600 \\
\hline Klaud & & EU639602 & & \\
\hline Klauderuiella aurantia & Gaya et al. (2015) & & & KT291479 \\
\hline
\end{tabular}




\begin{tabular}{|c|c|c|c|c|}
\hline \multirow{2}{*}{$\begin{array}{l}\text { Species name } \\
\text { Klauderuiella flavescens }\end{array}$} & References / voucher details & ITS & LSU & $\mathrm{mtSSU}$ \\
\hline & $\begin{array}{l}\text { *SK-561, Spain, Tenerife, 16.01.2009, } \\
\text { Kondratyuk, S. Y. 20925, KW-L }\end{array}$ & KY614416 & & KY614495 \\
\hline Klauderuiella thallincola & $\begin{array}{l}\text { `SK-527, 18.08.1997, Kärnefelt, } \\
\text { I. 970901 LD } 1076480\end{array}$ & KY614415 & & KY614494 \\
\hline Langeottia ottolangei & Kondratyuk et al. (2014c); SK-239 & KJ133468 & KJ133497 & KJ133533 \\
\hline Langeottia ottolangei & Kondratyuk et al. (2014c); SK-240 & KJ133469 & KJ133498 & KJ133534 \\
\hline Langeottia ottolangei & Kondratyuk et al. (2014c); SK-264 & KJ133470 & KJ133499 & KJ133535 \\
\hline Langeottia ottolangei & Kondratyuk et al. (2014c); SK-265 & KJ133471 & KJ133500 & KJ133536 \\
\hline Laundonia flavovirescens & $\begin{array}{l}\text { *SK-657, Russia, 16.09.2011, Yakov- } \\
\text { chenko, L. S., T-461, KoLRI }\end{array}$ & KY614417 & & KY614496 \\
\hline Laundonia flavovirescens & Arup and Grube (1999) & AF353966 & & \\
\hline Laundonia flavovirescens & Arup et al. (2013a) & & KC179198 & KC179532 \\
\hline Laundonia persimilis & Arup et al. (2013a) & KC179444 & & \\
\hline Laundonia persimilis & Vondrák et al. (unpubl.) & KT804978 & & \\
\hline Laundonia persimilis & Vondrák et al. (unpubl.) & KT804979 & & \\
\hline Lazarenkoella zoroasteriorum & Kondratyuk et al. (2015d); SK-A45 & KT456215 & KT456230 & KT456245 \\
\hline Lazarenkoella zoroasteriorum & Kondratyuk et al. (2015d); SK-A51 & KT456216 & KT456231 & KT456246 \\
\hline Lazarenkoella zoroasteriorum & Kondratyuk et al. (2015d); SK A55 & KT456217 & KT456232 & KT456247 \\
\hline & $\begin{array}{l}\text { *SK A36, Russia, 03.08.2013, } \\
\text { Kondratyuk, S. Y., 213R3 130130 KoLRI }\end{array}$ & & & KY614497 \\
\hline Lazarenkoiopsis ussuriensis & $\begin{array}{l}\text { *SK A37, Russia, 03.08.2013, } \\
\text { Kondratyuk, S. Y., 213R3 130130 KoLRI } \\
\text { *SK D22, Russia, 03.08.2013, }\end{array}$ & KY614418 & KY614455 & KY614498 \\
\hline & Kondratyuk, S. Y., 213R3 130130 KoLRI & KY614419 & KY614456 & KY614499 \\
\hline Leproplaca obliterans & Arup et al. $(2013 a)$ & КC179449 & & KC179207 \\
\hline tholyta & Arup & КC179451 & KC179208 & KC179542 \\
\hline aca xantholyta & (2012) & JQ301670 & & JQ301565 \\
\hline Loekoesia austrocoreana & Kondratyuk et al.(2015c); KoLRI 120511 & KT220200 & KT220209 & KT220218 \\
\hline Loekoesia austrocoreana & Kondratyuk et al.(2015c); KoLRI 120523 & KT220201 & KT220210 & KT220219 \\
\hline Loekoes & ); SK-261 & KT220202 & KT220211 & KT220220 \\
\hline Marchantiana kalbiorum & ; SK-939 & KJ021225 & KJ023183 & KJ021300 \\
\hline Marchantiana occidentalis & Kondratyuk et al. (2014a); SK-981 & KJ021227 & KJ021268 & KJ021303 \\
\hline Marchantiana occidentalis & Kondratyuk et al. (2014a); SK-982 & KJ021228 & KJ021269 & KJ021304 \\
\hline Martinjahnsia r & Marti & AF101285 & & \\
\hline Martinjahnsia resendei & tal. $(2013 a)$ & & KC179290 & KC179630 \\
\hline Massjukiella polycarpa & Arup et al. (2013a) & КC179389 & KC179222 & \\
\hline Massjukiella polycarpa & nko et al. (2012); FNM-172 & & & JN984146 \\
\hline Massjukiella polycarpa & o e et al. (2009); FNM-173 & EU681333 & & EU680919 \\
\hline ‘Caloplaca' allochroa' & l. (2011) & HQ415800 & & \\
\hline Mikhtomia gordejevii & Kondratyuk et al. (2014a); SK-80515 & KJ021231 & & KJ021307 \\
\hline Mikhtomia gordejevii & $\begin{array}{l}\text { *South Korea, 06.07.2012, Kondratyuk, } \\
\text { S. Y. (121959), KoLRI } 16914\end{array}$ & KY614420 & KY614457 & \\
\hline Mikhtomia gordejevii & $\begin{array}{l}\text { *South Korea, 01.06.2012, collector } \\
\text { unmentioned (120924), KoLRI } 15954\end{array}$ & KY614421 & KY614458 & \\
\hline Mikhtomia gordejevii & Kondratyuk et al.(2014a); SK-80646 & KJ021232 & & KJ021308 \\
\hline Mikhtomia multicolor & Kondratyuk et al. (2014a); SK-A14 & & KJ021272 & \\
\hline Mikhtomia multicolor & $\begin{array}{l}\text { *South Korea, 28.06.2013, Oh, S.-O. } \\
\text { et al. (130601), KoLRI } 18946\end{array}$ & KY614422 & KY614459 & \\
\hline Mikhtomia multicolor & $\begin{array}{l}\text { *South Korea, } 29.08 .2004 \text {, Hur, J.-S. } \\
\text { (40900), KoLRI } 001689\end{array}$ & KY614423 & KY614460 & \\
\hline Mikhtomia multicolor & $\begin{array}{l}\text { *SK A19, South Korea, 11.05.2012, } \\
\text { Oh. S.-O. (120832). KoLRI } 15829\end{array}$ & KY614424 & & \\
\hline Mikhtomia multicolor & $\begin{array}{l}\text { *South Korea, 28.06.2013, Oh, S.-O. } \\
\text { et al. (130604), KoLRI } 18949\end{array}$ & & KY614461 & \\
\hline
\end{tabular}




\begin{tabular}{|c|c|c|c|c|}
\hline \multirow{2}{*}{$\begin{array}{l}\text { Species name } \\
\text { Mikhtomia subflavorubencens }\end{array}$} & References / voucher details & ITS & LSU & $\mathrm{mtSSU}$ \\
\hline & $\begin{array}{l}\text { Kondratyuk et al. (2014a as M. oxnerii); } \\
\text { SK-90117 }\end{array}$ & KJ021233 & & KJ021311 \\
\hline Mikhtomia subflavorubencens & $\begin{array}{l}\text { Kondratyuk et al.(2014a as M. oxnerii); } \\
\text { SK-90755 }\end{array}$ & KJ021234 & & KJ021312 \\
\hline Neobrownliella brownlieae & Kondratyuk et al. (2013b); SK-831 & KF264626 & KF264661 & KF264687 \\
\hline Neobrownliella brownlieae & Kondratyuk et al. (2013b); SK-838 & KF264627 & KF264662 & KF264688 \\
\hline Neobrownliella montisfracti & Kondratyuk et al. (2013b); SK-230 & KF264624 & KF264659 & \\
\hline Nevilleiella lateritia & $\begin{array}{l}\text { *SK-878, Australia, 10.01.1999, } \\
\text { Kärnefelt, I. 990904, LD } 1236736\end{array}$ & KY614426 & KY614463 & KY614501 \\
\hline Nevilleiella lateritia & $\begin{array}{l}\text { *SK-261, Australia, 10.01.1999, } \\
\text { Kärnefelt, I. 990904, LD } 1236736\end{array}$ & KY614427 & KY614464 & KY614502 \\
\hline Nevilleiella marchantii & $\begin{array}{l}\text { *SK-D18, Western Australia, 08.01.2004, } \\
\text { Kondratyuk, S. Y. 20444, KW-L - isotype }\end{array}$ & KY614425 & KY614462 & KY614500 \\
\hline Niorma chrysophthalma & Eichenberger et al. (unpubl.) & AM292836 & & \\
\hline Niorma chrysophthalma & Gaya et al. (2012) & & JQ301576 & JQ301518 \\
\hline Olegblumia demissa & Kondratyuk et al. (2015c); SK-C65 & KT220203 & KT22 & KT220221 \\
\hline Opeltia arizonica & Arup et al. $(2013 a)$ & KC179433 & KC179195 & KC179529 \\
\hline Opeltia juniperina & $\begin{array}{l}\text { *SK-D10, China, 01.08.2013, Oh, S.-O., } \\
\text { Hur, J.-S., CH 130112 KoLRI }\end{array}$ & KY614429 & & KY614504 \\
\hline Opeltia juniperina & Vondrák and Halici (unpubl.) & JN813383 & & \\
\hline Opeltia juniperina & Joshi et al. (2011) & HQ644199 & & \\
\hline Opeltia neobaltistanica & $\begin{array}{l}\text { *SK-D09, China, 01.08.2013, Oh, S.-O., } \\
\text { Hur, J.-S., CH 130098 KoLRI }\end{array}$ & KY614428 & & KY6 \\
\hline Drie & Kondratyuk et al. (2014c); SK-721 & & & KJ133540 \\
\hline Orientophila loekoesii & Kondratyuk et al. (2014c); SK-692 & & & KJ133539 \\
\hline Orientophila loekoesii & Kondratyuk et al. (2014c); SK-691 & & & KJ133538 \\
\hline Orientophila loekoesii & ket al. (2014c); SK-690 & & & KJ133537 \\
\hline Orientophila subscopularis & $2013 a)$ & КС179375 & & КС179546 \\
\hline Orientophila subscopularis & tyuk et al. (2014c); SK-727 & KJ133476 & & \\
\hline Orientophila subscopularis & Kondratyuk et al. (2014c); SK-692 & KJ133475 & & \\
\hline Orientophila subscopularis & Kondratyuk et al. (2014c); SK-717 & KJ133474 & & \\
\hline
\end{tabular}

Ovealmbornia reginae

Arup et al. (2013a, as Ovealmbornia bonae-spei) (see Kondratyuk et al. 2015f)

Ovealmbornia volkmarwirthii Arup et al. (2013a, as Ovealmbornia bonae-spei) (see Kondratyuk et al. 2015f)

Ovealmbornia volkmarwirthii Kondratyuk et al. (2014c; 2015f); SK-241

Ovealmbornia volkmarwirthii Kondratyuk et al. (2014c; 2015f); SK-242

Ovealmbornia sp.

Fedorenko et al. (2009, as Ovealmbornia bonae-spei); FNM-099 (see Kondratyuk et al. 2015f)

Oxneria alfredii

Oxneria huculica

Fedorenko et al. (2009); FNM-152

KC179181 KC179516

KC179353

KJ133477 KJ133501 KJ133541

KJ133478 KJ133502 KJ133542

EU681319 $\quad$ EU680902

EU681345 EU680933

Fedorenko et al. (2009, as Oxneria fallax); FNM-199

Oxneria huculica

Oxneria huculica

Gaya et al. (2012, as Oxneria fallax)

EU681346

Arup et al. (2013, as Xanthomendoza fallax)

Oxneria huculica

Fedorenko et al. (2009, as Oxneria fallax); FNM-022

Oxneriopsis oxneri

Oxneriopsis oxneri

Arup et al. (2013, as Caloplaca oxneri)

*SK-695, Russia, 17.09.2011

Oxneriopsis aff. oxneri

Kondratyuk, S. Y. 21138, KW-L
*SK-771, Russia, 17.09.2011

Kondratyuk, S. Y. 21138, KW-L

Oxneriopsis yeosuensis

*South Korea, 24.03.2007, Hur, J.-S. (70080), KoLRI 007067

JQ301580

KC179279

EU680931

KC179443

KY614430

KY614505

KY614431

KY614506

KY614432 KY614465 KY614507 


\begin{tabular}{|c|c|c|c|c|}
\hline Species name & References / voucher details & ITS & LSU & $\mathrm{mtSSU}$ \\
\hline Oxneriopsis yeosuensis & $\begin{array}{l}\text { *South Korea, 26.04.2012, Jayalal, U. } \\
\text { et al. (120357), KoLRI 15346 }\end{array}$ & KY614433 & KY614466 & KY614508 \\
\hline Oxneriopsis yeosuensis & $\begin{array}{l}\text { *South Korea, 26.04.2012, Jayalal, U. } \\
\text { et al. (120336), KoLRI 15325 }\end{array}$ & KY614434 & KY614467 & KY614509 \\
\hline Pachypeltis castellana & Arup et al. $(2013 a)$ & KC179105 & & КC179547 \\
\hline Parvoplaca tiroliensis & Arup et al. (2013a) & KC179116 & KC179216 & KC179552 \\
\hline Polycauliona coralloides & Arup et al. (2013a) & KC179380 & KC179218 & KC179554 \\
\hline Polycauliona coralloides & Gaya et al. (2015) & KT291451 & KT291539 & KT291485 \\
\hline Pyrenodesmia alociza & Kondratyuk et al. (2014a); SK-747 & KJ021239 & & KJ021313 \\
\hline Pyrenodesmia chalybaea & Gaya et al. (2012) & JQ301550 & & \\
\hline Pyrenodesmia teicholyta & Vondrák et al. (2012) & JN641791 & & \\
\hline Pyrenodesmia teicholyta & Arup et al. (2013a) & & KC179176 & \\
\hline Pyrenodesmia variabilis & Gaya et al. (2003) & AY233224 & & \\
\hline
\end{tabular}

Raesaeneniana maulensis

Raesaeneniana maulensis Rufoplaca scotoplaca Rusavskia dasanensis Rusavskia elegans Rusavskia elegans Rusavskia sorediata Rusavskia sorediata Scutaria andina Scythioria phlogina Scythioria phlogina Scythioria phlogina Seirophora californica Seirophora lacunosa Seirophora stenophylla Seirophora villosa

\section{Seirophora villosa}

Seirophora villosa Shackletonia hertelii Shackletonia sauronii Sirenophila cliffwetmorei

'Sirenophila' eos 'Sirenophila' eos 'Sirenophila' eos Sirenophila gintarasii Sirenophila gintarasii

'Sirenophila' maccarthyi Solitaria chrysophthalma

Squamulea squamosa Squamulea subsoluta Squamulea subsoluta Squamulea subsoluta Stellarangia elegantissima Streimanniella kalbiorum

Streimanniella michelagoensis Kondratyuk et al. (2014a); SK-971
Kondratyuk et al. (2015d); SK-993, holotype

Kondratyuk et al. (2014a); SK-994

Arup et al. (2013a)

Kondratyuk et al. (2015e); SK-702

Fedorenko et al. (2009); FNM-019

Arup et al. (2013a)

Fedorenko et al. (2009); FNM-046, Finland EU681335

Arup et al. (2013a)

Arup et al. (2013a)

Arup (2006) (sub Caloplaca phlogina)

Arup et al. (2013a, as Polycauliona phlogina)

Vondrák et al. (2010, as Caloplaca scythica)

Arup et al. (2013a)

Kondratyuk et al. (2015c); SK-B07

Arup et al. (2013a)

*SK-D27, Italy, 01.04.2015, Ravera, S. (specimens 1), KW-L

*SK-D16, Morocco, 25.03.2014,

Guttová, A., KW-L ex BRA

Martin and Winka (2000)

Arup et al. (2013a)

Arup et al. (2013a)

*SK-A93, Australia, 15.09.2012,

Kantvilas, G., 446/12 KW-L ex HO

Kondratyuk et al. (2013b); SK-912

Arup et al. (2013a)

Gaya et al. (2015)

Arup et al. (2013a)

*SK-D17, Australia, 19.01.2004,

Kondratyuk, S. Y., KW-L - isotype

Arup et al. (2013a)

*SK-D20, Sweden, 27.01.2012,

Arup, U., L 05051 LD 1109837

Arup et al. (2013a)

Arup (2006)

Arup et al. (2013a)

Kondratyuk et al. (2014c); SK-670

Arup et al. (2013a)

Kondratyuk et al. (2014a); SK-939

\author{
KT456218 KT456233 KT456248 \\ KJ023182 KJ023184 \\ KC179457 KC179235 KC179573 \\ KU056846 KU043372 \\ EU681336 EU680921 \\ KC179238 KC179576 \\ EU680920 \\ KC179239 \\ KC179298 KC179242 KC179581 \\ DQ173234 \\ GU080302 \\ KC179221 KC179557 \\ KC179643 \\ KT220204 KT220213 KT220222 \\ KC179647
}

KY614435 KY614468 KY614510

KY614436 KY614469 KY614511

AF098407

KC179118 KC179579

KC179120 KC179241 KC179580

KY614438 KY614471 KY614513

KF264656

KC179300 KC179246 KC179585

KT291455 KT291542 KT291489

KC179302

KY614437 KY614470 KY614512 KC179304 KC179249 KC179588

KY614439 KY614514

KC179125 KC179252 KC179591

DQ173238

KJ133480

KC179253 KC179592

KC179310 KC179254 KC179593

KJ021225 KJ023183 KJ021300

KJ021226 KJ023185 KJ021301 


\begin{tabular}{|c|c|c|c|c|}
\hline Species name & References / voucher details & ITS & LSU & $\mathrm{mtSSU}$ \\
\hline Streimanniella seppeltii & Kondratyuk et al. (2014a); SK-855 & KJ021229 & KJ023186 & KJ021305 \\
\hline Tarasginia whinrayi & Kondratyuk et al. (2015d); SK-A95 & KT456220 & KT456235 & KT456250 \\
\hline Tarasginia whinrayi & ondratyuk et al. (2015d); SK-B02 & KT456221 & KT456236 & KT456251 \\
\hline Tassiloa digitaurea & ondratyuk et al. (2015a); SK-A34 & КР096222 & & KP096224 \\
\hline Tayloriella erythrosticta & ondratyuk et al. (2015d); SK-817 & KT456222 & KT456237 & KT456252 \\
\hline Tayloriella erythrosticta & ondratyuk et al. (2015d); SK-814 & KT456223 & KT456238 & KT456253 \\
\hline Tayloriella erythrosticta & ondratyuk et al. (2015d) SK-819 & KT456224 & KT456239 & KT456254 \\
\hline Teloschistes flavicans & dorenko et al. $(2009,2012) ;$ FNM-139 & EU681363 & & EU680955 \\
\hline Teloschistes flavicans & Arup et al. (2013a) & КC179317 & KC179255 & KC179594 \\
\hline Teloschistes flavicans & Fedorenko et al. (2009, 2012); FNM-218 & EU681362 & & JN984150 \\
\hline Teloschistes flavicans & Gaya et al. (2012) & & JQ301578 & \\
\hline Teloschistopsis bonae-spei & & KC179322 & KC179257 & KC179596 \\
\hline chrysocarpoides & Arup & $\mathrm{KC} 1$ & & \\
\hline Teloschistopsis eudoxa & Arup & KC179324 & KC179258 & KC179597 \\
\hline Thelliana pseudokiamae & 1. $(2015 d) ;$ SK-925 & KT456225 & KT456240 & KT456255 \\
\hline Thelli & 926 & KT4 & KT456241 & KT456256 \\
\hline Teuvoahtiana altoandina & Arup et al. (2013a, as 'Caloplaca' altoandina) & KC17 & KC179170 & KC179503 \\
\hline euvoahtiana fernandeziana & $\begin{array}{l}\text { *SK-995, Chile, 27.01.2012, Wang, X. Y., } \\
\text { Oh, S.-O., Hur, J.-S., CL-120121 }\end{array}$ & & & \\
\hline & & KY614440 & & KY614515 \\
\hline tgulosa & ${ }^{*} \mathrm{~S}$ & & & \\
\hline & & KY614441 & KY614472 & KY614516 \\
\hline Teuvoahtiana rugulosa & *SK & & & \\
\hline & & KY614442 & KY614473 & KY614517 \\
\hline 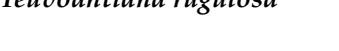 & S.-O., H & KY614443 & KY614474 & KY614518 \\
\hline Tomnashia ludificans & Arup et al. (2013a, as Polycauliona & & & \\
\hline & & KC17 & & \\
\hline Tomnashia luteominia & Arup & & & \\
\hline & & KC179387 & KC179220 & KC179556 \\
\hline Tomnashia nashii & $\begin{array}{l}\text { Vondrák et al. (unpubl., as Caloplaca } \\
\text { nashii) }\end{array}$ & & & \\
\hline & et al. (2013a, as Polycauliona rosei) & KC1? & KC179223 & КC179559 \\
\hline phinea & & KC179468 & KC179259 & KC179598 \\
\hline inea & & EU639595 & & \\
\hline & & & JQ301548 & \\
\hline phila & & & JQ301560 & \\
\hline & & & KJ021276 & KJ023192 \\
\hline & & & & KJ023191 \\
\hline dratovii & 84 & KJ02 & KJ021274 & KJ023190 \\
\hline & & JN81 & & \\
\hline lacrocarpa & (1999) & AF353956 & & \\
\hline & & & & KC179605 \\
\hline Ver & & KC179404 & KC179223 & \\
\hline culifera & & EU639624 & & \\
\hline Verrucoplaca verruculifera & Gaya et al. (2012) & & JQ301564 & JQ301500 \\
\hline & & & KC179266 & KC179606 \\
\hline & & KF26 & & KF264710 \\
\hline & l. $(2013 b) ;$ SK-536 & KF264658 & & KF264711 \\
\hline Wetmoreana texana & Arup et al. (2013a) & KC179337 & KC179273 & KC179612 \\
\hline Xanthaptychia aurantiaca & Arup et al. (2013a, as Seirophora aurantiaca) & КС179461 & & \\
\hline Xanthaptychia blumii & $\begin{array}{l}\text { Kondratyuk et al. (2015d, as Seirophora } \\
\text { blumii); SK-A65 }\end{array}$ & KT456219 & KT456234 & KT45624 \\
\hline
\end{tabular}




\begin{tabular}{|c|c|c|c|c|}
\hline Species name & References / voucher details & ITS & LSU & $\mathrm{mtSSU}$ \\
\hline Xanthaptychia contortuplicata & $\begin{array}{l}\text { Arup et al. (2013a, as Seirophora } \\
\text { contortuplicata) }\end{array}$ & KC179464 & & \\
\hline Xanthaptychia contortuplicata & $\begin{array}{l}\text { Gaya et al. }(2015, \text { as Seirophora } \\
\text { contortuplicata) }\end{array}$ & KT291471 & & KT291522 \\
\hline Xanthaptychia contortuplicata & $\begin{array}{l}\text { Kondratyuk et al. (2014a, as Seirophora } \\
\text { contortuplicata); SK-775 }\end{array}$ & & & KJ021316 \\
\hline Xanthaptychia orientalis & $\begin{array}{l}\text { Fedorenko et al. ( } 2009 \text {, as Seirophora } \\
\text { orientalis); FNM-153 }\end{array}$ & EU681287 & & \\
\hline Xanthaptychia orientalis & $\begin{array}{l}\text { Kondratyuk et al. (2014a, as Seirophora } \\
\text { orientalis); SK-756 }\end{array}$ & KJ021241 & & \\
\hline Xanthaptychia orientalis & $\begin{array}{l}\text { Kondratyuk et al. ( } 2014 a \text {, as Seirophora } \\
\text { orientalis); SK-755 }\end{array}$ & KJ021240 & & KJ023189 \\
\hline $\begin{array}{l}\text { Xanthocarpia } \\
\text { jerramungupensis }\end{array}$ & Kondratyuk et al. (2014c); SK-142 & KJ133484 & KJ133503 & KJ133543 \\
\hline $\begin{array}{l}\text { Xanthocarpia } \\
\text { jerramungupensis }\end{array}$ & Kondratyuk et al. (2014c); SK-917 & KJ133485 & KJ133504 & KJ133544 \\
\hline $\begin{array}{l}\text { Xanthocarpia cf. } \\
\text { jerramungupensis }\end{array}$ & Kondratyuk et al. (2014c); SK-247 & KJ133486 & KJ133505 & KJ133545 \\
\hline Xanthocarpia ochracea & ket al. (2014c); SK-637 & KJ133483 & & \\
\hline Xanthocarpia ochracea & Arup & КC179132 & KC179277 & КC179617 \\
\hline Xanthokarrooa karrooensis & Fedorenko et al. (2009); FNM-066 & EU681320 & & EU680903 \\
\hline Xanthomendoza mendozae & Fedorenko et al. (2009); FNM-215 & EU681349 & & \\
\hline Xanthomendoza & o et al. (2009); FNM-065 & & & EU680938 \\
\hline Xanthomendoza & o et al. (2009); FNM-069 & & & EU680939 \\
\hline Xanthomendoza mendozae & Arup et al. (2013a) & KC179138 & КC179281 & KC179620 \\
\hline Xanthopeltis rupicola & Arup et al. (2013a) & КС179146 & KC179286 & KC179626 \\
\hline Xanthopeltis rupicola & Gaya & & KT291570 & KT291530 \\
\hline Xanthoria parietina & Fedorenko et al. (2009, 2012); FNM-177 & EU681289 & & EU680868 \\
\hline Xanthoria parietina & Gaya et al. (2012) & & JQ301589 & \\
\hline Xanthoria parietina & Fedorenko et al. (2009, 2012); FNM-177 & EU681289 & & EU680868 \\
\hline Xanthoria parietina & 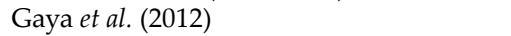 & & JQ301589 & \\
\hline Xanthoria parietina & ko et al. $(2009,2012)$; FNM-017 & EU681288 & EU680867 & \\
\hline Xanthoria parietina & Lutzoni et al. (2001) & & AF356687 & \\
\hline Yoshimuria cerussata & Kondratyuk et al. (2014a); SK-768 & KJ021248 & & \\
\hline Yoshimuria galbina & uk et al. (2014a); SK-704 & & & KJ023197 \\
\hline Yoshimuria spodoplaca & ik et al. (2014a); SK-725 & KJ021249 & & KJ023194 \\
\hline Zeroviella coreana & Kondratyuk et al. (2015e); SK-D06 & KU056848 & & KU043373 \\
\hline Zeroviella esfahanensis & & & & KU043374 \\
\hline la papillifera & o et al. (2009); FNM-018 & EU681331 & & EU680927 \\
\hline Zerovie & et al. (2009); FNM-204 & EU681330 & & EU680926 \\
\hline Zeroviella ussurica & Kondratyuk et al. (2015e); SK-D08, isotype & KU056857 & & KU043379 \\
\hline
\end{tabular}

